Faculdade de Economia, Administração, Contabilidade e Ciência da Informação e Documentação - FACE

Curso de Especialização em Desenvolvimento Gerencial

\title{
COMPROMETIMENTO NO TRABALHO DE FUNCIONÁRIOS DO SERVIÇO DE NUTRIÇÃO DO HOSPITAL UNIVERSITÁRIO DE BRASÍLIA
}

Orientadora: Professora Catarina Cecília Odelius 


\title{
COMPROMETIMENTO NO TRABALHO DE FUNCIONÁRIOS DO SERVIÇO DE NUTRIÇÃO DO HOSPITAL UNIVERSITÁRIO DE BRASÍLIA
}

\author{
Monografia apresentada ao Programa de Pós- \\ graduação em Administração da Faculdade de \\ Economia, Administração, Contabilidade e Ciência da \\ Informação e Documentação (FACE), da \\ Universidade de Brasília, como requisito parcial à \\ obtenção do grau de Especialista em \\ Desenvolvimento Gerencial. \\ Orientadora: Profa Dra. Catarina Cecília Odelius
}

Brasília - DF

2007

Clarissa Hoffman Irala e Meg Schwarcz Hoffmann 


\title{
COMPROMETIMENTO NO TRABALHO DE FUNCIONÁRIOS DO SERVIÇO DE NUTRIÇÃO DO HOSPITAL UNIVERSITÁRIO DE BRASÍLIA
}

\begin{abstract}
Monografia apresentada ao Programa de Pósgraduação em Administração da Faculdade de Economia, Administração, Contabilidade e Ciência da Informação e Documentação (FACE), da Universidade de Brasília, como requisito parcial à obtenção do grau de Especialista em Desenvolvimento Gerencial. Orientadora: Profa Dra. Catarina Cecília Odelius
\end{abstract}

BANCA EXAMINADORA 
A aprendizagem é sempre um grande desafio. Por isso, agradecemos a todos que de forma direta ou indireta nos ajudaram e apoiaram e que, de fato, acreditam nessa verdade.

A todos os funcionários do Serviço de Nutrição do HUB que se esforçaram para nos ajudar na pesquisa.

A nossa chefia pelo apoio incondicional.

À FACE e à UNB por investir e acreditar em seus funcionários. 
“... Sempre escrevemos

para recordar a verdade.

Quando inventamos,

é para recordá-la mais exatamente."

Luis Fernando Veríssimo

Em Borges e os orangotangos eternos

\section{RESUMO}

O presente trabalho buscou analisar o grau de comprometimento organizacional, de comprometimento com o trabalho e de comprometimento com a carreira dos funcionários do serviço de nutrição do Hospital Universitário de Brasília -HUB. Baseando-se na idéia de que os interesses entre os indivíduos em seu ambiente de trabalho se manifestam através da manutenção de comportamentos capazes de contribuir na realização do trabalho, avaliou-se os três diferentes focos do comprometimento organizacional, com a carreira e com o trabalho e o desempenho desses funcionários. Os dados foram coletados com a aplicação de questionários validados onde obteve-se, ao todo 46 questionários respondidos, sendo 15 de nutricionistas, 11 de técnicas em nutrição e 20 de outros funcionários que atuam na área (cozinheiros, açougueiros, copeiras, etc). A amostra foi composta na sua maioria por mulheres $(88,9 \%)$ jovens com idade média de 33 anos, metade casada $(53,3 \%)$, com nível superior de escolaridade, tendo como vínculo empregatício uma prevalência de contratados com tempo médio de 3 anos na instituição. O cargo de maior freqüência na pesquisa foi o de nutricionista $(34,1 \%)$. Após a tabulação dos dados coletados, foram realizadas as análises descritivas (distribuição das frequiências, médias e desvios padrão) das variáveis de comprometimento com a organização, trabalho e desempenho individual. Os dados revelaram que há um baixo comprometimento organizacional tanto afetivo quanto instrumental ou normativo com a organização. Separando-se os grupos de nutricionistas, técnicas em nutrição e funcionários, o grupo de nutricionistas foi o mais comprometido afetivamente. A 
inexistência de comprometimento afetivo entre as técnicas em nutrição pode indicar intenção de abandono do emprego. A amostra apresentou comprometimento afetivo com a carreira e comprometimento com o trabalho e o desempenho.

\section{LISTA DE QUADROS}

Quadro 1: Os três componentes mais comuns do comprometimento organizacional 


\section{LISTA DE TABELAS}

Tabela 1- Dados demográficos e funcionais da amostra

Tabela 2 - Médias e desvios padrão dos focos do comprometimento com a organização da amostra

Tabela 3 - Freqüências das respostas, médias e desvios padrão de cada item da escala do comprometimento organizacional referente à amostra.

Tabela 4 - Freqüências das respostas sobre comprometimento organizacional afetivo segundo Meyer, Allen e Smith de acordo com o cargo ocupado.

Tabela 5 - Freqüências das respostas sobre comprometimento organizacional afetivo segundo Mowday de acordo com o cargo ocupado.

Tabela 6- Freqüências das respostas sobre comprometimento organizacional instrumental segundo Meyer, Allen e Smith de acordo com o cargo ocupado. 37

Tabela 7 Freqüências das respostas sobre comprometimento organizacional normativo segundo Meyer, Allen e Smith de acordo com o cargo ocupado.

Tabela 8 - Médias e desvios padrão relacionados aos focos do comprometimento com a carreira da amostra.

Tabela 9- Freqüências das respostas, médias e desvios padrão de cada item da escala do comprometimento com a carreira referente à amostra.

Tabela 10 - Freqüências das respostas sobre os aspectos relacionados ao comprometimento com a carreira de acordo com o cargo ocupado. 
Tabela 11 - Médias e desvios padrão relacionados ao comprometimento com

o trabalho da amostra.

Tabela 12- Freqüências das respostas, médias e desvios padrão de cada item da escala dos aspectos relacionados ao trabalho e desempenho referentes à amostra.

Tabela 13- Freqüências das respostas sobre os aspectos relacionados ao trabalho e desempenho de acordo com o cargo ocupado.

\section{SUMÁRIO}

1 - INTRODUÇÃO

1.1 - Formulação do problema de pesquisa 4

1.2 - Objetivos

1.2.1 - Objetivo Geral

4

1.2.2 - Objetivos Específicos 5

1.3 - Justificativa 5

2 - REFERENCIAL TEÓRICO 8

2.1 - Comprometimento com o trabalho 10

2.2 - Comprometimento organizacional 12

2.2.1 - Abordagem uni e multidimensional 14

2.3 - Comprometimento com a carreira 16

2.4 - Outros enfoques do comprometimento 18

2.4.1 - Comprometimento com o social/grupo 18

2.4.2- Comprometimento ético 20

2.4.3- Outros 20

2.5-Comprometimento e desempenho no trabalho 21

3 - METODOLOGIA $\quad 22$

3.1 - Tipo de pesquisa $\quad 22$

3.2 - Local da pesquisa $\quad 22$

3.3 - Amostra 23

3.4 - Instrumento $\quad 24$

$\begin{array}{ll}3.5 \text { - Procedimentos } & 25\end{array}$

3.5.1- Coleta dos dados do instrumento 25

3.6 - Análise dos dados 26

4 - RESULTADOS E DISCUSSÃO 27

5 - CONCLUSÃO 49

REFERENNCIAS $\quad 52$

APÊNDICE A $\quad 55$

APÊNDICE B 
APÊNDICE C

61

APÊNDICE D

62

APÊNDICE E

64

APÊNDICE F

65

APÊNDICE G

67

APÊNDICE H

69 


\section{1- INTRODUÇÃO}

Nessa virada de milênio, tem sido intenso o esforço empreendido pelas organizações para sobreviver - e quanto a isso, acreditamos que haverá pouca discordância -, como também têm sido enorme o desgaste e o sacrifício impingido ao trabalhador moderno. Se a teoria da administração tem sido pródiga na criação de novas ferramentas de gestão - afinal, surgem novas propostas, antigas propostas são aperfeiçoadas, ou, ainda, cunhadas com um novo rótulo, praticamente todos os dias infelizmente, aquelas que visam proporcionar uma melhor condição de trabalho e satisfação em sua execução - e não apenas, aumento do ganho pecuniário - deixam muito a desejar (VASCONCELOS, 2001).

As conseqüências desse novo quadro geram novas perspectivas de se definir o espaço organizacional como um todo, bem como o mercado e os métodos produtivos. É nesse contexto desafiante que as organizações necessitam identificar e realçar seus pontos fortes, transformando a competitividade, a tecnologia, a flexibilidade e a modernização em questões diretamente relacionadas à sobrevivência, ao mesmo tempo em que devem reestruturar seus pontos fracos. À luz desses esforços, as organizações têm se dedicado a modificações, buscando sempre o sucesso. Ferramentas têm sido desenvolvidas para tal, destacando-se, por exemplo, os programas de Just in Time e de Qualidade Total, usados com muita freqüência e que contam com ampla literatura disponível (BASTOS; BORGES-ANDRADE, 2002). Em especial, os estilos de gerenciar as relações sociais e de trabalho no interior das organizações têm se modificado com vistas a superar o modelo tradicional e burocrático.

Bastos e Borges-Andrade (2002) afirmam que para que as mudanças processadas obtenham os resultados almejados torna-se imprescindível alinhá-las dentro de um processo participativo no contexto da organização, afirmando dessa forma a importância do componente humano das organizações. É importante destacar que há o pressuposto de que o comprometimento da força de trabalho é um requisito fundamental para o sucesso das transformações, já que flexibilidade requer responsabilidade individual e co-responsabilidade entre indivíduos e equipes. E, que os estudos desenvolvidos até então sugerem que elevado comprometimento não é um subproduto natural dos novos modelos organizacionais. Há forças que atuam para fragilizá-lo pela diminuição da segurança, pela redução de perspectivas de crescimento e pela transitoriedade de vínculos empregatícios.

Esse pressuposto reflete de forma preponderante o impacto desses fenômenos, não somente na organização como um todo, mas, definitivamente, em relação a todos os seus participantes individualmente (BASTOS; BORGES-ANDRADE, 2002). 
É importante destacar que inúmeros estudos têm demonstrado que o êxito das mudanças pretendidas depende, em grande parte, da forma como as organizações lidam com o envolvimento do trabalhador mediante estratégias que assegurem o compartilhamento de valores, de objetivos e de políticas que garantam trocas equânimes entre as partes (BASTOS; BORGES-ANDRADE, 2002).

Os estudos científicos iniciais sobre o comportamento de funcionários apontavam sobretudo, os aspectos do ambiente físico de trabalho e a capacidade física do homem como os responsáveis pela execução de um trabalho de qualidade. Atualmente têm-se valorizado mais aspectos subjetivos. Por isso, a motivação se transformou no eixo básico de investigação do comportamento do trabalhador (BORGES-ANDRADE; PILATI, 1999). Dentre as teorias motivacionais, surgiram pesquisas sobre assuntos específicos como a satisfação e o comprometimento no trabalho. A satisfação com o trabalho medida pelo grau em que um empregado gosta do seu trabalho, ou quantos sentimentos positivos que um empregado tem por seu trabalho, é responsável por uma resposta de boa disposição para o trabalho e grande comprometimento com a organização, com o trabalho e com a sua própria carreira (GOULET; SINGH, 2002).

Segundo Rego (2003, p.25):

O tópico comprometimento vem ocupando há vários anos um lugar central nas preocupações dos investigadores que se debruçam sobre as atitudes e os comportamentos dos membros organizacionais. O autor acrescenta o que Swailes (2000, p. 199) expressou de modo a lapidar esse propósito ao enunciar que 'será difícil encontrar na literatura sobre organizações um tópico que tenha atraído mais interesse do que o comprometimento'.

Grapeggia (2002), ao estudar a relação do comprometimento e a qualidade de ensino, segundo a percepção de professores e alunos universitários, considera que a pesquisa sobre comprometimento do trabalhador com a organização e com o seu trabalho insere-se entre os estudos que buscam identificar e compreender fatores pessoais que determinam o comportamento humano no trabalho, integrando uma subárea denominada de atitudes no trabalho. E, considerando o aumento das expectativas da sociedade referentes à qualidade educacional, existe uma consciência de que as melhorias contínuas são importantes para se assegurar o desempenho econômico e o crescimento organizacional, através das melhorias em seu ambiente interno.

Lauer- Leite (2006) reforça a importância dos estudos sobre o comprometimento, relatando que as pesquisas sobre comprometimento organizacional têm incluído trabalhadores de diferentes profissões e setores da economia, numa tentativa de buscar entender a natureza do vínculo entre o trabalhador e a organização e de forma a contribuir para o desenvolvimento de estratégias que propiciem maior uniformidade entre os objetivos organizacionais e os dos trabalhadores. A análise dos aspectos do comportamento organizacional também é importante, uma vez que é produto da cultura, de 
valores e de políticas organizacionais, que redundam no tipo de vínculo que o trabalhador tem com a organização que, em última análise, influem sobre a produtividade e qualidade dos serviços das organizações.

Segundo Goulet e Singh (2002), os diversos estudos realizados demonstram que as variáveis preditoras de comprometimento organizacional envolvem o crescimento ocupacional proporcionado por políticas institucionais, à existência de políticas justas de gestão de recursos humanos e a imagem da organização na sociedade.

Tam, Korczynski e Frenkel (2002) corroboram essa idéia detalhando que as relações empregatícias têm efeitos significantes no comprometimento, o que fica evidenciado, nos últimos anos, diante das mudanças nos sistemas de contratação, orientadas pelo modelo de mercado, com uma força de trabalho reduzida e uma maior informalidade nos contratos de trabalho, através do aumento nos contratos temporários, nos contratos de meio período e nas sub-contratações. Esse novo relacionamento se torna superficial, na medida em que tanto as organizações quanto os funcionários têm consciência de que será uma relação de curta duração e porque retira da organização a preocupação com os interesses dos empregados, gerando um baixíssimo comprometimento com a organização, com o trabalho e nas atitudes dos empregados dentro das empresas.

Segundo o Ministério da Saúde (2007), o cenário brasileiro com relação ao profissional de nutrição, e conseqüentemente aos seus serviços, vem se modificando de forma muito rápida na última década. Primeiro, pelo aumento significativo no número de profissionais formados, que passaram de 7.249 em 1996 para 34.410 em 2004. Segundo pelo aumento na diversificação no campo de atuação, que além das áreas clássicas: clínica, institucional e saúde coletiva, agora incorpora a nutrição esportiva, o marketing, as indústrias de alimentos e a docência. E em terceiro, a nova formação profissional, através da instituição das Diretrizes Curriculares Nacionais do Curso de Graduação em Nutrição que passou a definir o nutricionista como:

\footnotetext{
O profissional com formação generalista, humanista e crítica, capacitado a atuar, visando à segurança alimentar e à atenção dietética, em todas as áreas do conhecimento em que a alimentação e nutrição se apresentam fundamentais para a promoção, manutenção e recuperação da saúde e para a prevenção de doenças de indivíduos ou grupos populacionais, contribuindo para a melhoria da qualidade de vida, pautado em princípios éticos, com reflexão sobre a realidade econômica, política, social e cultural (MINISTÉRIO DA SAÚDE, 2007).
}

Essa nova visão do nutricionista propiciou o aumento no campo de atuação profissional, bem como uma maior necessidade na ampliação das suas habilidades e competências. No entanto, o mercado de oferta de trabalho, em muitas regiões, não atende a esse crescimento acelerado, o que gera a necessidade de articulação intersetorial, para que o setor saúde, tanto público quanto privado, possa 
dispor de corpo técnico em quantidade e em qualidade. Nesse sentido, é necessária a qualificação do processo de formação em saúde e a universidade é agente fundamental para essa execução (MINISTÉRIO DA SAÚDE, 2007).

O Hospital Universitário de Brasília conta com cerca de 300 funcionários em seu serviço de nutrição, distribuídos em diversos níveis como funcionários administrativos, serviços gerais, cozinheiros, magarefes, almoxarifes, coladeiras, copeiros, técnicos em nutrição e nutricionistas. É um serviço ininterrupto que funciona em três turnos de trabalho: matutino, vespertino e noturno. Através de suas práticas diárias, observa-se que, por muitos anos, as deficiências diversas como estrutura, material, disponibilidade de gêneros alimentícios, remuneração inadequada, deficiência de mão-de-obra, grande número de contratações temporárias entre outros, ocasionou uma queda na qualidade do serviço prestado, com diminuição dos esforços com o trabalho e da satisfação, bem como um elevado nível de absenteísmo e afastamento por doenças, interferindo sobremaneira no comprometimento dos funcionários contratados (UNB, sd).

O HUB conta atualmente com 289 leitos, 121 salas de Ambulatório e 33 especialidades médicas, servindo à comunidade do Distrito Federal nos níveis primário, secundário e terciário, recebendo ainda pacientes das cidades do entorno de Brasília e oriundos de várias outras Unidades da Federação, sendo portanto, um hospital de referência onde é desenvolvido um importante trabalho de ensino, pesquisa e assistência (UNB, sd).

Portanto, o HUB - Hospital Universitário de Brasília é um local de ensino das atividades práticas profissionais, que acaba por acumular dois propósitos: um primeiro ligado ao meio acadêmico, mais precisamente de formação dos profissionais em saúde - atuando como um hospital-escola, e um segundo como prestador de serviços públicos de saúde para a comunidade onde está inserido. De acordo com Rebello (2005), a preocupação com a qualidade é um fator importante entre as pessoas, especialmente na relação de troca que atenda às suas necessidades. Com o aumento da competitividade, a população passa a exigir mais qualidade no atendimento às suas necessidades, por isso, torna-se necessária a adaptação das organizações a essa nova realidade mundial, procurando garantir efetivamente a excelência na prestação de seus serviços. $\mathrm{O}$ mau desempenho organizacional, como o descontentamento profissional, a alta taxa de rotatividade, a desqualificação profissional, irá refletir nos serviços oferecidos ao cliente, no caso do HUB, seus alunos e pacientes (UNB, sd).

Segundo Grapeggia (2002), para definir sua qualidade e produtividade, é fundamental o investimento na gestão de pessoas, uma vez que é pelas pessoas que passa o sucesso ou fracasso de qualquer plano de administração. Por tanto, com o grande crescimento no número de faculdades particulares, a globalização e a evolução tecnológica, onde também a educação caminha para o virtual, 
a busca por competitividade, qualidade na prestação de serviços e reconhecimento público de excelência se torna ainda maior e mais necessário, por isso, há a necessidade de que o HUB como local de prática educacional permaneça, em conjunto com toda a UNB, como um local de excelência na prestação de serviços e formação de profissionais.

\section{1- Problema da pesquisa}

Acreditando que o estudo do comprometimento de funcionários pode contribuir para o desenvolvimento da organização para a qual eles prestam serviço, o presente trabalho buscou analisar o grau de comprometimento organizacional, de comprometimento com o trabalho e de comprometimento com a carreira dos funcionários do serviço de nutrição do Hospital Universitário de Brasília.

E ainda, baseando-se na idéia de que os interesses entre os indivíduos em seu ambiente de trabalho se manifestam através da manutenção de comportamentos capazes de contribuir na realização do trabalho, avaliou-se a relação entre esses três diferentes focos do comprometimento com o desempenho desses funcionários. A pesquisa baseou-se em questionário que mensura o nível, tanto dos comprometimentos quanto do desempenho.

\section{2- Objetivos}

\subsection{1- Objetivo Geral}

Este estudo tem como objetivo geral verificar o comprometimento de funcionários do serviço de nutrição do Hospital Universitário de Brasília.

\subsection{2- Objetivos Específicos}

Como objetivos específicos, pretende-se nesta monografia:

i. Realizar revisão de literatura sobre: comprometimento com o trabalho, com a organização e com a carreira;

ii. Identificar o grau de comprometimento com o trabalho, com a organização e com a carreira dos funcionários de diferentes funções do serviço de nutrição do Hospital Universitário de Brasília; 
iii. Levantar o nível de desempenho dos funcionários de diferentes funções do serviço de nutrição do Hospital Universitário de Brasília.

\section{2- REFERENCIAL TEÓRICO}

\section{1- Histórico do Comprometimento}

A partir da década de 40 emerge a idéia do homem econômico e da organização como um sistema sócio-técnico, para qual o indivíduo é como uma peça do "quebra-cabeça" industrial, sem autonomia e tampouco iniciativa no âmbito da produção (PEREIRA; OLIVEIRA, 2000). Esse é o paradigma taylorista-fordista, representativo do modelo de burocracia mecânica, que em suma concebe que o homem é um ser com uma propensão natural para a inércia e que deve ser pressionado a trabalhar.

Em contrapartida, de acordo com a abordagem humanística, explicitada por Elton Mayo, a idéia do homem econômico perde intensidade e em seu lugar surge a preocupação de ajustar o indivíduo ao trabalho. Enquanto Taylor sugere que a organização eficiente por si só leva a uma melhor produção, Mayo a considera incapaz, se as necessidades psicológicas dos trabalhadores não forem identificadas e satisfeitas. Apesar de dar ênfase à satisfação no trabalho, a questão do comprometimento ainda não é mencionada. Trata-se de uma conduta mais estável, chegando a ser, teoricamente, um preditor positivo para a mensuração do desempenho do indivíduo na organização (PEREIRA; OLIVEIRA, 2000).

Conforme relata Bastos, Correa e Lira (1998), os achados dos anos sessenta e setenta direcionavam para a idéia de que os vínculos de lealdade e comprometimento com a organização e com a carreira são antagônicos, chamada de incongruência do vínculo, principalmente nas organizações burocráticas, ou seja, quanto maior o comprometimento com a profissão / carreira menor o comprometimento com a organização e vice e versa.

As publicações na área do comprometimento organizacional começam a aumentar significativamente em número nas décadas de 1970 e 1980, acompanhando as mudanças que as organizações estão enfrentando, sobretudo na compreensão da relação indivíduo-organização e todas as atitudes que a permeiam. Sobretudo em decorrência das expectativas sobre os efeitos que a intensidade do comprometimento pode gerar nos próprios indivíduos, nas organizações e, por extensão, na sociedade como um todo (BORGES-ANDRADE; PILATI, 1999). 
Para Mota e Fossá (2005) as transformações ocorridas nas relações de trabalho a partir da década de setenta nos países desenvolvidos e na década de oitenta no Brasil, principalmente a visão competitiva de mercado, além de alterar o nível de exigência, tornaram-se uma ameaça de ruptura do vínculo do funcionário com a organização. Por tanto passaram a ser de extrema importância os estudos acerca do comprometimento organizacional, na tentativa de obter respostas e poder influir no comportamento e no envolvimento das pessoas dentro das organizações.

Segundo Borges-Andrade e Pilati (1999), é extensa a literatura sobre os antecedentes de comprometimento. Os diversos estudos realizados no Brasil demonstram que as variáveis preditivas de comprometimento organizacional envolvem o crescimento ocupacional proporcionado por políticas institucionais, a existência de políticas justas de gestão de recursos humanos e a imagem da organização na sociedade. Dentre as características pessoais, maiores idades associam-se a níveis mais elevados de comprometimento, assim como a adoção de valores que integram a 'ética protestante do trabalho'. A correlação positiva mais elevada encontra-se com a percepção do indivíduo quanto à sua competência pessoal. O comprometimento tende a decrescer com o aumento do nível educacional.

Os autores ainda observam que, quanto às características do trabalho, há correlações positivas significativas entre comprometimento e variedade, caráter não rotineiro e escopo do trabalho. Para eles os aspectos das relações grupo-liderança mostram-se positivamente associadas ao comprometimento: interdependência das tarefas, comportamentos de estruturação, comunicação e consideração do líder e estilo participativo. No entanto, registram correlações negativas moderadas entre comprometimento e ambigüidade, conflito e sobrecarga do papel, enquanto que para as correlações entre comprometimento e características organizacionais tais como tamanho e centralização identificaram como praticamente nulos, nos estudos publicados no exterior (BORGES-ANDRADE; PILATI, 1999).

Segundo levantamento bibliográfico feito por Tam, Korczynski e Frenkel (2002), nos estudos mais antigos, apesar de o comprometimento organizacional reduzir as taxas de rotatividade e absenteísmo, ele definitivamente apresentava resultados positivos nos esforços pessoais e na satisfação com o trabalho. Mas, na maioria dos estudos atuais, ficou evidenciado que os conhecimentos e as capacidades no trabalho, as inter-relações pessoais, o sistema de recompensas e o controle nas relações são elementos cruciais no perfil do trabalho dentro das organizações e promovem o comprometimento dos funcionários, os seus esforços no trabalho e a sua satisfação no trabalho.

Para Meyer e col. (1989) o grande interesse que se tem hoje sobre o comprometimento organizacional se baseia na comprovação de ele estar negativamente relacionado com a rotatividade, ou seja, funcionários comprometidos estão menos propensos a deixarem a organização que funcionários sem comprometimento. Como a rotatividade significa um custo alto para as organizações, o 
comprometimento passa então, a ser uma característica desejada entre os funcionários. Por isso, o comprometimento se tornou um item importante nas preocupações gerenciais, já que o capital humano e intelectual tem se tornado cada vez mais importante para o funcionamento das organizações.

\section{2- Comprometimento organizacional}

Muitas são as concepções do que seria o dito comprometimento organizacional. Para Meyer e Allen (2000 apud REGO; SOUTO, 2004, p.1) o comprometimento organizacional pode ser concebido com um estado psicológico que caracteriza a ligação dos indivíduos à organização.

O comprometimento organizacional é, então, parte de um 'contrato psicológico' entre empregados e organização. É uma relação não-formal onde ficam implícitos os direitos e obrigações de cada lado baseados nas expectativas e promessas (LAUER-LEITE, 2006).

Mowday, Porter e Steers (1982 apud BORGES-ANDRADE; PILATI, 1999, p.1) definem comprometimento organizacional como "a força relativa da identificação e envolvimento de um indivíduo com uma organização particular" que se expressa em três dimensões: (a) uma forte crença e aceitação dos valores e objetivos da organização; (b) um desejo de exercer considerável esforço em favor da organização e (c) um forte desejo de se manter como membro da organização. Para os autores, essa concepção enfoca a natureza afetiva da relação de identidade do indivíduo com as metas da organização. Dentro desta linha conceitual, o comprometimento organizacional representa algo além da simples lealdade passiva a uma organização. Ele envolve uma relação ativa, na qual o indivíduo deseja dar algo de si próprio para contribuir com o bem-estar da organização.

Segundo Allen e Meyer (1996), a ligação psicológica entre empregados e sua organização pode tomar três formas distintas, cada uma delas com uma nomenclatura bem definida. O comprometimento afetivo refere-se à identificação, ao envolvimento e à ligação emocional com a organização. Assim, os empregados com elevado comprometimento afetivo permanecem na empresa porque eles assim o querem. O comprometimento instrumental refere-se ao comprometimento baseado na percepção pelos empregados dos custos associados ao sair da organização. Então, os empregados com forte comprometimento instrumental permanecem na organização porque assim o precisam. Finalmente, comprometimento normativo refere-ser ao comprometimento baseado em sentimentos de obrigação com a organização. Os empregados com elevado comprometimento normativo permanecem na organização porque assim o devem.

Esse e outros autores denominam de enfoque instrumental quando o comprometimento organizacional é visto como resultado das recompensas e custos associados à condição de integrante da organização. Essa divisão no conceito de comprometimento organizacional visa superar a insuficiência 
das explicações correntes para esse tipo comportamento ou para o fato de que indivíduos se envolvem em formas de atividades que se tornam consistentes e que persistem ao longo de algum período de tempo.

Segundo Pereira e Oliveira (2000), o conceito de comprometimento organizacional exprime mais que uma orientação básica para os seus papéis de empregados. Na verdade, eles trazem para as organizações um conjunto de códigos normativos que especificam maneiras moralmente corretas de dominação. O que significa dizer que o apego do trabalhador se fixa na percepção da legitimidade regimental do empregador, através das relações de autoridade que governam o controle do empregador e a subordinação dos trabalhadores.

Os mesmos autores definem o apego como o interesse do indivíduo em se estabilizar em seu emprego atual ou a expectativa de utilidade atribuída, pelo trabalhador, a dois cursos de ação: permanecer versus buscar novo emprego. Dessa forma, o termo comprometimento é visto de uma forma mais simples, uma vez em que se traduz o comprometimento ou apego como o simples ato de permanecer versus sair, o que pode ser revelado por comportamentos ou comunicações (verbais ou não verbais) do trabalhador (PEREIRA; OLIVEIRA, 2000).

Ainda segundo Pereira e Oliveira (2000), o enfoque normativo centrado na estrutura das atitudes e no seu poder preditivo em relação ao comportamento se apóia nos conceitos de sistemas culturais e motivacionais na determinação do comportamento humano nas organizações, sendo a cultura definida como o conjunto de valores partilhados que produzem pressões normativas sobre os membros. Tais pressões associam-se ao sistema de recompensas (motivação instrumental) para influenciar o comportamento. Para os autores a cultura organizacional é vista como o fator principal que pode estar diretamente ligado ao comprometimento organizacional, propiciando maior ligação dos membros à organização. Assim, indivíduos comprometidos apresentam certos comportamentos, não porque eles calculam que, ao apresentá-los, obterão benefícios pessoais, mas porque eles acreditam que é certo e moral fazê-los. Segundo os autores, o enfoque comportamental, caracteriza o comprometimento organizacional como uma avaliação que o trabalhador realiza para manter a harmonia entre o seu comportamento e as suas atitudes.

Para Kiesler e Sakamura (1966) apud Pereira e Oliveira (2000, p.5) o comprometimento organizacional é um vínculo do indivíduo com atos ou comportamentos, fazendo com que as cognições relativas a tais atos se tornem mais resistentes às mudanças posteriores. Bastos (1993) sugere que o comprometimento organizacional pode ser equiparado com sentimentos de auto-responsabilidade por um determinado ato, especialmente se eles são percebidos como livremente escolhidos, públicos e irrevogáveis. Assim, os indivíduos tornam-se comprometidos pelos resultados de seus próprios atos, ou 
seja, existe uma pressão psicológica que força os mesmos a se comportarem de forma coerente com os resultados de seu comportamento prévio. Portanto, dentro deste enfoque, a avaliação do compromisso não pode se restringir a comunicações verbais dos trabalhadores.

Pereira e Oliveira (2000) completam que o comprometimento organizacional caracteriza-se então como um construto observável em comportamentos realizados que superam as expectativas exigidas pela organização. Os indicadores utilizados para tal avaliação podem se resumir em: assiduidade, tempo no emprego e qualidade no desempenho das tarefas.

Contribuindo para essa idéia, os estudos de Mota e Fossá (2005) ressaltam que a qualidade na comunicação interna altera a intensidade do vínculo do funcionário para com a organização. Quanto mais fluidas as comunicações, quanto mais eventos de integração, quanto maiores os benefícios e as políticas sociais dentro da organização, maior o vínculo do funcionário, ou seja, maior o seu comprometimento. Dessa forma, o funcionário passa a se apropriar dos valores organizacionais, a 'vestir a camisa' da empresa e se torna inserido e pertencente a ela, percebem a equidade funcional como um elemento importante de perpetuação do trabalho.

Apesar dessa amostra de diversos enfoques e definições parece haver um eixo central que norteia a todos. É o que aponta Mowday e col. (1982 apud BORGES-ANDRADE; PILATI, 1999), quando afirmam que todas as definições e instrumentos de mensuração do comprometimento organizacional convergem para um ponto comum, ou seja, consideram-no como um vínculo do indivíduo para com a organização, diferindo apenas nas formas de desenvolvimento.

2.2.1- Abordagem uni e multidimensional do Comprometimento Organizacional:

Baseando-se na pesquisa de Rego (2003), genericamente, presume-se que as pessoas mais comprometidas têm maiores probabilidades de permanecerem na organização e de se empenharem na realização de seu trabalho e no alcance dos objetivos organizacionais. O construto é multidimensional, sendo a tese mais comum a que sugere a tripartição: comprometimento afetivo, normativo e instrumental.

Quadro 1: Os três componentes mais comuns do comprometimento organizacional 


\begin{tabular}{|c|c|c|c|}
\hline CATEGORIAS & CARACTERIZAÇĀO & $\begin{array}{c}\text { A PESSOA PERMANECE } \\
\text { NA ORGANIZAÇĀOO PORQUE ... }\end{array}$ & $\begin{array}{c}\text { ESTADO } \\
\text { PSICOLÓGICO }\end{array}$ \\
\hline Afetiva & $\begin{array}{l}\text { Grau em que o colaborador se sente emocionalmen- } \\
\text { te Ilgado, Identificado e envolvido na organızaçäo. }\end{array}$ & ... sente que quer permanecer. & Desejo \\
\hline Normativa & $\begin{array}{l}\text { Grau em que o colaborador possul um sentido da } \\
\text { obrigaçăo (ou do dever moral) de permanecer na } \\
\text { organzaçăo. }\end{array}$ & ... sente que deve permanecer. & Obrigação \\
\hline $\begin{array}{l}\text { Instrumental } \\
\text { (ou calculativa) }\end{array}$ & $\begin{array}{l}\text { Grau em que } 0 \text { colaborador se mantém IIgado à or- } \\
\text { gantzaçäo devido ao reconhecımento dos custos as- } \\
\text { soclados com sua saída da mesma. Este reconhecl- } \\
\text { mento pode advir da ausêncla de alternatıvas de } \\
\text { emprego, ou do sentımento de que os sacrificios pes- } \\
\text { soals gerados pela saída serăo elevados. }\end{array}$ & $\begin{array}{l}\text {... sente que tem necessidade } \\
\text { de permanecer. }\end{array}$ & Necessidade \\
\hline
\end{tabular}

Extraído de REGO, 2003 (p.27).

\begin{abstract}
Empregados com um forte comprometimento afetivo permanecem na organização porque eles querem, aqueles com comprometimento instrumental permanecem porque eles precisam e aqueles com comprometimento normativo permanecem porque eles sentem que são obrigados (ALLEN; MEYER, 1990 apud MOTA; FOSSÁ, 2005, p.4).
\end{abstract}

De acordo com Meyer e col. (1989) apesar de tanto o comprometimento afetivo como o comprometimento instrumental refletirem os vínculos que os empregados mantêm com a organização diminuindo o desejo de rotatividade, a natureza desse vínculo é bastante diferente. O que significa dizer que funcionários com vínculo afetivo permanecem na organização por que eles desejam, enquanto que os com vínculo instrumental permanecem porque eles precisam. Segundo os autores, essa diferenciação no vínculo do comprometimento gera também um desempenho diferenciado.

Para esses autores, os funcionários que estão afetivamente comprometidos tendem a atuar de forma melhor, mais profissional, com maior conhecimento e a estarem mais satisfeitos, enquanto que funcionários com vínculo instrumental, que percebem que seria custoso para eles deixar a organização, tendem a contribuir menos, a desprender menos esforço com o trabalho do que aqueles que se sentem livres em deixar a organização. Para a organização o comprometimento afetivo reflete uma identificação com a empresa beneficiando-a com baixa rotatividade e um desempenho superior. Já o comprometimento instrumental apesar de manter o benefício da permanência do funcionário, o faz à custa de um pobre desempenho (MEYER et al.,1989).

De acordo com Rego (2003) alguns investigadores aventam a possibilidade /pertinência de o comprometimento instrumental ser dividido em duas vertentes: a) o indivíduo mantém-se ligado à organização porque sente que não tem alternativas de emprego; b) essa ligação assenta na idéia de que os sacrifícios pessoais inerentes à saída são elevados.

\title{
2.3- Comprometimento com o trabalho
}


No discurso de gestão de organizações, não há estudo mais comum que o entendimento da relação entre o comprometimento dos indivíduos e a competitividade das organizações. Segundo Rego (2003):

\begin{abstract}
A lógica subjacente é simples: inseridas em ambientes turbulentos - por exemplo, nas tecnologias, nos mercados, nos gostos e necessidades dos consumidores, nas estruturas setoriais -, as organizações necessitam de pessoas dispostas a 'irem mais além' do que aquilo que está formalmente prescrito, a adotarem comportamentos espontâneos em resposta a problemas inesperados, a fornecerem sugestões criativas e inovadoras para a resolução de problemas inéditos, a se identificarem com a organização - denotando 'amor à camisa' - e a atuarem como 'bons cidadãos organizacionais' (REGO, 2003, p. 26).
\end{abstract}

A exuberância das pesquisas pode ser creditada, em grau muito considerável, à evidência de que o comprometimento pode ter implicações na assiduidade, na rotatividade, na pontualidade, nos comportamentos de cidadania, na aceitação das mudanças e no desempenho dos membros organizacionais. Goleman (1998) apud Pereira e Oliveira (2000, p.6) reproduziu sucinta e globalmente a concepção subjacente ao discurso dominante quando traçou a seguinte linha argumentativa: quando comprometidas e devotas a seu trabalho, as pessoas estão dispostas a fazer sacrifícios, a suportar condições de trabalho altamente exigentes, isto é, a atuarem como patriotas de suas organizações e as pessoas empenhadas representam modelos de atuação que os restantes membros podem imitar.

De todas as formas de comprometimento, a com o trabalho é o foco mais próximo, mais tangível e o mais concreto (COHEN, 2000). E o envolvimento com o trabalho pode estar baseado na idéia de que o trabalho é central à existência de uma pessoa, através de um envolvimento bastante pessoal e na importância da auto-imagem que esse trabalho propicia. Nesse caso, o indivíduo está ligado ao trabalho, ao contrário do comprometimento organizacional em que a pessoa se encontra ligada à organização (GOULET; SINGH, 2002).

Para Cohen (2000) pessoas altamente comprometidas com o seu trabalho e a sua ocupação selecionam criteriosamente uma organização como um local apropriado de trabalho, dessa forma, poderão ficar altamente comprometidas com a organização. São as pessoas que buscam a organização que melhor se encaixa em suas necessidades e expectativas. Pessoas menos comprometidas podem ter assumido posições de trabalho por conveniência, sem escolha prévia, talvez, por pura necessidade financeira.

Em 1995, Bastos escreve que na linguagem cotidiana, o comprometimento é entendido como o grau de atenção, esforço, cuidado que a pessoa coloca ao realizar algo. Já na esfera científica o comprometimento passou a ser visto como uma adesão, um forte envolvimento do indivíduo com variados aspectos do ambiente de trabalho. 
No estudo de Goulet e Singh (2002) as varáveis de fora do trabalho como as demandas da família e do local de trabalho, não influíram negativamente no comprometimento com o trabalho como se imaginava, na verdade, aumentaram a dependência do empregado ao emprego, na medida em que aumentou o compromisso financeiro, o que pode ter sido responsável por levar a um maior comprometimento com a carreira.

\section{4- Comprometimento com a carreira}

Segundo Goulet e Singh (2002) o comprometimento com a carreira pode ser conceituado através do quanto uma pessoa se identifica com uma profissão e o quanto ela a valoriza e pela quantidade de tempo e esforço que gasta adquirindo conhecimento. Dessa maneira, uma pessoa pode se dedicar a um trabalho à custa de sua carreira ou sem se importar com ela. Estar envolvido com o trabalho e realizá-lo bem podem ser vistos como centrais para um progresso na carreira. Para Cohen (2000), uma pessoa extremamente envolvida com um trabalho irá também direcionar esse grande envolvimento para a ocupação, desenvolvendo grande comprometimento ocupacional.

Portanto, existem domínios cujas características estão inseridas e identificadas: - identidade com a carreira: o quão central é a carreira para a sua identidade; - percepção da carreira: o quão realista é a percepção sobre si e sobre a organização, transformando essa percepção em objetivos para a carreira; e - persistência com a carreira: o quão resistente à interrupção da carreira uma pessoa é, em ambientes ruins ou inadequados (GOULET; SINGH, 2002).

Para profissionais, o comprometimento com a ocupação (carreira) tem um grande efeito nos resultados do trabalho, possivelmente ainda maior e mais forte do que o comprometimento organizacional e do que o comprometimento com o trabalho, pois os profissionais podem se direcionar mais para as suas ocupações do que para as suas expectativas com a organização. Isso leva à conclusão de que o comprometimento com a ocupação deve ser incluído em qualquer conceituação da relação entre as formas de comprometimento e as variáveis nos resultados (COHEN, 2000).

De acordo com os achados de Goulet e Singh (2002), apesar de se esperar que aqueles que apresentem grande comprometimento com a carreira tenham também grande comprometimento organizacional, nem sempre é o que acontece. Em alguns casos, pessoas comprometidas com a sua carreira podem passar pelas organizações, se isso for um facilitador para o avanço na sua carreira. Por outro lado, algumas pessoas podem permanecer leais a uma mesma organização mudando de carreira dentro dela. De fato, o que acontece atualmente é que os empregados se sentem menos comprometidos com o caminho tradicional de ascensão numa única empresa. Para os autores, essa nova atitude reflete a perda da confiança dos empregados diante da persistência na erosão dos contratos psicológicos que 
promovem a lealdade. $\mathrm{O}$ medo crescente da perda do emprego transforma os empregados em indivíduos menos comprometidos com suas carreiras dentro da organização. O foco do empregado deixa de ser a organização e passa a ser o seu próprio desenvolvimento, a sua carreira e a sua ascensão.

Confirmando essa idéia, Bastos, Correa e Lira (1998) relatam que as mudanças nos padrões das relações de trabalho com uma redução na contratação e terceirização dos trabalhadores ampliam as incertezas e levam ao não atendimento das demandas dos funcionários de segurança e estabilidade no trabalho, levando ao enfraquecimento do vínculo com a organização e fortalecendo o vínculo com a carreira.

Outra questão é que empregados bem direcionados em suas necessidades e em seus objetivos tendem a ter planos e estarem orientados a uma relação de trabalho de longa data e em conseqüência, estar comprometidos com suas carreiras (GOULET; SINGH, 2002). Segundo os mesmos autores, os empregados cujos trabalhos se encaixam nas expectativas gerais sobre a carreira tendem a estar mais satisfeitos com o seu ambiente de trabalho e devem ter bastante comprometimento com a carreira. Isso também significa dizer que, apenas aquelas carreiras / profissões que necessitam de maior grau de escolaridade e conseqüentemente levam a um maior status, geram maior comprometimento com a carreira.

Para Bastos, Correa e Lira (1998, p.14) “o comprometimento com a organização e a profissão podem existir harmonicamente na forma de um duplo vínculo”. Em seu estudo, os autores encontraram que a maioria dos trabalhadores pesquisada tendeu a apresentar comprometimento com a organização e com a carreira ao mesmo tempo. Nesse caso, o que leva a presença dos dois vínculos associados harmonicamente é a possibilidade que os indivíduos encontram de exercer a sua profissão, em consonância com a sua vocação, e com isso obterem realização profissional.

\section{5- Outros focos do comprometimento}

Para Bastos, Correa e Lira (1998, p.1) "múltiplos aspectos podem ser alvos do comprometimento do indivíduo", além dos acima mencionados, como com a organização, com o trabalho e com a carreira, também se pode incluir com o sindicato, com o grupo de trabalho, com uma tarefa individualmente, com a família, com a religião, com o partido político, etc. Como um indivíduo pode estar sob influencia de vários focos do comprometimento, eles podem gerar reações harmônicas ou conflitivas no comprometimento. 
Cooper-Hakim e Viswesvaran (2005) em sua pesquisa revelaram que há realmente a influencia de vários focos no comprometimento e que os mesmos se correlacionam, gerando variações específicas nas diferentes formas de comprometimento. Segundo os autores, esses achados sugerem que pesquisadores podem melhorar sua compreensão a cerca dos comportamentos no local de trabalho com essa visão múltipla do comprometimento.

Na seqüência serão revisados mais alguns focos do comprometimento, no entanto, os mesmos não farão parte da investigação do presente trabalho.

\subsection{1- Comprometimento com o social/grupo}

Segundo Cohen (2000), há uma distinção conceitual entre o comprometimento com o grupo e o comprometimento organizacional. O comprometimento com o grupo se relaciona com variáveis de níveis de relacionamento em grupo como coesão, identidade, enquanto o comprometimento organizacional se relaciona mais com varáveis como conflitos com o papel na organização e expectativas encontradas. A racionalidade desses relacionamentos está na importância do grupo de trabalho em formar uma orientação do empregado para com o trabalho. Em sua revisão, o autor salienta que os pesquisadores relacionaram o envolvimento com o trabalho com o número de pessoas contatadas por dia no trabalho e a necessidade do trabalho próximo com outras pessoas, e encontraram que pessoas envolvidas socialmente podem ser relutantes em quebrar as ligações sociais e por isso, podem escolher em permanecer na organização.

Nesse mesmo trabalho, o autor esclarece que, uma pessoa pode desenvolver uma ligação maior e mais pessoal com um grupo do que com uma carreira ou com um trabalho porque um grupo é um alvo mais próximo em uma unidade imediata de trabalho de uma pessoa, enquanto a carreira, o trabalho e até mesmo a organização, são alvos mais distantes, por tanto, o envolvimento com o trabalho e o comprometimento com o grupo de trabalho estão intimamente relacionados.

Para Clugston, Howell e Dorfman (2000), tanto da perspectiva conceitual quanto da metodológica, os pesquisadores devem se preocupar em determinar a extensão com que as atitudes dos empregados são influenciadas pela socialização cultural em contraste às diferenças psicológicas individuais, independentes da cultura. Desta forma, as atitudes dos empregados poderão ser previstas com base na dimensão cultural, formada pelo grupo, dentro de um mesmo ambiente de trabalho. Para os autores, não apenas o atual sistema teórico pode ser usado através de uma grande diversidade de culturas, mas também pode ser efetivo por fazer importantes distinções entre culturas aparentemente homogêneas. 
Ao associar o comprometimento com o grupo com o desempenho no trabalho, os autores ressaltam a importância que as culturas coletivistas dão à lealdade ao coletivo, desvalorizando o que é individual, elevando a obrigação moral dos indivíduos para permanecerem na organização. No entanto, para eles não existem evidências empíricas que confirmem a noção de que as crenças coletivistas influenciam o comprometimento organizacional e também não há evidência que outras crenças coletivas possam prever as formas de comprometimento organizacional.

Uma questão conceitual adicional se refere à dificuldade de separar os efeitos da cultura pessoal dos indivíduos, através do processo de socialização e comunicação, dos efeitos das experiências de vida individuais. Apesar de as experiências individuais estarem misturadas no meio social, o desenvolvimento pessoal é necessariamente único (CLUGSTON; HOWELL; DORFMAN, 2000).

\subsection{2- Comprometimento ético}

De acordo com a revisão de literatura feita por Cohen (2000), a noção de ética no trabalho, segundo muitos autores, está relacionada a questões religiosas, principalmente à religião protestante, também chamada de ética protestante no trabalho. Por isso, pessoas com forte noção ética com o trabalho podem motivar-se a dedicar mais esforços, e continuam a fazê-lo mesmo quando estão entediadas ou cansadas, e a assumirem responsabilidades pelo seu trabalho. Eles têm uma obrigação moral em cumprir suas tarefas na melhor de suas habilidades. E ainda, eles têm mais prazer em estar envolvidos com o trabalho do que pessoas com baixa relação ética, não ligada à religião.

Para Cooper-Hakim e Viswesvaran (2005), o comprometimento ético no trabalho deve ser considerado um conceito mais abrangente do que somente ligado à ética protestante no trabalho. Talvez, isso se deva às mudanças de valores da força de trabalho mundial influenciada pelas mudanças geradas pela globalização.

\section{5- Comprometimento e desempenho no trabalho}

De acordo com Swailes (2004), a maioria das pesquisas no campo do comprometimento tem enfocado somente o comprometimento organizacional e não valoriza como os outros focos do comprometimento estão relativamente conectados com o desempenho no trabalho. O comprometimento organizacional, através de atitudes positivas para com a organização, se tornou o paradigma dominante na literatura tanto como um resultado desejado em práticas de recursos humanos, como a mais usada operacionalização em estudos quantitativos.

Para Pereira e Oliveira (2000) uma das premissas comuns ao estudo do comprometimento é que níveis elevados de comprometimento contribuem para níveis elevados de desempenho. De acordo com 
sua revisão de literatura, os autores explicam que o comprometimento em si não possui fatores motivacionais, não sendo fator suficiente para compelir à ação. Contudo, o comprometimento acaba por influenciar a maneira como os indivíduos reagem às situações, compelindo-os a agir, devido às suas propriedades de ligar e prender indivíduos a comportamentos. Assim sendo, as empresas adotam práticas com o objetivo de obter maior comprometimento de seus colaboradores, embora os resultados destas práticas também possam produzir efeitos negativos. No entanto, o gerenciamento de recursos humanos é uma das poucas formas de vantagem competitiva que não pode ser facilmente imitada.

De acordo com Cohen (2000), no relacionamento entre o envolvimento com o trabalho e os resultados do trabalho, um estado de identificação cognitiva com o trabalho, baseado na percepção de seu potencial de satisfação das necessidades psicológicas salientadas, espera-se que preceda e depois acione o processo motivacional que influencia a motivação, os esforços, e por último a atuação, as faltas e as trocas de emprego (rotatividade). Isso implica que alguns comportamentos no trabalho estão mais proximamente relacionados com o envolvimento no trabalho, enquanto outros estão mais distanciados como as faltas e as trocas de emprego.

Rego (2002) fez alusão ao paradoxo do mundo organizacional atual, afirmando que a reivindicação da 'entrega' dos indivíduos à organização coabita com certo 'descarte' da própria organização perante eles. Para o autor a idéia fica clara quando levantam a idéia de que se pode obter mais produtividade de trabalhadores satisfeitos como se pode extrair mais leite de vacas contentes.

Os resultados do trabalho podem ser mais bem compreendidos como um resultado da combinação de todos os tipos de comprometimento, mais do que como um resultado de qualquer um dos tipos separadamente (COHEN, 2000).

Nessa direção Meyer e col. (1989) em seu estudo encontraram correlações positivas e significantes entre o comprometimento afetivo e o desempenho. Em contraste, encontraram correlação negativa entre o comprometimento instrumental e o desempenho. Já, entre satisfação com o trabalho e desempenho, idade e desempenho, tempo de serviço e desempenho, não encontraram correlação significativa. De acordo com esses achados os autores afirmam que as relações entre comprometimento e desempenho variam como uma função da natureza do comprometimento: quanto mais afetivo for o comprometimento, melhor o desempenho, enquanto que quanto mais instrumental for o comprometimento, decai a qualidade do desempenho. Os autores ainda salientam que a inexistência de correlação significativa entre o desempenho e a satisfação com o trabalho reforça a idéia de que o comprometimento afetivo é orientado para com a organização e não para o trabalho ou para a carreira.

Morrow (1993 apud COHEN, 2000, p.388) refere que a questão que mais impede a compreensão do comprometimento com o trabalho é saber se cada foco do comprometimento é 
independente ou, se alguns são antecedentes ou conseqüência dos outros. Segundo Cohen (2000), essa questão tem grandes implicações pela natureza das inter-relações entre os focos do comprometimento, pois eles podem afetar a forma com que esses comprometimentos se relacionam com os resultados do trabalho.

Swailes (2002) critica essa visão argumentando que mesmo com forte evidencia empírica de que o aumento do comprometimento leva a um aumento do desempenho no trabalho, este tema ainda está longe de apresentar dados conclusivos, na medida em que essa evidencia se baseiam em resultados irregulares e que de fato, se apresentam com fraca correlação. E, existem também, resultados similares quando o desempenho é substituído por satisfação no trabalho.

Mowday, Steers e Porter (1979) reforçam esse argumento quando em seus resultados encontraram que há uma relação entre comprometimento e desempenho, mas que a força desse resultado se mostrou muito fraca. Também, com relação à rotatividade a relação com o comprometimento existe, só que fraca e que a rotatividade é influenciada por outras varáveis.

De acordo com Swailes (2002), a relação entre comprometimento e desempenho é maior ente os funcionários com menores salários. Para ele, a instabilidade financeira pode criar tanta insegurança que qualquer foco de um alto comprometimento anteriormente medido pode enfraquecer rapidamente após uma oferta de maior rendimento. $\mathrm{O}$ autor acredita que o desempenho é um conceito muito amplo, diferente do utilizado pelos pesquisadores que se baseiam em poucos dados do domínio do desempenho e que os seus achados contradizem a crença geral de que o comprometimento e o desempenho devem se correlacionar positivamente.

\section{3- METODOLOGIA}




\section{1- Tipo de pesquisa}

Este capítulo apresenta a metodologia utilizada nesta pesquisa. Em se tratando de um trabalho de conclusão de curso de pós-graduação em nível de especialização, buscou-se a reprodução de metodologia já validada e previamente utilizada, bem como instrumento também validado e utilizado na população brasileira.

Inicialmente, procedeu-se revisão de literatura acerca dos vários focos do comprometimento em banco de dados on-line de revistas especializadas como a Revista de Administração Eletrônica (RAE), Publicações ENANPAD, e em ferramentas de busca como a Científica e Scielo.

A revisão de literatura viabilizou o conhecimento sobre as várias formas do comprometimento nos tópicos abordados, situação atual, principais trabalhos já realizados e opiniões dos pesquisadores para que houvesse possibilidade de replicação de instrumento e comparação com os resultados. Assim, identificou-se a metodologia e instrumento a serem seguidos (SHEIBLE, 2004).

Os estudos de campos são desenvolvidos principalmente nas Ciências Sociais, onde se insere o comportamento organizacional. Este tipo de estudo, de um modo geral, "não tem como objetivo produzir ou reproduzir os fenômenos estudados" (ANDRADE, 1998 apud SCHEIBLE, 2004, p.36).

Trata-se de uma pesquisa descritiva, pois procura informar sobre a distribuição de um evento na população, em termos quantitativos (PEREIRA, 2001). Para Andrade (1998 apud SCHEIBLE, 2004, p.36), "uma das características da pesquisa descritiva é a técnica padronizada da coleta de dados, realizada principalmente através de questionários e da observação sistemática". De acordo com Pereira (2001), o pesquisador deve expressar a distribuição do evento estudado em freqüência de modo apropriado. A coleta de dados foi realizada de forma transversal.

\section{2- Local da Pesquisa}

A pesquisa foi realizada no HUB - Hospital Universitário de Brasília. No HUB, acumulam-se as atividades de ensino, pesquisa e extensão que o diferencia dos demais hospitais da cidade de Brasília: o compromisso com a formação de novos profissionais da área de saúde (médicos, enfermeiros, dentistas, nutricionistas, farmacêuticos, etc), indissoluvelmente ligado ao atendimento à população e à produção de conhecimento e desenvolvimento de novas tecnologias, adaptadas às características e exigências de nossa sociedade. Além da graduação, o HUB oferece estágios de pósgraduação e de nível médio em diferentes áreas e de diferentes escolas; em 2001 foram 58 estagiários de pós-graduação e 456 de nível médio; recebe alunos de Cursos de Pós-Graduação em Ciências da Saúde e em Ciências Médicas, em níveis de mestrado e doutorado, e alunos de vários cursos de 
especialização lato-sensu, de outras instituições, como os de Fisioterapia Pneumofuncional, Fisioterapia Reumatológica e Traumato-Ortopédica e Fisioterapia Neurofuncional (UNB, 2007).

O HUB conta atualmente com 289 leitos, 121 salas de Ambulatório e 33 especialidades médicas, servindo à comunidade do Distrito Federal nos níveis primário, secundário e terciário, recebendo ainda pacientes das cidades do entorno de Brasília e oriundos de várias outras Unidades da Federação, sendo portanto, um hospital de referência onde são desenvolvidos importantes trabalhos de ensino, pesquisa e assistência. A pesquisa sobre a satisfação dos pacientes do Sistema Único de Saúde (SUS), feita pelo Ministério da Saúde no ano de 2000 com cerca de 960 mil pacientes internados em hospitais do SUS, que analisaram a qualidade do atendimento, equipe de funcionários e instalações físicas do local onde ficaram deu ao HUB a maior nota de Brasília (UNB, 2007).

\section{3- Amostra}

Nesse contexto hospitalar está inserido o serviço de Nutrição que, atualmente conta com um quadro de funcionários composto de cerca de 300 funcionários, em níveis e funções diversas, onde constam funcionários admitidos por concurso público, servidores públicos, e por contrato temporário de trabalho, terceirizados. É importante esclarecer que submetidos ao serviço de nutrição, encontram-se duas divisões: a de Nutrição Clínica e a de Produção.

A amostra do estudo foi retirada da população de profissionais de nível superior e técnico, de ambas as divisões, representada pelos cargos de nutricionistas, técnicos em nutrição e demais funcionários do serviço de nutrição do HUB: cozinheiras, copeiras, almoxarifes, AOSD, etc.

Inicialmente, pretendeu-se utilizar toda a população de nutricionistas, que representariam 18 indivíduos, e de técnicos em nutrição, que representariam 15 indivíduos. No entanto, não foi possível, pois alguns funcionários apresentavam-se em férias ou em licença no período da coleta dos dados.

A amostra dos demais profissionais que não os nutricionistas e técnicos foi de $10 \%$ do total deles e determinada de forma aleatória simples, obtida ao acaso, de forma que cada elemento tivesse a mesma probabilidade de participar da pesquisa. Para tanto, foi realizado sorteio segundo número aleatório da folha de ponto. No caso de ter sido sorteado algum funcionário de férias ou em licença, procedeu-se a inclusão do nome consecutivo na folha de ponto.

Em resultado obteve-se uma amostra de 46 indivíduos respondentes da pesquisa, sendo 15 de nutricionistas, 11 técnicos em nutrição e 20 dos demais profissionais. Para maior fluidez da leitura, esses 20 demais profissionais serão doravante referidos apenas como funcionários.

\section{4- Instrumento}


Para Bastos (1995), os estudos sobre comportamento organizacional têm pecado por utilizar medidas que não permitem comparação entre estudos. Então, de acordo com Sheible (2004), uma das estratégias desta pesquisa foi utilizar medidas com propriedades validadas para medir o comprometimento, de preferência já traduzidas para o português, desde que disponíveis.

A diversidade conceitual que caracteriza a pesquisa do comprometimento resultou em consequiente variedade de instrumentos de mensuração. Ainda com base no estudo de Scheible (2004), para analisar o comprometimento organizacional optou-se por utilizar o Organizational Commitment Questionaire - OCQ, Escala de Comprometimento Afetivo, Instrumental e Normativo com a Organização de Meyer, Allen e Smith (1993) e os itens afetivos de Mowday (1982), todos instrumentos validados por Bastos (1994). Allen e Meyer (1996) em seu trabalho examinaram e validaram as três escalas de comprometimento através da revisão das pesquisas onde elas foram usadas. Essas medidas foram desenvolvidas com base no quadro teórico que integra as visões existentes sobre a atitude do comprometimento e que têm sido usadas em uma ampla variedade de amostras. Já para o comprometimento organizacional com foco no desempenho usou-se a escala de Meyer e Herscovitch (2001). Para eles o comprometimento caracteriza-se, de uma forma geral, como: uma crença forte e aceitação dos objetivos e valores da organização; a disponibilidade para despender esforço considerável em favor da organização ou um desejo constante de manter a associação com a organização (MOWDAY et al., 1982).

Os itens restantes referem-se ao comprometimento com a carreira, mensurados através de um instrumento, elaborado por Blau (1985), também validado por Bastos (1994). Os níveis de mensuração utilizados foram baseados na escala do tipo Likert variando de 1 (baixo comprometimento) a 5 (alto comprometimento), obedecendo à seguinte gradação para as respostas: 1 - discordo totalmente; 2 discordo parcialmente; 3 - nem concordo, nem discordo; 4 - concordo parcialmente e 5 - concordo totalmente. Para os itens com frase invertida ou na negativa a interpretação também deverá ser reversa.

O instrumento da presente pesquisa, o questionário utilizado, encontra-se no Apêndice A.

\section{5 - Procedimentos}

\subsection{1 - Coleta dos dados do instrumento}

O instrumento foi aplicado no período de 11 de maio a 01 de junho de 2007. Foram entregues os questionários em um horário acordado com a chefia imediata e preferencialmente, durante o expediente de trabalho. Para os participantes com nível de escolaridade média ou fundamental, em 3 casos, foi realizada entrevista individual utilizando o instrumento como roteiro, dessa forma, o 
preenchimento foi realizado pelas entrevistadoras, autoras desta pesquisa. Muitos questionários foram devolvidos através da chefia do setor de nutrição, e não diretamente às pesquisadoras, o que prejudicou a conferência da completude dos questionários, que em alguns casos acabaram por ficar incompletos, na medida em que não foi solicitada a identificação dos participantes.

\section{6 - Análises dos dados}

O material levantado através da resposta dos questionários preenchidos foi submetido à análise descritiva do conteúdo, pela qual buscou-se identificar o grau de comprometimento com a organização, com o trabalho e com a carreira e o grau de desempenho. Para a compilação e análise estatística dos dados foram utilizados os softwares estatísticos EXCEL 2000 e SPSS - Statistical Package for the Social Sciences (SPSS) versão 13.0. Para as correlações entre os grupos foi feito o Teste T e ANOVA.

Após a tabulação dos dados coletados foram realizadas as análises descritivas (distribuição das freqüências, médias e desvios padrão) das variáveis de comprometimento com a organização, trabalho e desempenho individual. 


\section{4- RESULTADOS E DISCUSSÃO}

Neste capítulo, serão apresentados os dados obtidos por meio desta pesquisa e que foram submetidos à análise estatística de acordo com as repostas fornecidas pelos respondentes.

A etapa da coleta de dados iniciou-se com a entrega de um total de 60 questionários. Dos nutricionistas e técnicos de nutrição obtivemos $88 \%$ e $73 \%$ de retorno de questionários preenchidos. Em relação aos funcionários, obtivemos um retorno de $64 \%$ de todos os questionários entregues. Apenas um questionário foi entregue sem qualquer dado demográfico e outro sem o cargo ocupado na instituição. Talvez em função do grande número de itens, alguns questionários foram entregues faltando uma ou mais respostas, por isso, nas análises nem sempre o $\mathrm{N}$ será referente ao total de 46. Em termos gerais, obtivemos 46 questionários dos 60 entregues o que representa cerca de $77 \%$ de retorno.

Na Tabela 1 estão demonstrados os dados demográficos e funcionais dos pesquisados.

A amostra foi composta na sua maioria por mulheres $(88,9 \%)$, jovens com idade média de 33 anos, variando de um mínimo de 22 a um máximo 67 anos, sendo que cerca da metade são casadas $(53,3 \%)$ e com nível superior de escolaridade. Quase a metade da amostra está até 3 anos na instituição $(44,4 \%)$, sendo a permanência média de 6,53 anos (desvio padrão 6,35), diferente da pesquisa de Pereira e Oliveira (2000) na qual os participantes tinham 11 ou mais anos de trabalho na instituição pesquisada. O cargo de maior freqüência na pesquisa foi o de nutricionista $(34,1 \%)$, seguido pelos técnicos de nutrição com um quarto da amostra. Em relação ao vínculo empregatício observamos a prevalência dos contratados, que são de fato a maioria dos funcionários do serviço de Nutrição.

A distribuição dos gêneros reflete ainda a tendência secular de considerar os aspectos relacionados à alimentação como uma área feminina como diz Costa (apud MINISTÉRIO DA SAÚDE, 2007, p.354). Nos cargos de nível superior e técnico essa tendência é confirmada, pois esses são cargos ocupados exclusivamente por mulheres. Apenas para os auxiliares administrativos, AOSD (auxiliares de serviços gerais) e cozinheiro foram encontrados participantes do gênero masculino. Segundo alguns autores, as mulheres tendem a ser mais comprometidas do que os homens (MATHIEU; ZAJAC, 1990 apud SCHEIBLE, 2004, p.56), o que não pôde ser observado neste estudo, pois a população do estudo foi quase completamente feminina. 
Tabela 1- Dados demográficos e funcionais da amostra.

\begin{tabular}{ll}
\hline \hline Gênero & \\
\hline Masculino & $11,1 \%$ \\
\hline Feminino & $88,9 \%$ \\
\hline Idade & 32,89 anos \\
\hline Média & 10,84 \\
\hline Desvio padrão & \\
\hline Estado civil & $35,6 \%$ \\
\hline Solteiro & $53,3 \%$ \\
\hline Casado & $6,7 \%$ \\
\hline Separado ou divorciado & $2,2 \%$ \\
\hline Viúvo(a) & $2,2 \%$ \\
\hline Outros & \\
\hline Grau de instrução & $6,7 \%$ \\
\hline $1^{\circ}$ grau incompleto & $8,9 \%$ \\
\hline $1^{\circ}$ grau completo & $11,1 \%$ \\
\hline $2^{\circ}$ grau incompleto & $24,4 \%$ \\
\hline $2^{\circ}$ grau completo & $48,9 \%$ \\
\hline Superior completo & \\
\hline Tempo de trabalho na instituição & 6,53 anos \\
\hline Média & 6,35 \\
\hline Desvio padrão & \\
\hline Cargo na instituição & $13,6 \%$ \\
\hline AOSD & $2,3 \%$ \\
\hline Cozinheiro & $2,3 \%$ \\
\hline Lactarista & $15,9 \%$ \\
\hline Copeira & $34,1 \%$ \\
\hline Nutricionista & $25 \%$ \\
\hline Técnico em nutrição & $6,8 \%$ \\
\hline Auxiliar administrativo & $51,1 \%$ \\
\hline Vínculo com a instituição & $48,9 \%$ \\
\hline Contratato ou terceirizado & \\
\hline Concursado & \\
\hline \hline
\end{tabular}

Fonte: dados da pesquisa

A participação na pesquisa de um maior número de nutricionistas e técnicas em nutrição já estava prevista na metodologia para a qual previu-se a coleta dos dados de todas as nutricionistas e de todas as técnicas de nutrição do hospital. Além disso, a perda de dados para os demais cargos foi importante e totalizou de $36 \%$ de questionários não preenchidos ou não entregues às pesquisadoras do total direcionado aos funcionários com cargos de nível primário e cujo vínculo empregatício é em grande maioria de contratados. Parte dessa perda pode ser explicada pela extensão do questionário, 69 itens mais os dados demográficos, que era sempre considerado como uma grande dificuldade pelos funcionários que recebiam a pesquisa. 
A referida extensão do questionário pode ser confirmada pelo tempo de preenchimento que nunca foi inferior a 10 minutos. O tempo mínimo de preenchimento foi observado para os pesquisados de nível superior, pois a coleta desses dados foi realizada durante uma reunião onde estava presente a grande maioria das nutricionistas. Para os funcionários que realizam sua função no ambiente da cozinha hospitalar, não houve a permanência das pesquisadoras no mesmo ambiente em que preenchiam o questionário. Isso porque o funcionamento dinâmico do serviço de nutrição não permite que os funcionários parem suas tarefas a qualquer momento em que são solicitados, como é o caso das cozinheiras, os auxiliares de cozinha, os AOSD, entre outros, o que determinou que seus questionários fossem entregues para serem preenchidos ao término da atividade ou antes mesmo de serem iniciadas as atividades no dia seguinte.

Inicialmente estão apresentados os dados de toda a amostra e a seguir serão efetuadas comparações entre os cargos de nutricionistas, técnicas em nutrição e funcionários e entre estes e as suas variáveis demográficas e funcionais.

Partindo-se de uma das definições sobre comprometimento organizacional de Mowday, Steers e Porter (1979) na qual o comprometimento se apresenta no indivíduo através de atitudes ou comportamentos que retratam um estado de identificação com uma organização e seus objetivos, desejando permanecer como um membro e com a intenção de participar e facilitar o alcance desses objetivos, pode-se observar na Tabela 2 que, no geral, para a amostra estudada, existe uma tendência ao comprometimento afetivo com o HUB (média 3,56 com desvio padrão 0,81 ). Isso porque a escala de Likert adaptada que foi utilizada variava de 1 a 5 , sendo 1 representativo da discordância total e 5, concordância total; assim, a média de 3,23 está desviada da discordância total, mas no entanto, não é representativo da concordância, mesmo que essa seja parcial.

Tabela 2 - Médias e desvios padrão dos focos do comprometimento com a organização da amostra.

\begin{tabular}{lccc}
\hline \hline COMPROMETIMENTO & N & MÉDIA & DESVIO-PADRÃO \\
\hline Comprometimento com a Organização & 46 & 3,23 & 0,60 \\
\hline Comprometimento Afetivo com a Organização & 46 & 3,56 & 0,81 \\
\hline Comprometimento Instrumental com a Organização & 46 & 3,05 & 0,65 \\
\hline Comprometimento Normativo com a Organização & 46 & 3,51 & 1,19 \\
\hline \hline
\end{tabular}

Fonte: dados da pesquisa

Para Allen e Meyer (1996), os indicadores de comprometimento afetivo se correlacionam com medidas que refletem reações de afetividade a outros focos como a satisfação no trabalho e o comprometimento com a carreira, por exemplo. Para eles o comprometimento se relaciona com aquelas experiências de trabalho que fazem o empregado sentir-se psicologicamente confortável (gerentes acessíveis, tratamentos igualitários, entre outros), que aumentam o seu sentimento de competência 
(capacidade para tarefas desafiadoras, retorno de resultados, entre outros) e que estimulam os empregados a aumentarem a sua carga de trabalho.

Analisando os focos do comprometimento organizacional através das médias e desvios-padrão encontrados, observa-se médias bastante semelhantes para todos os aspectos pesquisados e com pouca diferença entre os resultados: 3,56 para o comprometimento afetivo, 3,05 para o comprometimento instrumental e 3,51 para o comprometimento normativo. Todos esses resultados sugerem haver comprometimento em todos os aspectos, mas que esses não são os esperados segundo a escala de Likert, uma vez que para essa escala a concordância é representada pelos números 4 e 5, ou concordo parcialmente e concordo totalmente.

Tabela 3 - Freqüências das respostas, médias e desvios-padrão de cada item da escala do comprometimento organizacional referente à amostra.

\begin{tabular}{|c|c|c|c|c|c|c|c|c|}
\hline & $\begin{array}{l}\text { ASPECTOS RELACIONADOS } \grave{A} \\
\text { ORGANIZACẼO }\end{array}$ & DT & DP & $\begin{array}{l}\text { NC } \\
\text { D }\end{array}$ & CP & CT & Média & $\begin{array}{l}\text { Desvio- } \\
\text { Padrão }\end{array}$ \\
\hline$\overline{c 1}$ & $\begin{array}{l}\text { Eu seria muito feliz em dedicar o resto da } \\
\text { minha carreira a esta empresa. }\end{array}$ & 17,4 & 1919,6 & 8,7 & 30,4 & 23,9 & 3,24 & 1,463 \\
\hline 2 & $\begin{array}{l}\text { Eu realmente sinto os problemas da } \\
\text { empresa como se fossem meus }\end{array}$ & 10,9 & 15,2 & 19,6 & 39,1 & 15,2 & 3,33 & 1,230 \\
\hline 3 & $\begin{array}{l}\text { Eu me sinto pouco integrado e pouco } \\
\text { familiarizado com esta empresa }\end{array}$ & 40 & 13,3 & 15,6 & 24,4 & 6,7 & 2,44 & 1,407 \\
\hline 4 & Eu me sinto emocionalmente vinculado a & 11,1 & 4,4 & 6,7 & 42,2 & 33,3 & 3,77 & 1,350 \\
\hline \multicolumn{9}{|c|}{$\begin{array}{l}\text { Tabela } 3 \text { - Frequiências das respostas, médias e desvios-padrão de cada item da escala } \\
\text { do comprometimento organizacional referente à amostra.Continuação }\end{array}$} \\
\hline 6 & $\begin{array}{l}\text { Eu me sinto como uma pessoa "de casa" } \\
\text { nesta empresa. }\end{array}$ & 15,2 & 10,9 & 10,9 & 28,3 & 34,8 & 3,57 & $1,4 \overline{55}$ \\
\hline 7 & $\begin{array}{l}\text { Na situação atual, ficar nesta empresa é na } \\
\text { realidade um desejo mais do que uma } \\
\text { necessidade }\end{array}$ & 30,4 & 19,6 & 13 & 19,6 & 17,4 & 2,74 & 1,512 \\
\hline 8 & $\begin{array}{l}\text { Mesmo que eu quisesse, seria muito difícil } \\
\text { para eu deixar esta empresa agora. }\end{array}$ & 19,6 & 6,5 & 10,9 & 26,1 & 37 & 3,54 & 1,531 \\
\hline 9 & $\begin{array}{l}\text { Se eu decidisse deixar essa empresa agora, } \\
\text { minha vida ficaria bastante desestruturada }\end{array}$ & 8,7 & 13 & 15,2 & 23,9 & 39,1 & 3,72 & 1,344 \\
\hline 10 & $\begin{array}{l}\text { Eu acho que teria muitas alternativas de } \\
\text { trabalho se deixasse essa empresa }\end{array}$ & 22,2 & 22,2 & 26,7 & 28,9 & 0 & 2,62 & 1,134 \\
\hline 11 & $\begin{array}{l}\text { Se eu já não tivesse me dedicado tanto a } \\
\text { esta empresa, eu poderia trabalhar num } \\
\text { outro lugar. }\end{array}$ & 28,9 & 13,3 & 20 & 17,8 & 20 & 2,87 & 1,517 \\
\hline 12 & $\begin{array}{l}\text { Uma consequiência negativa de deixar essa } \\
\text { empresa seria a falta de alternativas } \\
\text { imediatas. }\end{array}$ & 8,7 & 8,7 & 26,1 & 34,8 & 21,7 & 3,52 & 1,188 \\
\hline 13 & $\begin{array}{l}\text { Trabalhar para o sucesso desta organização } \\
\text { é importante para mim. }\end{array}$ & 2,2 & 6,7 & 4,4 & 31,1 & 55,6 & 4,31 & 0,996 \\
\hline 14 & $\begin{array}{l}\text { Eu estou disposto a fazer o que me for } \\
\text { pedido pela organização. }\end{array}$ & 4,4 & 13,3 & 8,9 & 26,7 & 46,7 & 3,98 & 1,234 \\
\hline 15 & $\begin{array}{l}\text { Eu sinto que não tenho muita escolha a não } \\
\text { ser fazer o que a organização me pede. }\end{array}$ & 28,3 & 19,6 & 8,7 & 26,1 & 17,4 & 2,85 & 1,520 \\
\hline 16 & $\begin{array}{l}\text { Eu não posso arriscar fazer menos esforço } \\
\text { do que é necessário para esta organização. }\end{array}$ & 19,6 & 21,7 & 19,6 & 17,4 & 21,7 & 3,00 & 1,445 \\
\hline
\end{tabular}




\begin{tabular}{|c|c|c|c|c|c|c|c|c|}
\hline 17 & $\begin{array}{l}\text { Conversando com amigos, eu sempre me } \\
\text { refiro a minha organização como uma } \\
\text { grande instituição para a qual é ótimo } \\
\text { trabalhar. }\end{array}$ & 22,2 & 15,6 & 11,1 & 26,7 & 24,4 & 3,16 & 1,522 \\
\hline 18 & $\begin{array}{l}\text { Eu julgo que os meus valores são muito } \\
\text { similares aos valores defendidos pela } \\
\text { organização onde trabalho. }\end{array}$ & 23,9 & 10,9 & 13 & 34,8 & 17,4 & 3,11 & 1,464 \\
\hline 19 & $\begin{array}{l}\text { Eu me sinto orgulhoso dizendo às pessoas } \\
\text { que sou parte da organização onde trabalho. }\end{array}$ & 19,6 & 6,5 & 6,5 & 28,3 & 39,1 & 3,61 & 1,542 \\
\hline 20 & $\begin{array}{l}\text { A organização em que trabalho realmente } \\
\text { inspira o melhor em mim para meu } \\
\text { progresso no desempenho do trabalho. }\end{array}$ & 26,7 & 22,2 & 13,3 & 22,2 & 15,6 & 2,78 & 1,460 \\
\hline 21 & $\begin{array}{l}\text { Eu me sinto contente por ter escolhido esta } \\
\text { organização para trabalhar, } \\
\text { comparando com outras organizações que } \\
\text { considerei na época da contratação. }\end{array}$ & 8,9 & 13,3 & 22,2 & 28,9 & 26,7 & 3,51 & 1,272 \\
\hline 22 & $\begin{array}{l}\text { Eu realmente me interesso pelo destino da } \\
\text { organização onde trabalho. }\end{array}$ & 2,2 & 13,3 & 13,3 & 15,6 & 55,6 & 4,09 & 1,203 \\
\hline 23 & $\begin{array}{l}\text { Para mim, esta organização é a melhor de } \\
\text { todas as organizações para se trabalhar. }\end{array}$ & 34,1 & 20,5 & 11,4 & 18,2 & 15,9 & 2,61 & 1,513 \\
\hline 24 & $\begin{array}{l}\text { Decidir trabalhar nesta organização foi um } \\
\text { erro de minha parte. }\end{array}$ & 63 & 8,7 & 17,4 & 10,9 & 0 & 1,76 & 1,099 \\
\hline 25 & $\begin{array}{l}\text { Eu sinto pouca lealdade para com } \\
\text { organização onde trabalho. }\end{array}$ & 34,8 & 28,3 & 23,9 & 6,5 & 6,5 & 2,22 & 1,191 \\
\hline 26 & $\begin{array}{l}\text { Eu devo a essa organização fazer o que for } \\
\text { necessário para que atinja seus objetivos. }\end{array}$ & 6,5 & 6,5 & 23,9 & 32,6 & 30,4 & 3,74 & 1,163 \\
\hline 27 & $\begin{array}{l}\text { Eu sinto que tenho a obrigaçãa de trabalhar } \\
\text { bastante para esta organização. }\end{array}$ & 19,6 & 13 & 19,6 & 15,2 & 32,6 & 3,28 & 1,530 \\
\hline
\end{tabular}

Fonte: dados da pesquisa

No entanto, ao analisar os resultados relativos à frequiência das respostas separadamente por focos do comprometimento organizacional e utilizando a divisão da amostra em 3 grupos: de nutricionistas, técnicas em nutrição e funcionários, se obtém resultados mais diferenciados.

No caso do comprometimento organizacional afetivo segundo Meyer, Allen e Smith (Apêndice B), as nutricionistas apresentaram as maiores concordâncias para as questões desse comprometimento. Destacam-se as seguintes afirmativas: as nutricionistas concordaram parcialmente com Eu seria muito feliz em dedicar o resto da minha carreira a esta empresa (53,3\%), Eu realmente sinto os problemas da empresa como se fossem meus (46,7\%) e com Esta empresa tem um imenso significado pessoal para mim (60\%). Discordaram totalmente de Eu me sinto pouco integrado e pouco familiarizado com esta empresa $(73,3 \%)$ e concordaram totalmente com Eu me sinto emocionalmente vinculado a esta empresa.(60\%) e com Trabalhar para o sucesso desta organização é importante para mim (60\%). Para todas esses itens ocorre exatamente o oposto com as técnicas de nutrição, como para a primeira frase com a qual as técnicas discordaram parcialmente em 36,4\% e discordaram totalmente em 45,5\%. Comparando-se os grupos de nutricionistas, técnicos e funcionários, o de nutricionistas parece ser o 
mais comprometido afetivamente com o hospital, pois é o que apresenta maiores freqüências de concordância para essas questões.

O Apêndice $\mathrm{C}$ trata do comprometimento organizacional afetivo segundo Mowday e a Tabela 5 demonstra a comparação ente as freqüências de respostas de acordo com o cargo ocupado. Nessa há também resultado semelhante à anterior, apesar de uma das respostas ter tido uma freqüência de discordância alta: Para mim, esta organização é a melhor de todas as organizações para se trabalhar, com 40,0\% das nutricionistas tendo respondido que discordam totalmente e a resposta: A organização em que trabalho realmente inspira o melhor em mim para meu progresso no desempenho do trabalho ter apresentado uma freqüência maior para a resposta: nem concordo e nem discordo (26,7\%), as freqüências das outras respostas foram de alta concordância e, dessa forma, colaboram para a interpretação de que há entre as nutricionistas um vínculo afetivo com o HUB.

Tabela 4- Comparação das repostas mais freqüentes da escala de comprometimento afetivo (Allen,Meyer e Smith) de acordo com o cargo ocupado

\begin{tabular}{l|l|l}
\hline Item & nutricionista & técnica \\
\hline $\begin{array}{l}\text { Eu seria muito feliz em dedicar o resto da minha } \\
\text { carreira a esta empresa }\end{array}$ & $\mathrm{CP}(53,3 \%)$ & $\begin{array}{l}\mathrm{DT}(36,4 \%) \\
\mathrm{DP}(45,4 \%)\end{array}$ \\
\hline $\begin{array}{l}\text { Eu me sinto pouco integrado e pouco familiarizado } \\
\text { com esta empresa }\end{array}$ & $\mathrm{DT}(73,3 \%)$ & $\begin{array}{l}\mathrm{CP}(50 \%) \\
\mathrm{CT}(20 \%)\end{array}$ \\
\hline $\begin{array}{l}\text { Eu me sinto emocionalmente vinculado a esta empresa } \\
\text { Esta empresa tem um imenso significado pessoal para } \\
\text { mim }\end{array}$ & $\begin{array}{l}\mathrm{CP}(60 \%) \\
\mathrm{CT}(20 \%)\end{array}$ & $\begin{array}{l}\mathrm{DT}, \mathrm{DP}, \mathrm{CT} \\
(27,3 \%)\end{array}$ \\
\hline $\begin{array}{l}\text { Eu me sinto como uma pessoa "de casa" nesta } \\
\text { emresa }\end{array}$ & $\mathrm{CP}, \mathrm{CT}(33,3 \%)$ & $\begin{array}{l}\text { NCD,CP,CT } \\
(27.3 \%)\end{array}$ \\
\hline
\end{tabular}

Fonte: dados da pesquisa

Tabela 5- Comprometimento afetivo (Mowday) de acordo com o cargo

\begin{tabular}{l|l|l}
\hline Item & Nutricionista & Técnica \\
\hline $\begin{array}{l}\text { Conversando com amigos, eu sempre me refiro a } \\
\text { minha organização como uma grande instituição para a }\end{array}$ & $\mathrm{CP}(40 \%)$ & $\mathrm{DT}(54,5 \%)$ \\
\hline $\begin{array}{l}\text { Eu julgo que os meus valores são muito similares aos } \\
\text { valores defendidos nela organizacão onde trabalho }\end{array}$ & $\mathrm{CP}(40 \%)$ & $\mathrm{DT}(54,5 \%)$ \\
\hline $\begin{array}{l}\text { Eu me sinto orgulhoso dizendo às pessoas que sou } \\
\text { parte da organização onde trabalho }\end{array}$ & $\mathrm{CP}(40 \%)$ & $\mathrm{DT}(27,3 \%)$ \\
\hline $\begin{array}{l}\text { A organização em que trabalho realmente inspira o } \\
\text { melhor em mim para meu progresso no desempenho do }\end{array}$ & $\mathrm{NCD}, \mathrm{CP}(26,7 \%)$ & $\begin{array}{l}\mathrm{DT}(45,5 \%) \\
\mathrm{DP}(36,4 \%)\end{array}$ \\
\hline $\begin{array}{l}\text { Eu realmente me interesso pelo destino da organização } \\
\text { onde trabalho }\end{array}$ & $\mathrm{CT}(53,3 \%)$ & $\mathrm{CP}(27,3 \%)$ \\
\hline
\end{tabular}


Fonte: dados da pesquisa

Ao observar o comprometimento organizacional afetivo segundo Meyer, Allen e Smith em relação às respostas das técnicas em nutrição (Tabela 4) observa-se uma maior diversidade nas respostas. A tendência para o comprometimento organizacional afetivo encontrado entre as nutricionistas, não se repete entre as técnicas de nutrição. Este grupo apresentou respostas com frequiências maiores em extremos opostos das respostas: discordâncias e concordâncias. Por exemplo: 27,3\% discordaram parcialmente e 36,4\% concordaram parcialmente de Eu realmente sinto os problemas da empresa como se fossem meus, $27,3 \%$ discordaram parcialmente e $27,3 \%$ concordaram totalmente de Eu me sinto emocionalmente vinculado a esta empresa, 27,3\% discordaram totalmente e parcialmente e $27 \%$ 27,3\% concordaram parcialmente de Eu me sinto como uma pessoa "de casa" nesta empresa.

Também na Tabela 5 que trata do comprometimento organizacional afetivo segundo Mowday, os resultados referentes às respostas das técnicas em nutrição apresentam grande frequiência nas discordâncias. Entre elas, 54,5\% discordam totalmente e 27,3\% discordam parcialmente de Conversando com amigos, eu sempre me refiro a minha organização como uma grande instituição para a qual é ótimo trabalhar; $54,5 \%$ discordam totalmente e 18,2\% discordam parcialmente de Eu julgo que os meus valores são muito similares aos valores defendidos pela organização onde trabalho; 45,5\% discordam totalmente e $36,4 \%$ discordam parcialmente de A organização em que trabalho realmente inspira o melhor em mim para meu progresso no desempenho do trabalho; 63,6\% discordam totalmente de Para mim, esta organização é a melhor de todas as organizações para se trabalhar e $27,3 \%$ concordam totalmente e $45,5 \%$ concordam parcialmente com Eu sinto pouca lealdade para com organização onde trabalho. Essas respostas discordantes colaboram para a interpretação de que não há entre as técnicas em nutrição um vínculo afetivo com o HUB, apesar de em uma das respostas Decidir trabalhar nesta organização foi um erro de minha parte, ter apresentado resultado significativo, pois $63,6 \%$ das técnicas discordaram totalmente.

De acordo com Allen e Meyer (1996) todos os três componentes do comprometimento têm implicações diretas com o ficar ou deixar uma organização, e segundo os estudos desses autores há evidencias de que a intenção de mudar de emprego está consistentemente correlacionada com o comprometimento afetivo. Por tanto, a ausência do comprometimento afetivo com a organização pelas técnicas em nutrição tem relevância para a organização pois pode ser interpretada como uma tendência dessas funcionárias a deixarem a função. 
Já a rotatividade, segundo os mesmos autores, nas suas relações com as medidas de comprometimento organizacional, se relaciona tanto com o comprometimento afetivo como com o normativo, mas não com o instrumental. Para eles, uma das vantagens de se realizar o estudo sobre o comprometimento separando-o por seus indicadores é que, além de poder prever a rotatividade, podese também conhecer as implicações no comportamento no trabalho.

Ao analisar a freqüência das respostas sobre o comprometimento organizacional instrumental segundo Meyer, Allen e Smith (Tabela 6) observa-se uma similaridade em algumas respostas de nutricionistas e técnicas. Isso pode ser observado principalmente nas afirmativas: Na situação atual, ficar nesta empresa é na realidade um desejo mais do que uma necessidade onde $40 \%$ das nutricionistas discordaram totalmente e $20 \%$ discordaram parcialmente e $72,7 \%$ das técnicas discordaram totalmente; Se eu já não tivesse me dedicado tanto a esta empresa, eu poderia trabalhar num outro lugar com 53,3\% de discordância total e $20 \%$ de discordância parcial entre as nutricionistas e entre as técnicas $45,5 \%$ de discordância total e $9,1 \%$ de discordância parcial e Uma conseqüência negativa de deixar essa empresa seria a falta de alternativas imediatas que, entre as nutricionistas, $33,3 \%$ concordam parcialmente e $20 \%$ concordam totalmente e entre as técnicas, $45,5 \%$ concordam parcialmente e 18,2\% concordam totalmente. Nas outras questões há diferenças entre as respostas. Em Se eu decidisse deixar essa empresa agora, minha vida ficaria bastante desestruturada entre as nutricionistas não houve uma concordância ou discordância maior, enquanto que entre as técnicas 54,5\% concordaram totalmente. Já para as questões Eu sinto que não tenho muita escolha a não ser fazer o que a organização me pede e Eu não posso arriscar fazer menos esforço do que é necessário para esta organização, houve uma tendência à discordância entre as nutricionistas e uma tendência à concordância e ao nem concordo e nem discordo pelas técnicas.

Nas freqüências das respostas dessas questões nota-se uma dispersão das respostas das nutricionistas, das técnicas e dos funcionários, tanto para a discordância, quanto para a concordância. Esse resultado está visível e de acordo com o encontrado no cálculo das médias e desvios-padrão (Tabela 2) onde o comprometimento organizacional instrumental obteve média de 3,05 com desviopadrão de 0,65. Isso significa dizer que em toda a amostra o comprometimento organizacional instrumental com o HUB tem magnitude questionável como os demais resultados.

Segundo Allen e Meyer (1996), o comprometimento instrumental é considerado neutro sob o ponto de vista afetivo. Embora o empregado conheça perfeitamente os custos de deixar a organização, isto em si não gera nenhum sentimento positivo ou negativo em relação à questão da permanência. Os indicadores de comprometimento instrumental, no entanto, podem ter relação com outras medidas de atitudes no trabalho. Para os autores, o comprometimento instrumental desenvolve um reconhecimento 
por parte do empregado de que os investimentos feitos na organização (tempo, esforço, entre outros) são mais importantes do que outras possíveis alternativas de trabalho. E segundo Meyer e col. (1989) funcionários com vínculo instrumental tendem a contribuir menos, realizam menos esforço em seu trabalho. Ou seja, nesse foco o funcionário beneficia a instituição permanecendo nela, mas em contrapartida faz isso às custas de um mau desempenho.

Tabela 6- Respostas com maiores frequiências sobre comprometimento instrumental de acordo com o cargo ocupado

\begin{tabular}{l|l|l}
\hline Item & Nutricionista & Técnica \\
\hline $\begin{array}{l}\text { Na situação atual, ficar nesta empresa é na } \\
\text { realidade um desejo mais do que uma necessidade }\end{array}$ & $\begin{array}{l}\mathrm{DT}(40 \%) \\
\mathrm{DP}(20 \%)\end{array}$ & $\mathrm{DT}(72,7 \%)$ \\
\hline $\begin{array}{l}\text { Se eu já não tivesse me dedicado tanto a esta } \\
\text { empresa, eu poderia trabalhar num outro lugar }\end{array}$ & $\begin{array}{l}\mathrm{DT}(53,3 \%) \\
\mathrm{DP}(20 \%)\end{array}$ & $\mathrm{DT}(45,5 \%)$ \\
\hline $\begin{array}{l}\text { Uma conseqüência negativa de deixar essa empresa } \\
\text { seria a falta de alternativas imediatas }\end{array}$ & $\begin{array}{l}\mathrm{CP}(33,3 \%) \\
\mathrm{CT}(20 \%)\end{array}$ & $\begin{array}{l}\mathrm{CP}(45,5 \%) \\
\mathrm{CT}(18,2 \%)\end{array}$ \\
\hline $\begin{array}{l}\text { Se eu decidisse deixar essa empresa agora, minha } \\
\text { vida ficaria bastante desestruturada }\end{array}$ & $\begin{array}{l}\mathrm{DP}, \mathrm{NCD}, \mathrm{CT} \\
(26,7 \%)\end{array}$ & $\mathrm{CT}(54,5 \%)$ \\
\hline $\begin{array}{l}\text { Eu sinto que não tenho muita escolha a não ser } \\
\text { fazer o que a organização me pede }\end{array}$ & $\mathrm{DT}(60 \%)$ & $\mathrm{CP}(36,4 \%)$ \\
\hline
\end{tabular}

Fonte: dados da pesquisa

O comprometimento normativo (Tabela 7) foi observado em apenas três itens da pesquisa, assim, sua interpretação ficou um pouco prejudicada. Como este enfoque centra-se na estrutura das atitudes e no seu poder preditivo em relação ao comportamento (PEREIRA; OLIVEIRA, 2000, p.5) é possível notar através das frequiências das respostas, que parte dos funcionários acredita ter a obrigação de trabalhar bastante para o hospital e outra parte não sente essa mesma obrigação. Ainda que as repostas das nutricionistas tenham sido em sua maioria e de concordância parcial e total respectivamente às questões 8 e 26 Mesmo que eu quisesse, seria muito difícil para eu deixar esta empresa agora (26,7\% e 40\%) e Eu devo a essa organização fazer o que for necessário para que atinja seus objetivos (33,3\% e 27,3\%), indicando um comprometimento organizacional normativo, a amostra não apresentou esse resultado, pois obteve em relação ao cálculo da média um valor de 3,51 que indica comprometimento normativo não expressivo (Tabela 2). $\mathrm{O}$ valor de 1,19 no desvio padrão confirma a dispersão das respostas a esse foco do comprometimento.

Tabela 7- Freqüências das respostas sobre comprometimento organizacional normativo segundo Meyer, Allen e Smith de acordo com o cargo ocupado.

$\begin{array}{llllllll}\text { NUTRICIONISTAS } & N & \text { DT } & \text { DP } & \text { NCD } & \text { CP } & \text { CT }\end{array}$




\begin{tabular}{|c|c|c|c|c|c|c|c|}
\hline 27 & $\begin{array}{l}\text { Eu sinto que tenho a obrigação de trabalhar bastante } \\
\text { para esta organização. }\end{array}$ & 15 & $26,7 \%$ & $13,3 \%$ & $13,3 \%$ & $13,3 \%$ & $33,3 \%$ \\
\hline 8 & $\begin{array}{l}\text { Mesmo que eu quisesse, seria muito difícil para eu } \\
\text { deixar esta empresa agora. }\end{array}$ & 15 & $13,3 \%$ & $13,3 \%$ & $6,7 \%$ & $26,7 \%$ & $40,0 \%$ \\
\hline \multirow[t]{2}{*}{26} & $\begin{array}{l}\text { Eu devo a essa organização fazer o que for necessário } \\
\text { para que atinja seus objetivos. }\end{array}$ & 15 & $6,7 \%$ & $13,3 \%$ & $\%$ & $33,3 \%$ & $26,7 \%$ \\
\hline & TÉCNICAS & $N$ & DT & DP & NCD & $\mathbf{C P}$ & $\mathbf{C T}$ \\
\hline 27 & $\begin{array}{l}\text { Eu sinto que tenho a obrigação de trabalhar bastante } \\
\text { para esta organização. }\end{array}$ & 11 & $27,3 \%$ & $0,0 \%$ & $27,3 \%$ & $27,3 \%$ & $18,2 \%$ \\
\hline 8 & $\begin{array}{l}\text { Mesmo que eu quisesse, seria muito difícil para eu } \\
\text { deixar esta empresa agora. }\end{array}$ & 11 & $36,4 \%$ & $9,1 \%$ & $9,1 \%$ & $0,0 \%$ & $45,5 \%$ \\
\hline 26 & $\begin{array}{l}\text { Eu devo a essa organização fazer o que for necessário } \\
\text { para que atinja seus objetivos. }\end{array}$ & 11 & $9,1 \%$ & $0,0 \%$ & $18,2 \%$ & $45,5 \%$ & $27,3 \%$ \\
\hline
\end{tabular}

Fonte: dados da pesquisa

Segundo Allen e Meyer (1996), embora o comprometimento normativo seja baseado em obrigação e não em afeto, ele pode se sobrepor, em algumas situações, com o comprometimento afetivo. Assim, espera-se que os indicadores de comprometimento normativo possam estar pouco relacionados com outras medições de afetividade (incluindo o OCQ), o que confirma os achados da presente pesquisa. Para os autores, no caso do comprometimento normativo, este se desenvolve com base nas experiências de socialização durante a infância que encoraja uma manutenção do comprometimento com o empregador. Essa visão inclui tanto a influencia familiar quanto a social. O comprometimento normativo aumenta nos casos em que o empregado tem a sensação de que está recebendo mais do que é capaz de retribuir. Nesses casos, pode haver um sentimento de obrigação, um ressentimento, que pode dispersar, mas não impedir o empregado de realizar as suas obrigações.

Após a observação da existência de diferenças no comprometimento afetivo e normativo entre técnicas e nutricionistas, torna-se necessária a lembrança de que o comportamento das pessoas nas organizações é resultado da interação complexa de diversas variáveis internas e externas. As internas são aquelas decorrentes das características da personalidade, da motivação, da atitude, ao passo que as externas decorrem do ambiente, ou seja, as características organizacionais, os objetivos, os sistemas de recompensas, as oportunidades de crescimento e de desenvolvimento pessoal e profissional (PEREIRA; OLIVEIRA, 2000).

Tabela 8 - Médias e desvios-padrão relacionados aos focos do comprometimento com a carreira da amostra.

\begin{tabular}{lccc}
\hline \hline COMPROMETIMENTO & N & MÉDIA & DESVIO-PADRÃO \\
\hline Comprometimento com a Carreira & 46 & 3,45 & 0,46 \\
\hline Comprometimento Afetivo com a Carreira & 46 & 4,03 & 0,85 \\
\hline Comprometimento Instrumental com a Carreira & 46 & 3,06 & 0,71 \\
\hline Comprometimento Normativo com a Carreira & 46 & 3,26 & 0,97 \\
\hline \hline
\end{tabular}

Fonte: dados da pesquisa 
De acordo com Blau (1985) o comprometimento com a carreira pode ser definido como as atitudes de um indivíduo para com a sua carreira ou sua profissão. Analisando a Tabela 8 onde é mostrado o valor da média de comprometimento com a carreira de 3,45 com desvio-padrão de 0,46, pode-se avaliar que a amostra não apresentou comprometimento com a carreira significativo. No entanto, ao analisar os resultados relativos à freqüência das respostas separadamente por focos do comprometimento com a carreira, revela-se que o comprometimento mais expressivo é o comprometimento afetivo com a carreira com 4,03 de média e 0,85 de desvio padrão, em comparação aos demais: comprometimento com a carreira sob os focos instrumental (3,06 média e 0,71 desvio padrão) e normativo (3,26 média e 0,97 desvio padrão). Segundo Bastos, Correa e Lira (2007, p.14) o comprometimento, tanto relacionado à organização quanto relacionado à carreira,

\footnotetext{
é mediado pelo nível em que a profissão exercida é compatível com os interesses e vocação individual e o nível em que o indivíduo encontra, na organização a que pertence e no trabalho que aí realiza, condições propícias à realização profissional .
}

Tabela 9 - Freqüências das respostas, médias e desvios-padrão de cada item da escala do comprometimento com a carreira referente à amostra.

\begin{tabular}{|c|c|c|c|c|c|c|c|c|}
\hline & ASPECTOS RELACIONADOS À CARREIRA & DT & $\mathbf{D P}$ & NCD & $\mathbf{C P}$ & CT & Média & $\begin{array}{l}\text { Desvio- } \\
\text { Padrão }\end{array}$ \\
\hline 28 & $\begin{array}{l}\text { Eu estou nesta profissão/carreira por causa de senso de } \\
\text { lealdade para com ela. }\end{array}$ & 23,9 & 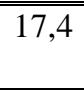 & 15,2 & 1717,4 & 26,1 & 3,04 & 1,549 \\
\hline 29 & $\begin{array}{l}\text { Eu já investi muito nesta profissão/carreira para pensar } \\
\text { em abandoná-la agora. }\end{array}$ & 26,1 & 17,4 & 8,7 & 26,1 & 21,7 & 3,00 & 1,549 \\
\hline 30 & Eu me arrependo de ter escolhido esta profissão/carreira. & 55,6 & 20 & 4,4 & 11 & 8,9 & 1,98 & 1,373 \\
\hline 31 & $\begin{array}{l}\text { Eu me sentiria culpado(a) se abandonasse minha } \\
\text { profissão/carreira agora. }\end{array}$ & 37 & 8,7 & 15,2 & 17,4 & 21,7 & 2,78 & 1,618 \\
\hline 32 & Eu não gosto de minha profissão/carreira. & 58,7 & 15,2 & 10,9 & 10,9 & 4,3 & 1,87 & 1,240 \\
\hline 33 & $\begin{array}{l}\text { Uma mudança de profissão/carreira agora iria requerer um } \\
\text { sacrifício pessoal considerável. }\end{array}$ & 26,1 & 13 & 13 & 15,2 & 32,6 & 3,15 & 1,633 \\
\hline 34 & Eu não me identifico com minha profissão/carreira. & 60 & 17,8 & 13,3 & 6,7 & 2,2 & 1,73 & 1,074 \\
\hline 35 & $\begin{array}{l}\text { Não existe nada que me impeça de mudar de profissão/ } \\
\text { carreira. }\end{array}$ & 35,6 & 13,3 & 15,6 & 17,8 & 17,8 & 2,69 & 1,550 \\
\hline 36 & $\begin{array}{l}\text { Eu não sinto Qualquer obrigação em continuar na minha } \\
\text { profissão/carreira. }\end{array}$ & 52,2 & 19,6 & 6,5 & 10,9 & 10,9 & 2,09 & 1,427 \\
\hline 37 & $\begin{array}{l}\text { Muitos aspectos de minha vida seriam prejudicados se eu } \\
\text { mudasse minha profissão/carreira agora. }\end{array}$ & 21,7 & 15,2 & 10,9 & 19,6 & 32,6 & 3,26 & 1,584 \\
\hline 38 & $\begin{array}{l}\text { Eu sinto responsabilidade em relação a minha } \\
\text { profissão/carreira, por isso continuo nela. }\end{array}$ & 13,3 & 6,7 & 6,7 & 33,3 & 40 & 3,80 & 1,392 \\
\hline
\end{tabular}




\begin{tabular}{lllllllll}
\hline \hline 39 & Eu tenho orgulho de estar nesta profissão/carreira. & 4,3 & 8,7 & 8,7 & 26,1 & 52,2 & 4,13 & 1,166 \\
\hline 40 & $\begin{array}{l}\text { Mesmo que fosse vantajoso para mim, eu não sinto que } \\
\text { seria certo abandonar minha profissão/carreira agora. }\end{array}$ & 2,2 & 28,3 & 13 & 13 & 15,2 & 2,96 & 1,665 \\
\hline 41 & $\begin{array}{l}\text { Minha profissão/carreira é importante para a imagem que } \\
\text { tenho de mim. }\end{array}$ & 11,4 & 9,1 & 9,1 & 38,6 & 31,8 & 3,70 & 1,322 \\
\hline 42 & $\begin{array}{l}\text { Mudar de carreira/profissão agora custaria muito para } \\
\text { mim. }\end{array}$ & 17,4 & 17,4 & 19,6 & 21,7 & 23,9 & 3,17 & 1,435 \\
\hline 43 & $\begin{array}{l}\text { Eu acredito que pessoas que receberam treinamento em } \\
\text { uma profissão/carreira têm a responsabilidade de exercer } \\
\text { esta profissão/carreira durante um período razoável de } \\
\text { tempo. }\end{array}$ & 19,6 & 15,2 & 23,9 & 17,4 & 23,9 & 3,11 & 1,449 \\
\hline \hline
\end{tabular}

Fonte: dados da pesquisa

Tabela 10- Frequiências das respostas sobre os aspectos relacionados ao comprometimento com a carreira de acordo com o cargo ocupado.

\begin{tabular}{|c|c|c|c|c|c|c|c|}
\hline & NUTRICIONISTA & $\overline{\mathbf{N}}$ & DT & $\overline{\mathrm{DP}}$ & NCD & $\overline{\mathbf{C P}}$ & 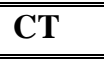 \\
\hline 28 & $\begin{array}{l}\text { Eu estou nesta profissão/carreira por causa de senso de lealdade } \\
\text { para com ela. }\end{array}$ & 15 & $13,3 \%$ & $20,0 \%$ & $6,7 \%$ & $33,3 \%$ & $26,7 \%$ \\
\hline 29 & $\begin{array}{l}\text { Eu já investi muito nesta profissão/carreira para pensar em } \\
\text { abandoná-la agora. }\end{array}$ & 15 & $26,7 \%$ & $0,0 \%$ & $20,0 \%$ & $26,7 \%$ & $26,7 \%$ \\
\hline 30 & Eu me arrependo de ter escolhido esta profissão/carreira. & 15 & $73,3 \%$ & $13,3 \%$ & $0,0 \%$ & $6,7 \%$ & $6,7 \%$ \\
\hline 31 & $\begin{array}{l}\text { Eu me sentiria culpado(a) se abandonasse minha } \\
\text { profissão/carreira agora. }\end{array}$ & 15 & $\mathbf{5 3 , 3 \%}$ & $13,3 \%$ & $6,7 \%$ & $26,7 \%$ & $0,0 \%$ \\
\hline 32 & Eu não gosto de minha profissão/carreira. & 15 & $93,3 \%$ & $6,7 \%$ & $0,0 \%$ & $0,0 \%$ & $0,0 \%$ \\
\hline 33 & $\begin{array}{l}\text { Uma mudança de profissão/carreira agora iria requerer um } \\
\text { sacrifício pessoal considerável. }\end{array}$ & 15 & $26,7 \%$ & $6,7 \%$ & $13,3 \%$ & $13,3 \%$ & $40,0 \%$ \\
\hline 34 & Eu não me identifico com minha profissão/carreira. & 15 & $86,7 \%$ & $6,7 \%$ & $6,7 \%$ & $0,0 \%$ & $0,0 \%$ \\
\hline 35 & Não existe nada que me impeça de mudar de profissão/ carreira. & 15 & $53,3 \%$ & $20,0 \%$ & $13,3 \%$ & $13,3 \%$ & $0,0 \%$ \\
\hline 36 & $\begin{array}{l}\text { Eu não sinto Qualquer obrigação em continuar na minha } \\
\text { profissão/carreira. }\end{array}$ & 15 & $66,7 \%$ & $13,3 \%$ & $0,0 \%$ & $13,3 \%$ & $6,7 \%$ \\
\hline 37 & $\begin{array}{l}\text { Muitos aspectos de minha vida seriam prejudicados se eu } \\
\text { mudasse minha profissão/carreira agora. }\end{array}$ & 15 & $20,0 \%$ & $13,3 \%$ & $6,7 \%$ & $20,0 \%$ & $40,0 \%$ \\
\hline 38 & $\begin{array}{l}\text { Eu sinto responsabilidade em relação a minha profissão/carreira, } \\
\text { por isso continuo nela. }\end{array}$ & 15 & $20,0 \%$ & $6,7 \%$ & $13,3 \%$ & $40,0 \%$ & $20,0 \%$ \\
\hline 39 & Eu tenho orgulho de estar nesta profissão/carreira. & 15 & $6,7 \%$ & $0,0 \%$ & $6,7 \%$ & $26,7 \%$ & $60,0 \%$ \\
\hline 40 & $\begin{array}{l}\text { Mesmo que fosse vantajoso para mim, eu não sinto que seria } \\
\text { certo abandonar minha profissão/carreira agora. }\end{array}$ & 15 & $13,3 \%$ & $20,0 \%$ & $20,0 \%$ & $6,7 \%$ & $40,0 \%$ \\
\hline 41 & $\begin{array}{l}\text { Minha profissão/carreira é importante para a imagem que tenho } \\
\text { de mim. }\end{array}$ & 15 & $13,3 \%$ & $0,0 \%$ & $6,7 \%$ & $53,3 \%$ & $26,7 \%$ \\
\hline 42 & Mudar de carreira/profissão agora custaria muito para mim. & 15 & $26,7 \%$ & $6,7 \%$ & $20,0 \%$ & $20,0 \%$ & $26,7 \%$ \\
\hline 43 & $\begin{array}{l}\text { Eu acredito que pessoas que receberam treinamento em uma } \\
\text { profissão/carreira têm a responsabilidade de exercer esta } \\
\text { profissão/carreira durante um período razoável de tempo. }\end{array}$ & 15 & $20,0 \%$ & $6,7 \%$ & $33,3 \%$ & $20,0 \%$ & $20,0 \%$ \\
\hline
\end{tabular}




\begin{tabular}{|c|c|c|c|c|c|c|c|}
\hline & TECNICAS DE NUTRIÇÃO & $\mathbf{N}$ & DT & DP & NCD & $\mathbf{C P}$ & CT \\
\hline 28 & $\begin{array}{l}\text { Eu estou nesta profissão/carreira por causa de senso de lealdade } \\
\text { para com ela. }\end{array}$ & 11 & $27,3 \%$ & $27,3 \%$ & $18,2 \%$ & $9,1 \%$ & $18,2 \%$ \\
\hline 29 & $\begin{array}{l}\text { Eu já investi muito nesta profissão/carreira para pensar em } \\
\text { abandoná-la agora. }\end{array}$ & 11 & $27,3 \%$ & $18,2 \%$ & $9,1 \%$ & $27,3 \%$ & $18,2 \%$ \\
\hline 30 & Eu me arrependo de ter escolhido esta profissão/carreira. & 11 & $45,5 \%$ & $27,3 \%$ & $0,0 \%$ & $27,3 \%$ & $0,0 \%$ \\
\hline 31 & $\begin{array}{l}\text { Eu me sentiria culpado(a) se abandonasse minha } \\
\text { profissão/carreira agora. }\end{array}$ & 11 & $27,3 \%$ & $9,1 \%$ & $27,3 \%$ & $0,0 \%$ & $36,4 \%$ \\
\hline 32 & Eu não gosto de minha profissão/carreira. & 11 & $54,5 \%$ & $9,1 \%$ & $18,2 \%$ & $18,2 \%$ & $0,0 \%$ \\
\hline \multirow{2}{*}{\multicolumn{5}{|c|}{$\begin{array}{l}\text { Tabela 10- Freqüências das respostas sobre os aspectos relacionados } \\
\text { comprometimento com a carreira de acordo com o cargo ocupado.Continuação }\end{array}$}} & \multirow{2}{*}{ ao $\frac{\%}{\%}$} & $18,2 \%$ & $36,4 \%$ \\
\hline & & & & & & $10,0 \%$ & $10,0 \%$ \\
\hline & TECNICAS DE NUTRIÇÃO & $\mathbf{N}$ & DT & DP & NCD & $\mathbf{C P}$ & 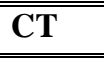 \\
\hline 35 & Não existe nada que me impeça de mudar de profissão/ carreira. & 11 & $45,5 \%$ & $9,1 \%$ & $9,1 \%$ & $27,3 \%$ & $9,1 \%$ \\
\hline 36 & $\begin{array}{l}\text { Eu não sinto Qualquer obrigação em continuar na minha } \\
\text { profissão/carreira. }\end{array}$ & 11 & $\mathbf{5 4 , 5 \%}$ & $27,3 \%$ & $0,0 \%$ & $9,1 \%$ & $9,1 \%$ \\
\hline 37 & $\begin{array}{l}\text { Muitos aspectos de minha vida seriam prejudicados se eu } \\
\text { mudasse minha profissão/carreira agora. }\end{array}$ & 11 & $18,2 \%$ & $18,2 \%$ & $18,2 \%$ & $18,2 \%$ & $27,3 \%$ \\
\hline 38 & $\begin{array}{l}\text { Eu sinto responsabilidade em relação a minha profissão/carreira, } \\
\text { por isso continuo nela. }\end{array}$ & 11 & $9,1 \%$ & $9,1 \%$ & $9,1 \%$ & $18,2 \%$ & $\mathbf{5 4 , 5 \%}$ \\
\hline 39 & Eu tenho orgulho de estar nesta profissão/carreira. & 11 & $9,1 \%$ & $18,2 \%$ & $9,1 \%$ & $27,3 \%$ & $36,4 \%$ \\
\hline 40 & $\begin{array}{l}\text { Mesmo que fosse vantajoso para mim, eu não sinto que seria } \\
\text { certo abandonar minha profissão/carreira agora. }\end{array}$ & 11 & $45,5 \%$ & $18,2 \%$ & $9,1 \%$ & $9,1 \%$ & $18,2 \%$ \\
\hline 41 & $\begin{array}{l}\text { Minha profissão/carreira é importante para a imagem que tenho } \\
\text { de mim. }\end{array}$ & 11 & $18,2 \%$ & $18,2 \%$ & $18,2 \%$ & $27,3 \%$ & $18,2 \%$ \\
\hline 42 & Mudar de carreira/profissão agora custaria muito para mim. & 11 & $0,0 \%$ & $27,3 \%$ & $27,3 \%$ & $18,2 \%$ & $27,3 \%$ \\
\hline 43 & $\begin{array}{l}\text { Eu acredito que pessoas que receberam treinamento em uma } \\
\text { profissão/carreira têm a responsabilidade de exercer esta } \\
\text { profissão/carreira durante um período razoável de tempo. }\end{array}$ & 11 & $\mathbf{5 4 , 5 \%}$ & $18,2 \%$ & $18,2 \%$ & $0,0 \%$ & $9,1 \%$ \\
\hline
\end{tabular}

Fonte: dados da pesquisa

Novamente, utilizando a divisão da amostra em 3 grupos: de nutricionistas, técnicas em nutrição e funcionários, se obtém resultados mais detalhados com relação às repostas referentes ao comprometimento com a carreira. Na Tabela 10, as nutricionistas apresentaram maiores freqüências nas respostas concordantes à existência de comprometimento com a carreira. Elas não se arrependem de terem escolhido a profissão que exercem (73\%), gostam da carreira (93,3\%), se identificam com a carreira $(86,7 \%)$, sentem obrigação em continuar a carreira $(66,7 \%)$, acreditam que existam impeditivos para mudar de carreira (53,3\%), têm orgulho de estar nessa carreira $(60 \%)$ e têm a carreira como importante para a imagem que têm de si mesmas $(53,3 \%)$.

Ainda com base na Tabela 10, as técnicas em nutrição, apesar de com freqüências menores, apresentaram respostas que também podem levar à interpretação da existência do comprometimento com a sua carreira / profissão. De acordo com suas respostas, a maioria não se arrepende em ter escolhido a carreira/profissão (45,5\%), gostam da carreira $(54,5 \%)$, sentem-se na obrigação em 
continuar na carreira $(54,5 \%)$, sentem responsabilidade em relação à carreira (54,5\%), não acham certo abandonar a carreira $(45,5 \%)$ e acreditam que têm responsabilidade em exercer a carreira em função dos custos e tempo gastos em treinamento $(54,5 \%)$.

De acordo com o resultado já relatado das médias e desvios-padrão (Tabela 8), a amostra apresenta comprometimento afetivo com a carreira. Nesse caso, é importante salientar que mais da metade $(56,6 \%)$ dos respondentes ao questionário foi de nutricionistas e técnicas (26 indivíduos em um total de 46) o que pode ter levado as respostas da amostra a uma tendência em direção às respostas das mesmas. Por tanto, com base nesse raciocínio, provavelmente o comprometimento com a carreira de nutricionistas e técnicas em nutrição seja de base afetiva.

Segundo o teste de diferença entre médias, teste t e ANOVA, (Apêndice E), há diferença significativa entre o comprometimento com a organização e o comprometimento com a carreira $(\mathrm{p}<0,01)$, com o comprometimento afetivo $(\mathrm{p}<0,01)$, com o comprometimento instrumental e com o comprometimento normativo (ambos $\mathrm{p}<0,01$ ).

Para os demais comprometimentos ocorre a correlação com $\mathrm{p}<0,01$, como para comprometimento com a carreira e com o desempenho e trabalho. Há ainda correlações significativas entre comprometimento com a organização e idade, gênero e grau de instrução; comprometimento com a carreira e estado civil e grau de instrução; comprometimento com desempenho e trabalho e gênero e grau de instrução; comprometimento afetivo e gênero e comprometimento instrumental e cargo e grau de instrução.

Considerando as variáveis demográficas e funcionais(Apêndice F), os resultados indicaram haver diferença estatisticamente significativa (com intervalo de confiança de 95\%) entre o comprometimento de acordo com o tempo na organização: os profissionais que estão de 3 a 4 anos na organização apresentam comprometimento com a organização menor do que os profissionais que estão até 2 anos, de 5 a 8 anos e há mais de 13 anos na organização. Há também diferença desse grupo com outros, em relação a comprometimento afetivo com a organização (nesse caso o comprometimento é menor em relação a todos os grupos), e o comprometimento afetivo com a carreira (com o grupo de 0 a 2 anos de organização).

Há diferença significativa (intervalo de confiação de 95\%) entre as médias dos profissionais que têm idade entre 26 e 30 e outras faixas etárias, em relação ao comprometimento com a carreira, estes profissionais tendo um comprometimento menor que os demais. Ocorre ainda diferença significativa grau de escolaridade entre $2^{\circ}$ grau incompleto e segundo grau completo quando comparado aos que têm curso superior completo, em relação ao comprometimento com a organização, comprometimento com a carreira e comprometimento instrumental com a organização (Apêndice G). Os profissionais que têm 
curso superior completo apresentam comprometimento menor que os demais. Esta diferença pode ser decorrente do fato de vários profissionais com curso superior completo desenvolvem atividades de técnico.

Em relação ao comprometimento normativo com a carreira a carreira, ele é menor para os profissionais que tem o primeiro grau completo, em relação aos que têm $2^{\circ}$ grau incompleto e superior completo(Apêndice H).

Para os cargos de nutricionista e técnico de nutrição há diferença significativa (intervalo de confiança de $95 \%$ ) entre as médias quando comparados com os demais, quanto ao comprometimento com a organização, e os comprometimentos afetivo e instrumental com a organização. Nutricionistas e técnicos apresentam comprometimento menor que os demais profissionais (Apêndice $H$ ).

De acordo com Cohen (2000) o envolvimento com o trabalho também pode ser entendido como um resultado das experiências individuais de trabalho. Quanto mais positivas forem essas experiências, maior o envolvimento com o trabalho, o que levará a atitudes positivas para com a organização e para com a ocupação. O envolvimento com o trabalho tende a ser um resultado do quanto um trabalho pode satisfazer as necessidades atuais de uma pessoa. No entanto, o envolvimento com o trabalho é, geralmente, uma crença normativa sobre o valor do trabalho na vida de uma pessoa e é mais um resultado condicionador ou socializador no passado de uma pessoa. Não foram encontradas diferenças de médias significativas de comprometimento em decorrência de gênero e estado civil

Tabela 11 - Médias e desvios-padrão relacionados ao comprometimento com o trabalho da amostra.

COMPROMETIMENTO $\quad$ N MÉDIA DESVIO-PADRAO

Comprometimento com o trabalho e o desempenho $46 \quad 3,95 \quad 0,44$

Fonte: dados da pesquisa

Tabela 12 - Frequiências das respostas, médias e desvios-padrão de cada item da escala dos aspectos relacionados ao trabalho e desempenho referentes à amostra.

\begin{tabular}{|c|c|c|c|c|c|c|c|c|}
\hline & $\begin{array}{l}\text { ASPECTOS RELACIONADOS AO TRABALHO } \\
\text { E DESEMPENHO }\end{array}$ & PT & 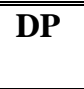 & NCD & 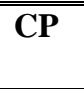 & 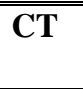 & Médias & $\begin{array}{l}\text { Desvios- } \\
\text { Padrão }\end{array}$ \\
\hline 44 & $\begin{array}{l}\text { Eu me sinto tão absorvido pelo meu trabalho que sou } \\
\text { capaz de deixar tudo o mais de lado. }\end{array}$ & 27,3 & 25 & 18,2 & 18,2 & 18 & 2,61 & 1,368 \\
\hline 45 & Eu sinto um grande prazer ao realizar o meu trabalho. & 6,5 & 10,9 & 4,3 & 30,4 & 47,8 & 4,02 & 1,256 \\
\hline 46 & $\begin{array}{l}\text { Eu me sinto orgulhoso com a qualidade do trabalho } \\
\text { que realizo. }\end{array}$ & 6,5 & 8,7 & 8,7 & 43,5 & 32,6 & 3,87 & 1,166 \\
\hline
\end{tabular}




\begin{tabular}{|c|c|c|c|c|c|c|c|c|}
\hline 47 & $\begin{array}{l}\text { Fico olhando o relógio para deixar o trabalho na hora } \\
\text { certa. }\end{array}$ & 24,4 & 111,1 & 111,1 & 26,7 & 26,7 & 3,20 & 1,561 \\
\hline 48 & $\begin{array}{l}\text { Eu sou capaz de me concentrar no meu trabalho, } \\
\text { desligando-me de outras coisas. }\end{array}$ & 6,7 & 13,3 & 4,4 & 28,9 & 46,7 & 3,96 & 1,296 \\
\hline 49 & $\begin{array}{l}\text { Eu penso no meu trabalho até mesmo quando não } \\
\text { estou no trabalho. }\end{array}$ & 15,2 & 6,5 & 8,7 & 39,1 & 30,4 & 3,63 & 1,388 \\
\hline 50 & $\begin{array}{l}\text { Sinto o dia de trabalho se arrastando como se nunca } \\
\text { fosse acabar. }\end{array}$ & 35,6 & 22,2 & 6,7 & 20 & 15,6 & 2,58 & 1,530 \\
\hline 51 & $\begin{array}{l}\text { Sentir que faço bem o meu trabalho é uma das } \\
\text { maiores recompensas que tenho. }\end{array}$ & 2,3 & 9,1 & 11,4 & 20,5 & 56,8 & 4,20 & 1,112 \\
\hline 52 & $\begin{array}{l}\text { Estou sempre me esforçando para melhorar as minhas } \\
\text { habilidades no trabalho. }\end{array}$ & 0 & 10,9 & 0 & 23,9 & 65,2 & 4,43 & 0,958 \\
\hline 53 & $\begin{array}{l}\text { Os resultados de trabalho que tenho alcançado } \\
\text { superam o que me foi atribuído. }\end{array}$ & 4,3 & 19,6 & 23,9 & 32,6 & 19,6 & 3,43 & 1,148 \\
\hline 54 & $\begin{array}{l}\text { Cumpro os prazos estabelecidos para entrega dos } \\
\text { trabalhos. }\end{array}$ & 0 & 0 & 9,1 & 34,1 & 56,8 & 4,48 & 0,664 \\
\hline 55 & $\begin{array}{l}\text { O trabalho que realizo atende aos padrões de } \\
\text { qualidade estabelecidos pela organização. }\end{array}$ & 4,4 & 0 & 6,7 & 37,8 & 51,1 & 4,31 & 0,949 \\
\hline 56 & Evito faltar ao trabalho. & 2,2 & 6,5 & 0 & 10,9 & 80,4 & 4,61 & 0,954 \\
\hline 57 & Sempre que posso me ausento do trabalho. & 76,1 & 8,7 & 8,7 & 2,2 & 4,3 & 1,50 & 1,049 \\
\hline 58 & Procuro assumir novas responsabilidades. & 6,5 & 10,9 & 21,7 & 45,7 & 15,2 & 3,52 & 1,090 \\
\hline 59 & Procuro buscar novos desafios. & 2,2 & 11,1 & 22,2 & 33,3 & 31,1 & 3,80 & 1,079 \\
\hline 60 & Assumo as responsabilidades pelo meu trabalho & 0 & 0 & 4,3 & 26,1 & 69,6 & 4,65 & 0,566 \\
\hline 61 & Sou pontual para chegar ao trabalho & 6,7 & 6,7 & 0 & 40 & 46,7 & 4,13 & 1,160 \\
\hline 62 & Sou dedicado ao meu trabalho. & 0 & 0 & 6,5 & 28,3 & 65,2 & 4,59 & 0,617 \\
\hline 63 & Dou sugestões para melhoria do trabalho. & 2,2 & 4,3 & 10,9 & 23,9 & 58,7 & 4,33 & 0,990 \\
\hline \multirow[t]{2}{*}{64} & Dou sugestão para a solução de problemas. & 2,2 & 2,2 & 10,9 & 30,4 & 54,3 & 4,33 & 0,920 \\
\hline & $\begin{array}{l}\text { ASPECTOS RELACIONADOS AO TRABALHO } \\
\text { E DESEMPENHO }\end{array}$ & DT & DP & NCD & $\mathbf{C P}$ & CT & Médias & $\begin{array}{l}\text { Desvios } \\
\text { Padrão }\end{array}$ \\
\hline & 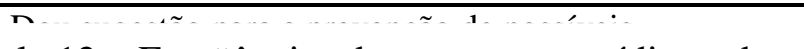 & 10 & 10 & $1+111$ & $270^{\circ}$ & 1111 & 1911 & 1,067 \\
\hline \multicolumn{8}{|c|}{$\begin{array}{l}\text { Tabela } 12 \text { - Freqüências das respostas, médias e desvios-padrão de cada item da escala } \\
\text { dos aspectos relacionados ao trabalho e desempenho referentes à amostra.Continuação }\end{array}$} & 0,634 \\
\hline 67 & Organizo meu trabalho. & 0 & 2,2 & 2,2 & 30,4 & 65,2 & 4,59 & 0,652 \\
\hline 68 & Faço o que me é solicitado. & 0 & 0 & 0 & 26,1 & 73,9 & 4,74 & 0,444 \\
\hline 69 & $\begin{array}{l}\text { Desempenho o trabalho independente das condições } \\
\text { adversas. }\end{array}$ & 2,2 & 4,3 & 6,5 & 28,3 & 58,7 & 4,37 & 0,951 \\
\hline
\end{tabular}

De acordo com a Tabela 11, a média relacionada ao comprometimento com o trabalho e desempenho é de 3,95 com desvio padrão de 0,44 que pode ser interpretada como concordante. Na tabela 12 são apresentadas as freqüências, médias e desvios-padrão por questões, nela pode-se observar que a maioria das questões apresenta média acima de 4. Baseando-se nessas informações observa-se que constam questões negativas, invertidas de sentido, que diminuem a média da amostra global, 
alterando o resultado, o que se conclui que a média é de fato ainda maior. Por tanto, na amostra podese inferir que há na amostra comprometimento com o trabalho e desempenho.

De acordo com Swailes (2002), a relação entre comprometimento e desempenho é maior ente os funcionários com menores salários. Para eles, a instabilidade financeira pode criar tanta insegurança com relação à perda do emprego, que um alto comprometimento com o trabalho e desempenho medido pode enfraquecer rapidamente após uma oferta de melhores rendimentos. Com base nessa afirmação, na presente pesquisa, os resultados das respostas para concordância em relação a um comprometimento com o trabalho e o desempenho, podem estar revelando uma insegurança relativa à perda do emprego, já que a maioria dos cargos de trabalho estudados tem baixa remuneração.

Swailes (2002) acredita que o desempenho é um conceito muito amplo, diferente do utilizado pelos pesquisadores, que se baseiam em poucos dados relativos ao domínio do desempenho e que os seus achados contradizem a crença geral de que o comprometimento e o desempenho devem se correlacionar positivamente.

Confirmando essa idéia, Bastos, Correa e Lira (1998) relatam que as mudanças nos padrões das relações de trabalho com uma redução na contratação e terceirização dos trabalhadores ampliam as incertezas e levam ao não atendimento das demandas dos funcionários de segurança e estabilidade no trabalho, levando ao enfraquecimento do vínculo com a organização e fortalecendo o vínculo com a carreira.

Tabela 13- Freqüências das respostas sobre os aspectos relacionados ao trabalho e desempenho de acordo com o cargo ocupado.

\begin{tabular}{|c|c|c|c|c|c|c|c|}
\hline & NUTRICIONISTA & $\overline{\mathbf{N}}$ & $\begin{array}{l}\text { DT } \\
\end{array}$ & 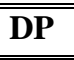 & 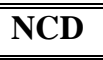 & $\overline{\mathbf{C P}}$ & 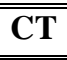 \\
\hline 44 & $\begin{array}{l}\text { Eu me sinto tão absorvido pelo meu trabalho que sou capaz de } \\
\text { deixar tudo o mais de lado. }\end{array}$ & 15 & 26,7 & 40 & 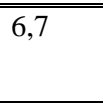 & 26,7 & 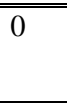 \\
\hline 45 & Eu sinto um grande prazer ao realizar o meu trabalho. & 15 & 6,7 & 6,7 & 0 & $\mathbf{3 3 , 3}$ & $\mathbf{5 3 , 3}$ \\
\hline 46 & Eu me sinto orgulhoso com a qualidade do trabalho que realizo. & 15 & 0 & 13 & 6,7 & $\mathbf{5 3 , 3}$ & 26,7 \\
\hline 47 & Fico olhando o relógio para deixar o trabalho na hora certa. & 15 & 40 & 13,3 & 13,3 & 20 & 13,3 \\
\hline 48 & $\begin{array}{l}\text { Eu sou capaz de me concentrar no meu trabalho, desligando-me } \\
\text { de outras coisas. }\end{array}$ & 15 & 20 & 6,7 & 0 & 26,7 & 46,7 \\
\hline 49 & $\begin{array}{l}\text { Eu penso no meu trabalho até mesmo quando não estou no } \\
\text { trabalho. }\end{array}$ & 15 & 20 & 13,3 & 0 & 46,7 & 20 \\
\hline 50 & $\begin{array}{l}\text { Sinto o dia de trabalho se arrastando como se nunca fosse } \\
\text { acabar. }\end{array}$ & 15 & 53,3 & 26,7 & 0 & 13,3 & 6,7 \\
\hline 51 & $\begin{array}{l}\text { Sentir que faço bem o meu trabalho é uma das maiores } \\
\text { recompensas que tenho. }\end{array}$ & 15 & 6,7 & 6,7 & 6,7 & 26,7 & 53,3 \\
\hline 52 & $\begin{array}{l}\text { Estou sempre me esforçando para melhorar as minhas } \\
\text { habilidades no trabalho. }\end{array}$ & 15 & 0 & 13,3 & 0 & 26,7 & 60 \\
\hline 53 & $\begin{array}{l}\text { Os resultados de trabalho que tenho alcançado superam o que } \\
\text { me foi atribuído. }\end{array}$ & 15 & 6,7 & 26,7 & 20 & 40 & 6,7 \\
\hline
\end{tabular}




\begin{tabular}{llllllll}
\hline \hline 54 & Cumpro os prazos estabelecidos para entrega dos trabalhos. & 15 & 0 & 0 & 6,7 & $\mathbf{4 6 , 7}$ & $\mathbf{4 6 , 7}$ \\
\hline 55 & $\begin{array}{l}\text { O trabalho que realizo atende aos padrões de qualidade } \\
\text { estabelecidos pela organização. }\end{array}$ & 15 & 0 & 6,7 & $\mathbf{4 6 , 7}$ & $\mathbf{4 6 , 7}$ \\
\hline 56 & Evito faltar ao trabalho. & 15 & 0 & 6,7 & 0 & 13,3 & $\mathbf{8 0}$ \\
\hline 57 & Sempre que posso me ausento do trabalho. & 15 & $\mathbf{9 3 , 3}$ & 0 & 0 & 0 & 6,7 \\
\hline 58 & Procuro assumir novas responsabilidades. & 15 & 6,7 & 20 & 6,7 & $\mathbf{6 0}$ & 6,7 \\
\hline 59 & Procuro buscar novos desafios. & 15 & 0 & 20 & 13,3 & $\mathbf{4 6 , 7}$ & 20 \\
\hline 60 & Assumo as responsabilidades pelo meu trabalho & 15 & 0 & 0 & 0 & 33,3 & $\mathbf{6 6 , 7}$ \\
\hline 61 & Sou pontual para chegar ao trabalho & 15 & 13,3 & 13,3 & 0 & $\mathbf{4 6 , 7}$ & $\mathbf{2 6 , 7}$ \\
\hline 62 & Sou dedicado ao meu trabalho. & 15 & 0 & 0 & 0 & $\mathbf{2 0}$ & $\mathbf{8 0}$ \\
\hline 63 & Dou sugestões para melhoria do trabalho. & 15 & 0 & 6,7 & 6,7 & $\mathbf{2 6 , 7}$ & $\mathbf{6 0}$ \\
\hline 64 & Dou sugestão para a solução de problemas. & 15 & 0 & 6,7 & 0 & $\mathbf{3 3 , 3}$ & $\mathbf{6 0}$ \\
\hline 65 & Dou sugestão para a prevenção de possíveis problemas. & 15 & 0 & 0 & 13,3 & $\mathbf{4 6 , 7}$ & $\mathbf{4 0}$ \\
\hline 66 & Dou valor ao meu trabalho. & 15 & 6,7 & 0 & 26,7 & 0 & $\mathbf{6 6 , 6}$ \\
\hline 67 & Organizo meu trabalho. & 15 & 0 & 0 & 6,7 & $\mathbf{3 3 , 3}$ & $\mathbf{6 0}$ \\
\hline $\mathbf{n}$ & $\mathbf{n}$ & 15 & 0 & $n$ & $\mathbf{2 6 , 7}$ & $\mathbf{7 2 , 3}$ \\
\hline
\end{tabular}

Tabela 13 Freqüências das respostas sobre os aspectos relacionados ao trabalho e $\begin{array}{llll}7 & \mathbf{5 3 , 3} & \mathbf{4 0}\end{array}$ desempenho de acordo com o cargo ocupado.Continuação

\begin{tabular}{llllllll}
\hline \hline 44 & Eu me sinto tão absorvido pelo meu trabalho que sou capaz de & 11 & $\mathbf{6 0}$ & $\mathbf{2 0}$ & 10 & 10 & 0
\end{tabular} deixar tudo o mais de lado.

\begin{tabular}{llllllll}
\hline 45 & Eu sinto um grande prazer ao realizar o meu trabalho. & 11 & 18,2 & 18,2 & 9,1 & $\mathbf{4 5 , 5}$ & 9,1 \\
\hline
\end{tabular}

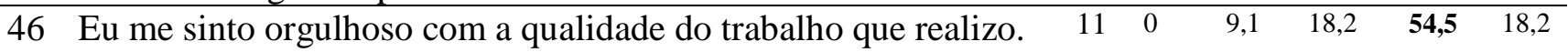

\begin{tabular}{llllllll}
\hline 47 & Fico olhando o relógio para deixar o trabalho na hora certa. & 11 & 18,2 & 0 & 9,1 & 27,3 & $\mathbf{4 5 , 5}$ \\
\hline 48 & Eu sou capaz de me concentrar no meu trabalho, desligando-me & 11 & 0 & 18,2 & 9,1 & 27,3 & $\mathbf{4 5 , 5}$
\end{tabular} de outras coisas.

49 Eu penso no meu trabalho até mesmo quando não estou no $\quad \begin{array}{llllll}11 & 18,2 & 0 & 18,2 & \mathbf{4 5 , 5} & 18,2\end{array}$ trabalho.

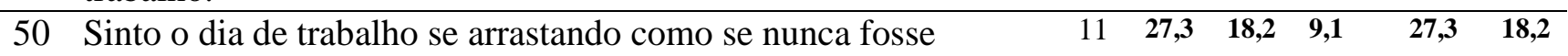
acabar.

51 Sentir que faço bem o meu trabalho é uma das maiores $\quad$\begin{tabular}{llllll}
\hline 1 & 0 & 20 & 20 & $\mathbf{3 0}$ & $\mathbf{3 0}$
\end{tabular} recompensas que tenho.

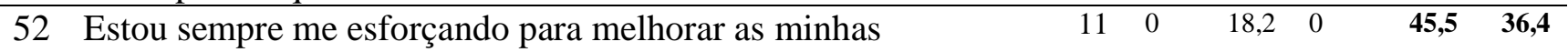
habilidades no trabalho.

\begin{tabular}{llllllll}
\hline 53 & Os resultados de trabalho que tenho alcançado superam o que & 11 & 9,1 & $\mathbf{2 7 , 3}$ & $\mathbf{2 7 , 3}$ & $\mathbf{2 7 , 3}$ & 9,1
\end{tabular} me foi atribuído.

\begin{tabular}{lllllllllll}
\hline 54 & Cumpro os prazos estabelecidos para entrega dos trabalhos. & 11 & 0 & 0 & 9,1 & 27,3 & $\mathbf{6 3 , 6}$ \\
\hline 55 & O trabalho que realizo atende aos padrões de qualidade & 11 & 0 & 0 & 9,1 & 36,4 & $\mathbf{5 4 , 5}$
\end{tabular} estabelecidos pela organização.

\begin{tabular}{llllllll}
\hline 56 & Evito faltar ao trabalho. & 11 & 0 & 0 & 0 & 0 & $\mathbf{1 0 0}$ \\
\hline 57 & Sempre que posso me ausento do trabalho. & 11 & $\mathbf{7 2 , 7}$ & $\mathbf{1 8 , 2}$ & 9,1 & 0 & 0 \\
\hline 58 & Procuro assumir novas responsabilidades. & 11 & 9,1 & 9,1 & $\mathbf{3 6 , 4}$ & $\mathbf{3 6 , 4}$ & 9,1 \\
\hline 59 & Procuro buscar novos desafios. & 11 & 9,1 & 0 & $\mathbf{3 6 , 4}$ & $\mathbf{3 6 , 4}$ & 18,2 \\
\hline 60 & Assumo as responsabilidades pelo meu trabalho & 11 & 0 & 0 & 9,1 & $\mathbf{2 7 , 3}$ & $\mathbf{6 3 , 6}$ \\
\hline 61 & Sou pontual para chegar ao trabalho & 11 & 0 & 0 & 0 & $\mathbf{5 4 , 5}$ & $\mathbf{4 5 , 5}$ \\
\hline 62 & Sou dedicado ao meu trabalho. & 11 & 0 & 0 & 18,2 & $\mathbf{6 3 , 6}$ & 18,2 \\
\hline 63 & Dou sugestões para melhoria do trabalho. & 11 & 9,1 & 0 & 9,1 & $\mathbf{3 6 , 4}$ & $\mathbf{4 5 , 5}$ \\
\hline
\end{tabular}




\begin{tabular}{llllllll}
\hline \hline 64 & Dou sugestão para a solução de problemas. & 11 & 9,1 & 0 & 9,1 & $\mathbf{5 4 , 5}$ & $\mathbf{2 7 , 3}$ \\
\hline 65 & Dou sugestão para a prevenção de possíveis problemas. & 11 & 0 & 10 & 0 & $\mathbf{7 0}$ & $\mathbf{2 0}$ \\
\hline 66 & Dou valor ao meu trabalho. & 11 & 0 & 0 & 0 & 45,5 & $\mathbf{5 4 , 5}$ \\
\hline 67 & Organizo meu trabalho. & 11 & 0 & 0 & 0 & 27,3 & $\mathbf{7 2 , 7}$ \\
\hline 68 & Faço o que me é solicitado. & 11 & 0 & 0 & 0 & 27,3 & $\mathbf{7 2 , 7}$ \\
\hline 69 & Desempenho o trabalho independente das condições adversas. & 11 & 9,1 & 0 & 9,1 & 27,3 & $\mathbf{5 4 , 5}$ \\
\hline \hline
\end{tabular}

Fonte: dados da pesquisa

Com relação ao desempenho, Allen e Meyer (1996) referem que enquanto o comprometimento afetivo e o normativo podem se correlacionar positivamente com o desempenho, o comprometimento instrumental pode tanto não ter relação, como estar negativamente correlacionado.

Ao se avaliar a amostra em grupos separadamente (nutricionistas, técnicas em nutrição e funcionários) relacionando-os ao comprometimento com o trabalho e desempenho (Tabela 13), podese perceber que os resultados apresentam-se com freqüências elevadas para as concordâncias, tanto entre as nutricionistas, quanto entre as técnicas em nutrição, confirmando o resultado da média (Tabela 11) que revelou que todo o grupo estudado (amostra) apresentou comprometimento com o trabalho e desempenho.

A relação entre comprometimento e desempenho tem sido uma das mais difíceis de elucidar. Numa pesquisa recente (SCHEIBLE, 2004), não foi possível encontrar relações significativas entre os padrões de comprometimento com desempenho. No entanto, ao analisar os dados sobre o comprometimento com a organização e carreira/ocupação separadamente, foi estabelecida correlação positiva entre comprometimento afetivo com a organização e desempenho auto-relatado. Outros estudos parecem confirmar esse achado de correlação de pequena magnitude.

No presente estudo, a amostra pode ter supervalorizado o seu desempenho auto-relatado, o que pode mascarar um real desempenho, que de fato, é impossível, por enquanto, de ser medido.

É importante ressaltar que muitos são os resultados que ainda podem ser analisados segundo a estatística. Numerosas ferramentas podem ser utilizadas para aprofundar as análises aqui apresentadas; bem é indiscutível que muitas das questões aqui apontadas poderiam ser melhor analisadas se fosse adicionada a metodologia utilizada entrevistas em profundidade, ou seja, se fosse associada a metodologia quantitativa um componente qualitativo.

Novos trabalhos sobre o comprometimento no trabalho dos funcionários do serviço de nutrição do HUB devem ser feitos levando em consideração a necessidade de aprofundamento de várias questões. 


\section{5- CONCLUSÃO}

O presente trabalho buscou identificar o grau de comprometimento com a organização, com o trabalho, com a carreira e o desempenho dos funcionários do serviço de nutrição do HUB. A partir do que foi descrito ao longo deste trabalho, pode-se concluir que há diferenças no comprometimento organizacional e em suas medidas entre os grupos de nutricionistas, técnicas em nutrição e o restante dos funcionários.

Em termos gerais, a pesquisa alcançou 46 questionários respondentes dos 60 entregues, representando cerca de $77 \%$ de retorno. A amostra foi composta na sua maioria por mulheres $(88,9 \%)$ jovens com idade média de 33 anos, metade casada (53,3\%), com nível superior de escolaridade, tendo como vínculo empregatício uma prevalência de contratados. Quase a metade da amostra está até 3 anos na instituição (44,4\%), sendo a permanência média de 6,53 anos. O cargo de maior frequiência na pesquisa foi o de nutricionista $(34,1 \%)$, que em conjunto com o cargo de técnico em nutrição perfaz $56,6 \%$ da amostra.

A amostra estudada apresentou um baixo comprometimento afetivo com a organização, o HUB com média de 3,23. Analisando as médias através dos focos do comprometimento organizacional, as médias foram baixas com pouca diferença entre os resultados: 3,56 para o comprometimento afetivo, 3,05 para o comprometimento instrumental e 3,51 para o comprometimento normativo.

$\mathrm{Na}$ análise dos resultados relativos à freqüência das respostas separadamente por focos do comprometimento organizacional e utilizando a divisão da amostra, tanto para o comprometimento organizacional afetivo segundo Meyer, Allen e Smith quanto para o comprometimento organizacional afetivo segundo Mowday, as nutricionistas apresentaram as maiores concordâncias para as questões, demonstrando a existência do comprometimento organizacional afetivo das mesmas com o HUB.

Entre as técnicas em nutrição observou-se uma maior diversidade nas respostas e os resultados referentes a essas respostas apresentaram maior frequiência nas discordâncias sobre o comprometimento organizacional afetivo tanto segundo Meyer, Allen e Smith quanto segundo Mowday. Por tanto, no estudo, inexistiu o comprometimento afetivo com a organização pelas técnicas em nutrição. Esse resultado tem relevância para a organização pois, segundo a literatura pesquisada, pode ser interpretada como uma tendência dessas funcionárias a deixarem a função. 
Sobre o comprometimento organizacional instrumental segundo Meyer, Allen e Smith observou-se uma dispersão das respostas das nutricionistas, das técnicas e dos funcionários, tanto para a discordância, quanto para a concordância. Esse resultado corrobora o encontrado no cálculo das médias e desvios-padrão onde o comprometimento organizacional instrumental obteve média de 3,05 com desvio padrão de 0,65 , podendo ser interpretado que na amostra o comprometimento organizacional instrumental com o HUB não se apresentou de forma significante. Novamente, como o maior percentual da amostra se compôs de funcionários com nível superior que, confirmando a literatura consultada, não costumam a apresentar esse foco do comprometimento.

Como foram contemplados apenas três itens sobre o comprometimento normativo na pesquisa, sua interpretação ficou um pouco prejudicada. A amostra apresentou no cálculo da média um valor de 3,51 que também indica que o comprometimento normativo se apresentou de forma pouco significativa. A presença de um valor de 1,19 no desvio-padrão nessa média retrata a dispersão dessas respostas.

O valor da média de comprometimento com a carreira de 3,45 com desvio-padrão de 0,46 demonstra que na amostra o comprometimento com a carreira também não apresentou resultado significativo. No entanto, ao analisar os resultados relativos à frequiência das respostas separadamente por focos do comprometimento com a carreira, revela-se que na amostra está presente o comprometimento afetivo com a carreira com 4,03 de média e 0,85 de desvio-padrão, enquanto que o comprometimento com a carreira sob o foco instrumental com 3,06 de média e sob o foco normativo com 3,26 já não apresentaram resultados tão significativos. As nutricionistas apresentaram as maiores frequiências nas respostas concordantes à existência de comprometimento com a carreira, bem como as técnicas em nutrição, o que podem levar à interpretação da existência do comprometimento com a sua carreira / profissão entre técnicas e nutricionistas.

O resultado da média relacionada ao comprometimento com o trabalho e desempenho de 3,95 com desvio-padrão de 0,44 na amostra direciona a existência do comprometimento com o trabalho e desempenho. Os resultados para essas respostas apresentam-se com frequiências elevadas para as concordâncias, tanto entre as nutricionistas, quanto entre as técnicas em nutrição, confirmando o resultado da média acima descrita que revelou que a amostra apresentou comprometimento com o trabalho e desempenho. No entanto, pode ter havido supervalorização do seu desempenho autorelatado, o que pode mascarar o resultado. 


\section{REFERÊNCIA:}

ALLEN, N. J.; MEYER J. P. Affective, Continuance, and Normative commitment to the organization: An examination of construct validity. Journal of vocational behavior. 49, p.252-276, 1996.

BASTOS, A.V.B. Comprometimento organizacional: um balanço dos resultados e desafios que cercam essa tradição de pesquisa. RAE, v.33,n.2.,p.52-64, mai/jun,1993.

BASTOS, A. V. B.; PINHO, A. M. COSTA, C. O. Significado do trabalho: um estudo sobre trabalhadores inseridos em organizações formais. RAE, v.35, n.6, p. 20-29, Nov/dez, 1995.

BASTOS, A. V. B.; BORGES-ANDRADE, J. E. Comprometimento com o trabalho: padrões em diferentes contextos organizacionais. RAE, v. 42, n. 2, p. 31-41, Abr./Jun, São Paulo, 2002.

BASTOS, A. V. B.; CORREA, N. C. N.; LIRA, S. B. Padrões de comprometimento com a profissão e a organização: o impacto de fatores pessoais e da natureza do trabalho. ENANPAD, p. 1-15, 1998. Disponível em: http://anpad.org.br/enanpad/1998/dwn/enanpad1998-rh-27.pdf acesso em: 6/5/2007.

BLAU, G. The measurement and prediction of career commitment. Journal of occupational psychology. Vol 58, p.277-288, 1985.

BORGES, L. O. et al. Comprometimento no trabalho e sua sustentação na cultura e no contexto organizacional. RAE-eletrônica, v. 3, n. 1, Art. 8, jan./jun. 2004.

BORGES-ANDRADE, J. E. ; PILATI, R. Comprometimentos atitudinal e comportamental: relações com suporte e imagem nas organizações. Anais do $23^{\circ}$ ENANPAD, Foz do Iguaçu, Setembro, 1999

ClUGSTON, M. ; HOWELL, J. P. ; DORFMAN, P. W. Does Cultural Socialization Predict Multiple Bases and Foci of Commitment? Journal of Management, Vol. 26, No. 1, p.5-30, 2000

COHEN, A.. The relationship between commitment forms and work outcomes: A comparison of three models. Human Relations, Volume 53(3): p.387-417, 2000

COOPER-HAKIM, A.; VISWESVARAN C. The Construct of Work Commitment: Testing an Integrative Framework. Psychological Bulletin, by the American Psychological Association. Vol. 131, No. 2, 241-259, 2005

GOULET, L. R.; SINGH, P. Career Commitment: A Reexamination and an Extension. Journal of Vocational Behavior, 61, p. 73-91. 2002

GRAPEGGIA, M. Comprometimento organizacional e qualidade no ensino: O Caso da Faculdade de Ciências Sociais Aplicadas de Cascavel - Paraná. Florianópolis, 2002, 129f. Dissertação de Mestrado - programa de Pós-graduação em Engenharia de Produção, UFSC - Universidade Federal de Santa Catarina, 2002

LAUER-LEITE, I. D. Uma análise dos tipos de comprometimento organizacional de trabalhadores de cinco setores de atividades econômicas. Psicol. Am. Lat, [online] , no.5, fev. 2006 [acesso 11 abril 2007], p.0-0. Disponível em: <http://scielo.bvs-psi.org.br/scielo.php?script=sci_arttext\&pid=S1870-

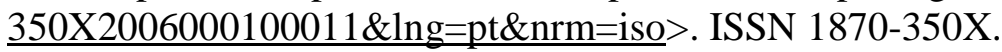


MEYER, J. P. et al. Organizational commitment and job performance: it's the nature of the commitment that counts. Journal of Applied Psychology, vol 74, nº1, p. 152-156, 1989

MINISTÉRIO DA SAÚDE: SIMONARD-LOUREIRO; H. M., SCWARZSCHILD, L. F. C. P.; TUMA, R. H. C. P.; DOMENE, S. M. A. Nutrição - Ministério da Saúde. Arquivos, p. 351-380. [acesso 5 maio de 2007]. Disponível em: http://portal.saude.gov.br/portal/arquivos/pdf/351a380_graduacao.pdf

MOTA, M. S.; FOSSÁ, M. I. T. Comunicação interna como fator gerador da cultura do comprometimento na dinâmica organizacional. Intercom - Sociedade Brasileira de Estudos Interdisciplinares da Comunicação apresentado ao XXVIII Congresso Brasileiro de Ciências da Comunicação, UERJ, set, 2005

MOWDAY, R. T.; STEERS, R. M.; PORTER, L. W. The measurement of organizational commitment. Journal of vocational behavior. Vol 14, p. 224-247, 1979.

PEREIRA, L. Z.; OLIVEIRA, R. C. M. Comprometimento organizacional:um estudo na área de administração pública municipal. Anais do 24 ENANPAD, Santa Catarina, setembro, 2000.

PEREIRA, M. Métodos empregados em epidemiologia. In: Epidemiologia teoria e prática. Guanabara Koogan. Rio de Janeiro, 2001.cap.12

REBELLO, M. A. F. R. Implantação do programa 5S para a conquista de um ambiente de qualidade na biblioteca do Hospital Universitário da Universidade de São Paulo. Revista Digital de Biblioteconomia e Ciência da Informação, Campinas, v. 3, n. 1, p. 165-182, jul./dez. 2005.

REGIS, H. P.; CALADO, S. M. R.. A Motivação para Participar do Programa da Qualidade do CEFET-PB: um Exame com Base na Teoria da Expectância. Anais da 25 ENAPAD, São Paulo, 2001

REGO, A. Comprometimento organizacional e ausência psicológica - afinal, quantas dimensões? RAE, VOL. 43, No 4, 2003

REGO, A.; SOUTO, S. Comprometimento organizacional em organizações autentizóticas: um estudo luso-brasileiro. RAE, VOL. 44, No 3, 2004

SHEIBLE, A. C. F. Comprometimento no trabalho: um estudo de caso de suas relações com desempenho e práticas de gestão. Bahia, 2004, 128f. Dissertação de Mestrado - Núcleo de pósgraduação em Administração, Universidade Federal da Bahia, 2004

SWAILES, S. Commitment to change Profiles of commitment and in-role performance. Personnel Review, Vol. 33, No. 2, pp. 187-204. 2004

TAM, Y. M.; KORCZNSKI, M.; FRENKEL, S. J. Organizational and occupational 54 nitment: knowledge workers in large corporations. Journal of Management Studies. 39:6, p.775- $/ y /, ~ L 002$

UNB. Apresentação do HUB - Hospital Universitário. portal. [acesso em 5 de maio de 2007] Disponível em: http://www.hub.unb.br/Institucional/apresentacao.htm 
VASCONCELOS, A. F. Qualidade de vida no trabalho. Caderno de pesquisas em Administração, São Paulo, v.8, n 1, Janeiro/Março, p.23. 2001 


\section{APENDICE A}

\section{PESQUISA SOBRE COMPROMETIMENTO}

Este questionário faz parte de uma pesquisa para a confecção de monografia de final de curso de PósGraduação em Gestão de Pessoas e Desenvolvimento Gerencial da Universidade de Brasília.

Não é necessário se identificar, todas as informações aqui coletadas serão tratadas de forma sigilosa, sendo utilizadas apenas para fins de projeto didático.

Gostaria de contar com sua colaboração respondendo ao questionário em anexo.

Dê suas respostas conforme as instruções, não deixando nenhuma questão sem resposta.

Grata por sua colaboração.

Analise até que ponto você concorda com as frases abaixo, em relação ao seu comprometimento com a organização, com a carreira, com seu trabalho e com seu desempenho individual, assinalando a alternativa que corresponde à sua opinião com base na seguinte escala:

\begin{tabular}{|c|c|c|c|c|c|c|c|c|c|}
\hline & 1 & 2 & 3 & 4 & & & & & \\
\hline & $\begin{array}{l}\text { Discordo } \\
\text { talmente. }\end{array}$ & $\begin{array}{c}\text { Discordo } \\
\text { parcialmente. }\end{array}$ & $\begin{array}{l}\text { Nem concordo } \\
\text { nem discordo. }\end{array}$ & $\begin{array}{c}\text { Concordo } \\
\text { parcialmente. }\end{array}$ & & & & & \\
\hline & ASPECT & RELACIONAD & Å ORGANIZA & ẤO & 1 & 2 & 3 & 4 & 5 \\
\hline 1 & Eu seria & feliz em dedica & resto da minha c & reira a esta empresa. & & & & & \\
\hline 2 & Eu realme & into os problem & la empresa como & fossem meus & & & & & \\
\hline 3 & Eu me sin & uco integrado e & uco familiarizado & om esta empresa & & & & & \\
\hline 4 & Eu me sin & nocionalmente $\mathrm{v}$ & ulado a esta emp & & & & & & \\
\hline 5 & Esta emp1 & em um imenso s & ificado pessoal $\mathrm{p}$ & a mim. & & & & & \\
\hline 6 & Eu me sin & mo uma pessoa & casa" nesta emp & esa. & & & & & \\
\hline 7 & $\begin{array}{l}\text { Na situaç } \\
\text { que uma } 1\end{array}$ & $\begin{array}{l}\text { dal, ficar nesta e } \\
\text { sidade }\end{array}$ & resa é na realidac & um desejo mais do & & & & & \\
\hline 8 & $\begin{array}{l}\text { Mesmo q } \\
\text { agora. }\end{array}$ & quisesse, seria & ito difícil para mi & deixar esta empresa & & & & & \\
\hline 9 & $\begin{array}{l}\text { Se eu dec } \\
\text { desestrute }\end{array}$ & deixar essa em & sa agora, minha & da ficaria bastante & & & & & \\
\hline 10 & $\begin{array}{l}\text { Eu acho o } \\
\text { empresa }\end{array}$ & ia muitas altern & as de trabalho $\mathrm{s}$ & leixasse essa & & & & & \\
\hline 11 & $\begin{array}{l}\text { Se eu já } \mathrm{n} \\
\text { trabalhar }\end{array}$ & $\begin{array}{l}\text { vesse me dedica } \\
\text { outro lugar. }\end{array}$ & tanto a esta empr & a, eu poderia & & & & & \\
\hline 12 & $\begin{array}{l}\text { Uma cons } \\
\text { alternativ }\end{array}$ & $\begin{array}{l}\text { ncia negativa de } \\
\text { ediatas. }\end{array}$ & xar essa empres & eria a falta de & & & & & \\
\hline 13 & Trabalhar & o sucesso desta & ganização é impc & ante para mim. & & & & & \\
\hline 14 & Eu estou & to a fazer o que & e for pedido pela & rganização. & & & & & \\
\hline 15 & $\begin{array}{l}\text { Eu sinto c } \\
\text { me pede. }\end{array}$ & o tenho muita & lha a não ser faz & que a organização & & & & & \\
\hline 16 & $\begin{array}{l}\text { Eu não } p \\
\text { organiza }\end{array}$ & riscar fazer $\mathrm{m}$ & esforço do que & lecessário para esta & & & & & \\
\hline
\end{tabular}




\begin{tabular}{|c|l|l|l|l|l|}
\hline 17 & $\begin{array}{l}\text { Conversando com amigos, eu sempre me refiro a minha organização } \\
\text { como uma grande instituição para a qual é ótimo trabalhar. }\end{array}$ & & & \\
\hline 18 & $\begin{array}{l}\text { Eu julgo que os meus valores são muito similares aos valores defendidos } \\
\text { pela organização onde trabalho. }\end{array}$ & & & \\
\hline 19 & $\begin{array}{l}\text { Eu me sinto orgulhoso dizendo às pessoas que sou parte da organização } \\
\text { onde trabalho. }\end{array}$ & & & \\
\hline
\end{tabular}

\begin{tabular}{|c|c|c|c|c|c|c|}
\hline & ASPECTOS RELACIONADOS À ORGANIZAÇÃO & 1 & 2 & 3 & 4 & 5 \\
\hline 20 & $\begin{array}{l}\text { A organização em que trabalho realmente inspira o melhor em mim para } \\
\text { meu progresso no desempenho do trabalho. }\end{array}$ & & & & & \\
\hline 21 & $\begin{array}{l}\text { Eu me sinto contente por ter escolhido esta organização para trabalhar, } \\
\text { comparando com outras organizações que considerei na época da } \\
\text { contratação. }\end{array}$ & & & & & \\
\hline 22 & Eu realmente me interesso pelo destino da organização onde trabalho. & & & & & \\
\hline 23 & $\begin{array}{l}\text { Para mim, esta organização é a melhor de todas as organizações para se } \\
\text { trabalhar. }\end{array}$ & & & & & \\
\hline 24 & Decidir trabalhar nesta organização foi um erro de minha parte. & & & & & \\
\hline 25 & Eu sinto pouca lealdade para com organização onde trabalho. & & & & & \\
\hline 26 & $\begin{array}{l}\text { Eu devo a essa organização fazer o que for necessário para que atinja } \\
\text { seus objetivos. }\end{array}$ & & & & & \\
\hline 27 & $\begin{array}{l}\text { Eu sinto que tenho a obrigação de trabalhar bastante para esta } \\
\text { organização. }\end{array}$ & & & & & \\
\hline
\end{tabular}

\begin{tabular}{|c|c|c|c|c|c|c|}
\hline & ASPECTOS RELACIONADOS À CARREIRA & 1 & 2 & 3 & 4 & 5 \\
\hline 28 & $\begin{array}{l}\text { Eu estou nesta profissão/carreira por causa de senso de lealdade para } \\
\text { com ela. }\end{array}$ & & & & & \\
\hline 29 & $\begin{array}{l}\text { Eu já investi muito nesta profissão/carreira para pensar em abandoná-la } \\
\text { agora. }\end{array}$ & & & & & \\
\hline 30 & Eu me arrependo de ter escolhido esta profissão/carreira. & & & & & \\
\hline 31 & $\begin{array}{l}\text { Eu me sentiria culpado(a) se abandonasse minha profissão/carreira } \\
\text { agora. }\end{array}$ & & & & & \\
\hline 32 & Eu não gosto de minha profissão/carreira. & & & & & \\
\hline 33 & $\begin{array}{l}\text { Uma mudança de profissão/carreira agora iria requerer um sacrifício } \\
\text { pessoal considerável. }\end{array}$ & & & & & \\
\hline 34 & Eu não me identifico com minha profissão/carreira. & & & & & \\
\hline 35 & Não existe nada que me impeça de mudar de profissão/ carreira. & & & & & \\
\hline 36 & $\begin{array}{l}\text { Eu não sinto Qualquer obrigação em continuar na minha } \\
\text { profissão/carreira. }\end{array}$ & & & & & \\
\hline 37 & $\begin{array}{l}\text { Muitos aspectos de minha vida seriam prejudicados se eu mudasse } \\
\text { minha profissão/carreira agora. }\end{array}$ & & & & & \\
\hline 38 & $\begin{array}{l}\text { Eu sinto responsabilidade em relação a minha profissão/carreira, por isso } \\
\text { continuo nela. }\end{array}$ & & & & & \\
\hline 39 & Eu tenho orgulho de estar nesta profissão/carreira. & & & & & \\
\hline
\end{tabular}




\begin{tabular}{|l|l|l|l|l|l|}
\hline 40 & $\begin{array}{l}\text { Mesmo que fosse vantajoso para mim, eu não sinto que seria certo } \\
\text { abandonar minha profissão/carreira agora. }\end{array}$ & & & \\
\hline 41 & Minha profissão/carreira é importante para a imagem que tenho de mim. & & & \\
\hline 42 & Mudar de carreira/profissão agora custaria muito para mim. & & & & \\
\hline 43 & $\begin{array}{l}\text { Eu acredito que pessoas que receberam treinamento em uma } \\
\text { profissão/carreira têm a responsabilidade de exercer esta } \\
\text { profissão/carreira durante um período razoável de tempo. }\end{array}$ & & & \\
\hline
\end{tabular}

\begin{tabular}{|c|c|c|c|c|c|c|}
\hline & $\begin{array}{l}\text { ASPECTOS RELACIONADOS AO TRABALHO E } \\
\text { DESEMPENHO }\end{array}$ & 1 & 2 & 3 & 4 & 5 \\
\hline 44 & $\begin{array}{l}\text { Eu me sinto tão absorvido pelo meu trabalho que sou capaz de deixar } \\
\text { tudo o mais de lado. }\end{array}$ & & & & & \\
\hline 45 & Eu sinto um grande prazer ao realizar o meu trabalho. & & & & & \\
\hline 46 & Eu me sinto orgulhoso com a qualidade do trabalho que realizo. & & & & & \\
\hline 47 & Fico olhando o relógio para deixar o trabalho na hora certa. & & & & & \\
\hline 48 & $\begin{array}{l}\text { Eu sou capaz de me concentrar no meu trabalho, desligando-me de } \\
\text { outras coisas. }\end{array}$ & & & & & \\
\hline 49 & Eu penso no meu trabalho até mesmo quando não estou no trabalho. & & & & & \\
\hline 50 & Sinto o dia de trabalho se arrastando como se nunca fosse acabar. & & & & & \\
\hline 51 & $\begin{array}{l}\text { Sentir que faço bem o meu trabalho é uma das maiores recompensas que } \\
\text { tenho. }\end{array}$ & & & & & \\
\hline 52 & $\begin{array}{l}\text { Estou sempre me esforçando para melhorar as minhas habilidades no } \\
\text { trabalho. }\end{array}$ & & & & & \\
\hline 53 & $\begin{array}{l}\text { Os resultados de trabalho que tenho alcançado superam o que me foi } \\
\text { atribuído. }\end{array}$ & & & & & \\
\hline 54 & Cumpro os prazos estabelecidos para entrega dos trabalhos. & & & & & \\
\hline 55 & $\begin{array}{l}\text { O trabalho que realizo atende aos padrões de qualidade estabelecidos } \\
\text { pela organização. }\end{array}$ & & & & & \\
\hline 56 & Evito faltar ao trabalho. & & & & & \\
\hline 57 & Sempre que posso me ausento do trabalho. & & & & & \\
\hline 58 & Procuro assumir novas responsabilidades. & & & & & \\
\hline 59 & Procuro buscar novos desafios. & & & & & \\
\hline 60 & Assumo as responsabilidades pelo meu trabalho & & & & & \\
\hline 61 & Sou pontual para chegar ao trabalho & & & & & \\
\hline 62 & Sou dedicado ao meu trabalho. & & & & & \\
\hline 63 & Dou sugestões para melhoria do trabalho. & & & & & \\
\hline 64 & Dou sugestão para a solução de problemas. & & & & & \\
\hline 65 & Dou sugestão para a prevenção de possíveis problemas. & & & & & \\
\hline
\end{tabular}




\begin{tabular}{|l|l|l|l|l|l|}
\hline 66 & Dou valor ao meu trabalho. & & & & \\
\hline 67 & Organizo meu trabalho. & & & & \\
\hline 68 & Faço o que me é solicitado. & & & & \\
\hline 69 & Desempenho o trabalho independente das condições adversas. & & & & \\
\hline
\end{tabular}

DADOS DEMOGRÁFICOS E FUNCIONAIS:

1 - Sexo:

( )Masculino

( )Feminino

2 - Idade: anos

3 - Estado civil: ( ) Solteiro

( ) Casado

( )Separado ou divorciado

( ) Viúvo ( )a)

( )Outros:

4 - Qual é seu grau de instrução?

( ) $1^{\circ}$ grau incompleto

( ) $1^{\circ}$ grau completo

( ) $2^{\circ}$ grau incompleto

( ) $2^{\circ}$ grau completo

( )Superior completo - em

5 - Há quanto tempo você trabalha para esta organização? anos.

6 - Qual o cargo ocupado:

7 - Qual o vínculo com a organização?

( ) contratado / terceirizado

( ) concursado / servidor público 


\section{APÊNDICE B}

Freqüências das respostas sobre comprometimento organizacional afetivo segundo Meyer, Allen e Smith de acordo com o cargo ocupado.

\begin{tabular}{|c|c|c|c|c|c|c|c|}
\hline & NUTRICIONISTAS & $\bar{N}$ & DT & $\overline{\mathbf{D P}}$ & NCD & $\mathbf{C P}$ & CT \\
\hline 1 & $\begin{array}{l}\text { Eu seria muito feliz em dedicar o resto da minha } \\
\text { carreira a esta empresa. }\end{array}$ & 15 & $20,0 \%$ & $0,0 \%$ & $13,3 \%$ & $53,3 \%$ & $13,3 \%$ \\
\hline 2 & $\begin{array}{l}\text { Eu realmente sinto os problemas da empresa como se } \\
\text { fossem meus }\end{array}$ & 15 & $13,3 \%$ & $20,0 \%$ & $13,3 \%$ & $46,7 \%$ & $6,7 \%$ \\
\hline 3 & $\begin{array}{l}\text { Eu me sinto pouco integrado e pouco familiarizado com } \\
\text { esta empresa }\end{array}$ & 15 & $73,3 \%$ & $20,0 \%$ & $6,7 \%$ & $0,0 \%$ & $0,0 \%$ \\
\hline 4 & Eu me sinto emocionalmente vinculado a esta empresa. & 15 & $0,0 \%$ & $0,0 \%$ & $6,7 \%$ & $6,7 \%$ & $60,0 \%$ \\
\hline 5 & $\begin{array}{l}\text { Esta empresa tem um imenso significado pessoal para } \\
\text { mim. }\end{array}$ & 15 & $13,3 \%$ & $6,7 \%$ & $0,0 \%$ & $60,0 \%$ & $20,0 \%$ \\
\hline 6 & Eu me sinto como uma pessoa "de casa" nesta empresa. & 15 & $13,3 \%$ & $6,7 \%$ & $13,3 \%$ & $33,3 \%$ & $33,3 \%$ \\
\hline 13 & $\begin{array}{l}\text { Trabalhar para o sucesso desta organização é importante } \\
\text { para mim. }\end{array}$ & 15 & $0,0 \%$ & $6,7 \%$ & $6,7 \%$ & $26,7 \%$ & $60,0 \%$ \\
\hline \multirow[t]{2}{*}{14} & $\begin{array}{l}\text { Eu estou disposto a fazer o que me for pedido pela } \\
\text { organização. }\end{array}$ & 15 & $6,7 \%$ & $13,3 \%$ & $0,0 \%$ & $40,0 \%$ & $40,0 \%$ \\
\hline & TÉCNICAS & $\overline{N N}$ & $\overline{\overline{D T}}$ & $\overline{\mathbf{D P}}$ & $\overline{\mathrm{NCD}}$ & $\overline{\mathbf{C P}}$ & $\overline{\mathrm{CT}}$ \\
\hline$\overline{11}$ & $\begin{array}{l}\text { Eu seria muito feliz em dedicar o resto da minha } \\
\text { carreira a esta empresa. }\end{array}$ & 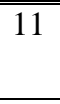 & $36,4 \%$ & $45,5 \%$ & $0,0 \%$ & $9,1 \%$ & $9,1 \%$ \\
\hline 2 & $\begin{array}{l}\text { Eu realmente sinto os problemas da empresa como se } \\
\text { fossem meus }\end{array}$ & 11 & $18,2 \%$ & $27,3 \%$ & $18,2 \%$ & $36,4 \%$ & $0,0 \%$ \\
\hline 3 & $\begin{array}{l}\text { Eu me sinto pouco integrado e pouco familiarizado com } \\
\text { esta empresa }\end{array}$ & 11 & $10,0 \%$ & $10,0 \%$ & $10,0 \%$ & $50,0 \%$ & $20,0 \%$ \\
\hline 4 & Eu me sinto emocionalmente vinculado a esta empresa. & 11 & $27,3 \%$ & $27,3 \%$ & $9,1 \%$ & $9,1 \%$ & $27,3 \%$ \\
\hline 5 & $\begin{array}{l}\text { Esta empresa tem um imenso significado pessoal para } \\
\text { mim. }\end{array}$ & 11 & $18,2 \%$ & $0,0 \%$ & $27,3 \%$ & $27,3 \%$ & $27,3 \%$ \\
\hline 6 & Eu me sinto como uma pessoa "de casa" nesta empresa. & 11 & $27,3 \%$ & $27,3 \%$ & $9,1 \%$ & $27,3 \%$ & $9,1 \%$ \\
\hline 13 & $\begin{array}{l}\text { Trabalhar para o sucesso desta organização é importante } \\
\text { para mim. }\end{array}$ & 11 & $9,1 \%$ & $9,1 \%$ & $9,1 \%$ & $54,5 \%$ & $18,2 \%$ \\
\hline 14 & $\begin{array}{l}\text { Eu estou disposto a fazer o que me for pedido pela } \\
\text { organização. }\end{array}$ & 11 & $9,1 \%$ & $18,2 \%$ & $18,2 \%$ & $18,2 \%$ & $36,4 \%$ \\
\hline
\end{tabular}

Fonte: dados da pesquisa 


\section{APÊNDICE C}

Freqüências das respostas sobre comprometimento organizacional afetivo segundo Mowday de acordo com o cargo ocupado.

\begin{tabular}{|c|c|c|c|c|c|c|c|}
\hline & NUTRICIONISTAS & 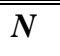 & 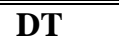 & DP & NCD & $\mathbf{C P}$ & $\mathbf{C T}$ \\
\hline 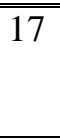 & $\begin{array}{l}\text { Conversando com amigos, eu sempre me refiro a minha } \\
\text { organização como uma grande instituição para a qual é ótimo } \\
\text { trabalhar. }\end{array}$ & 15 & $20,0 \%$ & $13,3 \%$ & $20,0 \%$ & $40,0 \%$ & $6,7 \%$ \\
\hline 18 & $\begin{array}{l}\text { Eu julgo que os meus valores são muito similares aos valores } \\
\text { defendidos pela organização onde trabalho. }\end{array}$ & 15 & $26,7 \%$ & $6,7 \%$ & $13,3 \%$ & $40,0 \%$ & $13,3 \%$ \\
\hline 19 & $\begin{array}{l}\text { Eu me sinto orgulhoso dizendo às pessoas que sou parte da } \\
\text { organização onde trabalho. }\end{array}$ & 15 & $20,0 \%$ & $0,0 \%$ & $6,7 \%$ & $40,0 \%$ & $33,3 \%$ \\
\hline 20 & $\begin{array}{l}\text { A organização em que trabalho realmente inspira o melhor } \\
\text { em mim para meu progresso no desempenho do trabalho. }\end{array}$ & 15 & $20,0 \%$ & $13,3 \%$ & $26,7 \%$ & $26,7 \%$ & $13,3 \%$ \\
\hline 21 & $\begin{array}{l}\text { Eu me sinto contente por ter escolhido esta organização para } \\
\text { trabalhar, } \\
\text { comparando com outras organizações que considerei na época } \\
\text { da contratação. }\end{array}$ & 15 & $13,3 \%$ & $13,3 \%$ & $20,0 \%$ & $26,7 \%$ & $26,7 \%$ \\
\hline 22 & $\begin{array}{l}\text { Eu realmente me interesso pelo destino da organização onde } \\
\text { trabalho. }\end{array}$ & 15 & $0,0 \%$ & $20,0 \%$ & $13,3 \%$ & $13,3 \%$ & $53,3 \%$ \\
\hline 23 & $\begin{array}{l}\text { n, esta organização é a melhor de todas as } \\
\text { ções para se trabalhar. }\end{array}$ & 15 & $40,0 \%$ & $33,3 \%$ & $6,7 \%$ & $13,3 \%$ & $6,7 \%$ \\
\hline 24 & $\begin{array}{l}\text { Decidir trabalhar nesta organização foi um erro de minha } \\
\text { parte. }\end{array}$ & 15 & $66,7 \%$ & $13,3 \%$ & $6,7 \%$ & $13,3 \%$ & \\
\hline 25 & Eu sinto pouca lealdade para com organização onde trabalho. & 15 & $53,3 \%$ & $33,3 \%$ & $0,0 \%$ & $13,3 \%$ & $0,0 \%$ \\
\hline & TÉCNICAS & $\overline{N N}$ & T & $\overline{\text { DP }}$ & 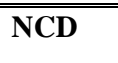 & $\overline{\mathrm{CP}}$ & $\overline{\overline{C T}}$ \\
\hline 17 & $\begin{array}{l}\text { Conversando com amigos, eu sempre me refiro a minha } \\
\text { organização como uma grande instituição para a qual é ótimo } \\
\text { trabalhar. }\end{array}$ & 11 & $54,5 \%$ & $27,3 \%$ & $9,1 \%$ & $0,0 \%$ & $9,1 \%$ \\
\hline 18 & $\begin{array}{l}\text { Eu julgo que os meus valores são muito similares aos valores } \\
\text { defendidos pela organização onde trabalho. }\end{array}$ & 11 & $54,5 \%$ & $18,2 \%$ & $9,1 \%$ & $9,1 \%$ & $9,1 \%$ \\
\hline 19 & $\begin{array}{l}\text { Eu me sinto orgulhoso dizendo às pessoas que sou parte da } \\
\text { organização onde trabalho. }\end{array}$ & 11 & $27,3 \%$ & $18,2 \%$ & $18,2 \%$ & $18,2 \%$ & $18,2 \%$ \\
\hline 20 & $\begin{array}{l}\text { A organização em que trabalho realmente inspira o melhor } \\
\text { em mim para meu progresso no desempenho do trabalho. }\end{array}$ & 11 & $45,5 \%$ & $36,4 \%$ & $0,0 \%$ & $18,2 \%$ & $0,0 \%$ \\
\hline 21 & $\begin{array}{l}\text { Eu me sinto contente por ter escolhido esta organização para } \\
\text { trabalhar, } \\
\text { comparando com outras organizações que considerei na época } \\
\text { da contratação. }\end{array}$ & 11 & $9,1 \%$ & $9,1 \%$ & $45,5 \%$ & $27,3 \%$ & $9,1 \%$ \\
\hline 22 & $\begin{array}{l}\text { Eu realmente me interesso pelo destino da organização onde } \\
\text { trabalho. }\end{array}$ & 11 & $0,0 \%$ & $0,0 \%$ & $36,4 \%$ & $27,3 \%$ & $36,4 \%$ \\
\hline 23 & $\begin{array}{l}\text { Para mim, esta organização é a melhor de todas as } \\
\text { organizações para se trabalhar. }\end{array}$ & 111 & $63,6 \%$ & $18,2 \%$ & $9,1 \%$ & $9,1 \%$ & $0,0 \%$ \\
\hline 24 & $\begin{array}{l}\text { Decidir trabalhar nesta organização foi um erro de minha } \\
\text { parte. }\end{array}$ & 11 & $63,6 \%$ & $9,1 \%$ & $18,2 \%$ & $9,1 \%$ & 0 \\
\hline 25 & Eu sinto pouca lealdade para com organização onde trabalho. & 11 & $27,3 \%$ & $45,5 \%$ & $27,3 \%$ & $0,0 \%$ & $0,0 \%$ \\
\hline
\end{tabular}

Fonte: dados da pesquisa 


\section{APÊNDICE D}

Freqüências das respostas sobre comprometimento organizacional instrumental segundo Meyer, Allen e Smith de acordo com o cargo ocupado.

\begin{tabular}{|c|c|c|c|c|c|c|c|}
\hline & NUTRICIONISTAS & $\bar{N}$ & DT & DP & NCD & $\mathbf{C P}$ & CT \\
\hline 7 & $\begin{array}{l}\text { Na situação atual, ficar nesta empresa é na realidade um } \\
\text { desejo mais do que uma necessidade }\end{array}$ & 15 & $40,0 \%$ & $20,0 \%$ & $13,3 \%$ & $20,0 \%$ & $6,7 \%$ \\
\hline 9 & $\begin{array}{l}\text { Se eu decidisse deixar essa empresa agora, minha vida } \\
\text { ficaria bastante desestruturada }\end{array}$ & 15 & $6,7 \%$ & $26,7 \%$ & $26,7 \%$ & $13,3 \%$ & $26,7 \%$ \\
\hline 10 & $\begin{array}{l}\text { Eu acho que teria muitas alternativas de trabalho se } \\
\text { deixasse essa empresa }\end{array}$ & 15 & $20,0 \%$ & $40,0 \%$ & $26,7 \%$ & $13,3 \%$ & 0 \\
\hline 11 & $\begin{array}{l}\text { Se eu já não tivesse me dedicado tanto a esta empresa, } \\
\text { eu poderia trabalhar num outro lugar. }\end{array}$ & 15 & $53,3 \%$ & $20,0 \%$ & $20,0 \%$ & $6,7 \%$ & $0,0 \%$ \\
\hline 12 & $\begin{array}{l}\text { nseqüência negativa de deixar essa empresa } \\
\text { alta de alternativas imediatas. }\end{array}$ & 15 & $13,3 \%$ & $13,3 \%$ & $20,0 \%$ & $33,3 \%$ & $20,0 \%$ \\
\hline 15 & $\begin{array}{l}\text { Eu sinto que não tenho muita escolha a não ser fazer o } \\
\text { que a organização me pede. }\end{array}$ & 15 & $60,0 \%$ & $20,0 \%$ & $13,3 \%$ & $6,7 \%$ & $0,0 \%$ \\
\hline \multirow[t]{2}{*}{16} & $\begin{array}{l}\text { menos esforço do que é } \\
\text { zação. }\end{array}$ & 15 & $40,0 \%$ & $33,3 \%$ & $0,0 \%$ & $20,0 \%$ & $6,7 \%$ \\
\hline & TÉCNICAS & 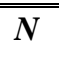 & DT & DP & NCD & $\mathbf{C P}$ & CT \\
\hline 7 & $\begin{array}{l}\mathrm{Nas} \\
\text { desej }\end{array}$ & 11 & $72,7 \%$ & $18,2 \%$ & $0,0 \%$ & $0,0 \%$ & $9,1 \%$ \\
\hline 9 & presa agora, minha vida & 1 & $9,1 \%$ & $9,1 \%$ & $9,1 \%$ & $18,2 \%$ & $54,5 \%$ \\
\hline 10 & $\begin{array}{l}\text { Eu acho que teria muitas alternativas de trabalho se } \\
\text { deixasse essa empresa }\end{array}$ & 11 & $9,1 \%$ & $27,3 \%$ & $18,2 \%$ & $45,5 \%$ & 0 \\
\hline 11 & $\begin{array}{l}\text { Se eu já não tivesse me dedicado tanto a esta empresa, } \\
\text { eu poderia trabalhar num outro lugar. }\end{array}$ & 11 & $45,5 \%$ & $9,1 \%$ & $18,2 \%$ & $9,1 \%$ & $18,2 \%$ \\
\hline 12 & $\begin{array}{l}\text { Uma conseqüência negativa de deixar essa empresa } \\
\text { seria a falta de alternativas imediatas. }\end{array}$ & 11 & $\%$ & $9,1 \%$ & $\%$ & $45,5 \%$ & $18,2 \%$ \\
\hline 15 & $\begin{array}{l}\text { Eu sinto que não tenho muita escolha a não ser fazer o } \\
\text { que a organização me pede. }\end{array}$ & 11 & $0,0 \%$ & $27,3 \%$ & $0,0 \%$ & $36,4 \%$ & $36,4 \%$ \\
\hline 16 & $\begin{array}{l}\text { Eu não posso arriscar fazer menos esforço do que é } \\
\text { necessário para esta organização. }\end{array}$ & 11 & $0,0 \%$ & $18,2 \%$ & $4,5 \%$ & $9,1 \%$ & $18,2 \%$ \\
\hline
\end{tabular}

Fonte: dados da pesquisa 
APENDICE E

Correlações: teste t e ANOVA 
Correlações: teste t e ANOVA

** Correlação é significante com 0.01 (2-tailed).

* ** Correlação é significante com 0.05 (2-tailed). 


\section{APÊNDICE F}

ANOVA e teste $\mathrm{t}$ - Tempo de organização

\begin{tabular}{|c|c|c|c|c|c|c|c|c|c|}
\hline & & \multirow[t]{2}{*}{$\mathrm{N}$} & \multirow[t]{2}{*}{ Média } & \multirow[t]{2}{*}{ Desvio } & \multirow[t]{2}{*}{ Erro } & \multicolumn{2}{|c|}{ Intervalo de confiança $95 \%$} & \multirow[t]{2}{*}{$\begin{array}{l}\text { Míni } \\
\text { mo }\end{array}$} & \multirow[t]{2}{*}{$\begin{array}{c}\text { máxim } \\
\text { o }\end{array}$} \\
\hline & & & & & & baixo & alto & & \\
\hline \multirow{6}{*}{$\begin{array}{l}\text { Comprometimento } \\
\text { com a Organização }\end{array}$} & 1,00 & 9 & 3,3057 &, 52565 &, 17522 & 2,9016 & 3,7097 & 2,64 & 3,93 \\
\hline & 2,00 & 15 & 2,7309 & ,40171 & , 10372 & 2,5084 & 2,9533 & 2,15 & 3,56 \\
\hline & 3,00 & 9 & 3,7737 &, 50325 & , 16775 & 3,3868 & 4,1605 & 2,77 & 4,30 \\
\hline & 4,00 & 7 & 3,1662 & ,38948 &, 14721 & 2,8060 & 3,5264 & 2,56 & 3,74 \\
\hline & 5,00 & 5 & 3,6799 & ,58916 & ,26348 & 2,9483 & 4,4114 & 2,70 & 4,15 \\
\hline & Total & 45 & 3,2275 & ,60834 & ,09069 & 3,0448 & 3,4103 & 2,15 & 4,30 \\
\hline \multirow{6}{*}{$\begin{array}{l}\text { Comprometimento } \\
\text { com a Carreira }\end{array}$} & 1,00 & 9 & 2,8587 & ,31554 &, 10518 & 2,6161 & 3,1012 & 2,36 & 3,38 \\
\hline & 2,00 & 15 & 2,7000 & 47727, & , 12323 & 2,4357 & 2,9643 & 2,00 & 3,50 \\
\hline & 3,00 & 9 & 3,1454 & 49015, & 16338, & 2,7686 & 3,5221 & 2,25 & 3,73 \\
\hline & 4,00 & 7 & 2,9643 & 43009, & , 16256 & 2,5665 & 3,3621 & 2,25 & 3,38 \\
\hline & 5,00 & 5 & 3,1500 & ,52403 & ,23435 & 2,4993 & 3,8007 & 2,50 & 3,69 \\
\hline & Total & 45 & 2,9119 & ,46730 & 06966 & 2,7715 & 3,0523 & 2,00 & 3,73 \\
\hline \multirow{6}{*}{$\begin{array}{l}\text { Comprometimento } \\
\text { com o trabalho e o } \\
\text { desempenho }\end{array}$} & 1,00 & 9 & 4,0242 & 41733, & 13911, & 3,7034 & 4,3450 & 3,33 & 4,50 \\
\hline & 2,00 & 15 & 3,7312 & ,35968 & 09287 & 3,5320 & 3,9304 & 3,12 & 4,23 \\
\hline & 3,00 & 9 & 4,1165 & 52917, & 17639, & 3,7097 & 4,5232 & 3,04 & 4,88 \\
\hline & 4,00 & 7 & 3,9097 & ,37211 & , 14065 & 3,5656 & 4,2539 & 3,38 & 4,42 \\
\hline & 5,00 & 5 & 4,2311 & ,47123 & ,21074 & 3,6460 & 4,8162 & 3,76 & 4,85 \\
\hline & Total & 45 & 3,9502 & ,44178 & ,06586, & 3,8174 & 4,0829 & 3,04 & 4,88 \\
\hline \multirow{6}{*}{$\begin{array}{l}\text { Comprometimento } \\
\text { Afetivo com a } \\
\text { Organização }\end{array}$} & 1,00 & 9 & 3,7054 & ,69812 & ,23271 & 3,1688 & 4,2421 & 2,47 & 4,41 \\
\hline & 2,00 & 15 & 2,8078 & 59011, & 15237 & 2,4811 & 3,1346 & 1,94 & 4,12 \\
\hline & 3,00 & 9 & 4,2745 & 69585, & ,23195 & 3,7396 & 4,8094 & 2,50 & 4,76 \\
\hline & 4,00 & 7 & 3,7342 & ,35701 & ,13494 & 3,4041 & 4,0644 & 3,12 & 4,06 \\
\hline & 5,00 & 5 & 3,9688 & 67222 & 30063 & 3,1341 & 4,8034 & 2,88 & 4,59 \\
\hline & Total & 45 & 3,5538 & ,81933 & ,12214 & 3,3076 & 3,8000 & 1,94 & 4,76 \\
\hline \multirow{6}{*}{$\begin{array}{l}\text { Comprometimento } \\
\text { Instrumental com a } \\
\text { Organização }\end{array}$} & 1,00 & 9 & 3,0794 & ,53980 & 17993, & 2,6644 & 3,4943 & 2,29 & 4,00 \\
\hline & 2,00 & 15 & 2,9143 & ,56061 & , 14475 & 2,6038 & 3,2247 & 1,57 & 3,86 \\
\hline & 3,00 & 9 & 3,2857 & ,74574 & 24858, & 2,7125 & 3,8589 & 1,86 & 4,14 \\
\hline & 4,00 & 7 & 2,7585 & 81190 & ,30687 & 2,0076 & 3,5094 & 1,71 & 4,14 \\
\hline & 5,00 & 5 & 3,2286 & ,71856 & ,32135 & 2,3364 & 4,1208 & 2,14 & 3,86 \\
\hline & Total & 45 & 3,0323 & 65235, & ,09725, & 2,8363 & 3,2283 & 1,57 & 4,14 \\
\hline \multirow{4}{*}{$\begin{array}{l}\text { Comprometimento } \\
\text { Normativo com a } \\
\text { Organização }\end{array}$} & 1,00 & 9 & 3,2222 & 1,22758 & 40919, & 2,2786 & 4,1658 & 1,00 & 5,00 \\
\hline & 2,00 & 15 & 3,2333 & 1,08342 & 27974 & 2,6334 & 3,8333 & 1,50 & 5,00 \\
\hline & 3,00 & 9 & 4,2222 & 97183 & ,32394 & 3,4752 & 4,9692 & 3,00 & 5,00 \\
\hline & 4,00 & 7 & 3,0714 & 1,59239 & 60187, & 1,5987 & 4,5441 & 1,00 & 5,00 \\
\hline
\end{tabular}


ANOVA e teste $\mathrm{t}$ - Tempo de organização. Continuação

\begin{tabular}{|c|c|c|c|c|c|c|c|c|c|}
\hline & Total & 45 & 3,5111 & 1,20835 & ,18013 & 3,1481 & 3,8741 & 1,00 & 5,00 \\
\hline \multirow{6}{*}{$\begin{array}{l}\text { Comprometimento } \\
\text { Normativo com a } \\
\text { Carreira }\end{array}$} & 1,00 & 9 & 3,5407 & ,86663 & ,28888 & 2,8746 & 4,2069 & 2,20 & 4,83 \\
\hline & 2,00 & 15 & 2,8000 & ,88685 & ,22898 & 2,3089 & 3,2911 & 1,00 & 4,33 \\
\hline & 3,00 & 9 & 3,6889 & ,71414 & ,23805 & 3,1400 & 4,2378 & 2,87 & 5,00 \\
\hline & 4,00 & 7 & 3,5000 & ,91287 & ,34503 & 2,6557 & 4,3443 & 2,33 & 4,50 \\
\hline & 5,00 & 5 & 3,2667 & 1,52115 & 68028 & 1,3779 & 5,1554 & 1,83 & 5,00 \\
\hline & Total & 45 & 3,2867 & ,96843 & , 14436 & 2,9957 & 3,5776 & 1,00 & 5,00 \\
\hline \multirow{6}{*}{$\begin{array}{l}\text { Comprometimento } \\
\text { Afetivo com a } \\
\text { Carreira }\end{array}$} & 1,00 & 9 & 4,5463 & ,48253 & , 16084 & 4,1754 & 4,9172 & 3,67 & 5,00 \\
\hline & 2,00 & 15 & 3,4500 & ,78034 & 20148 & 3,0179 & 3,8821 & 1,75 & 4,50 \\
\hline & 3,00 & 9 & 4,3241 & ,71619 & ,23873 & 3,7736 & 4,8746 & 3,25 & 5,00 \\
\hline & 4,00 & 7 & 4,3452 & ,49401 & ,18672 & 3,8884 & 4,8021 & 3,67 & 5,00 \\
\hline & 5,00 & 5 & 3,8000 & 1,31577 & ,58843 & 2,1663 & 5,4337 & 2,25 & 5,00 \\
\hline & Total & 45 & 4,0222 & ,85362 & ,12725 & 3,7658 & 4,2787 & 1,75 & 5,00 \\
\hline \multirow{6}{*}{$\begin{array}{l}\text { Comprometimento } \\
\text { Instrumental com a } \\
\text { Carreira }\end{array}$} & 1,00 & 9 & 3,0889 & ,53955 & ,17985 & 2,6742 & 3,5036 & 2,20 & 3,80 \\
\hline & 2,00 & 15 & 2,9867 & ,72690 & ,18768 & 2,5841 & 3,3892 & 2,00 & 4,00 \\
\hline & 3,00 & 9 & 3,3556 & 82327 & ,27442 & 2,7227 & 3,9884 & 1,60 & 4,00 \\
\hline & 4,00 & 7 & 3,0000 & ,77460 & 29277 & 2,2836 & 3,7164 & 1,40 & 3,80 \\
\hline & 5,00 & 5 & 3,0000 & ,58310 & ,26077 & 2,2760 & 3,7240 & 2,20 & 3,60 \\
\hline & Total & 45 & 3,0844 & 69083 & 10298 & 2,8769 & 3,2920 & 1,40 & 4,00 \\
\hline
\end{tabular}




\section{APENDICE G}

ANOVA e teste $\mathrm{t}$ - Grau de instrução

\begin{tabular}{|c|c|c|c|c|c|c|c|c|c|}
\hline & & $\mathrm{N}$ & Média & Desvio & Erro & $\begin{array}{l}\text { Interv } \\
\text { confian }\end{array}$ & $\begin{array}{l}\text { de } \\
95 \%\end{array}$ & Mínimo & $\begin{array}{l}\text { máx } \\
\text { imo }\end{array}$ \\
\hline & & & & & & baixo & alto & & \\
\hline $\begin{array}{l}\text { Comprometimento } \\
\text { com a Organização }\end{array}$ & $1^{\circ}$ grau incompleto & 3 & 3,6095 &, 72829 & ,42048 & 1,8003 & 5,4187 & 2,77 & 4,06 \\
\hline & $1^{\circ}$ grau completo & 4 & 3,4496 & ,50177 & ,25089 & 2,6512 & 4,2481 & 2,96 & 4,15 \\
\hline & $2^{\circ}$ grau incompleto & 5 & 3,7322 & ,54375 & ,24317 & 3,0570 & 4,4073 & 2,85 & 4,30 \\
\hline & $2^{\circ}$ grau completo & 11 & 3,4704 & ,64606 & ,19479 & 3,0363 & 3,9044 & 2,44 & 4,23 \\
\hline & Superior Completo & 22 & 2,8990 & ,44608 & ,09511 & 2,7012 & 3,0968 & 2,15 & 3,63 \\
\hline & Total & 45 & 3,2275 & ,60834 & ,09069 & 3,0448 & 3,4103 & 2,15 & 4,30 \\
\hline $\begin{array}{l}\text { Comprometimento } \\
\text { com a Carreira }\end{array}$ & $1^{\circ}$ grau incompleto & 3 & 3,3125 & ,33072 & ,19094 & 2,4909 & 4,1341 & 3,06 & 3,69 \\
\hline & $1^{\circ}$ grau completo & 4 & 2,6510 & ,28788 & ,14394 & 2,1930 & 3,1091 & 2,25 & 2,93 \\
\hline & $2^{\circ}$ grau incompleto & 5 & 3,2875 &, 31105 & ,13911 & 2,9013 & 3,6737 & 2,88 & 3,73 \\
\hline & $2^{\circ}$ grau completo & 11 & 3,1018 & ,44837 & ,13519 & 2,8006 & 3,4030 & 2,36 & 3,69 \\
\hline & Superior Completo & 22 & 2,7244 & ,44264 & ,09437 & 2,5282 & 2,9207 & 2,00 & 3,50 \\
\hline & Total & 45 & 2,9119 & ,46730 & ,06966 & 2,7715 & 3,0523 & 2,00 & 3,73 \\
\hline $\begin{array}{l}\text { Comprometimento } \\
\text { com o trabalho e o }\end{array}$ & $1^{\circ}$ grau incompleto & 3 & 4,1415 & ,96629 & ,55789 & 1,7412 & 6,5419 & 3,04 & 4,85 \\
\hline & $1^{\circ}$ grau completo & 4 & 4,2019 & 25391 & 12696 & 3,7979 & 4,6060 & 3,92 & 4,50 \\
\hline & $2^{\circ}$ grau incompleto & 5 & 4,2275 &, 32138 & 14373 & 3,8284 & 4,6265 & 3,71 & 4,50 \\
\hline & $2^{\circ}$ grau completo & 11 & 4,0066 & ,44920 & ,13544 & 3,7048 & 4,3084 & 3,33 & 4,88 \\
\hline & Superior Completo & 22 & 3,7871 & ,36038 &, 07683 & 3,6273 & 3,9468 & 3,12 & 4,35 \\
\hline & Total & 45 & 3,9502 & ,44178 & ,06586 & 3,8174 & 4,0829 & 3,04 & 4,88 \\
\hline $\begin{array}{l}\text { Comprometimento } \\
\text { Afetivo com a }\end{array}$ & $1^{\circ}$ grau incompleto & 3 & 3,6686 & 1,08609 & ,62706 & ,9706 & 6,3666 & 2,50 & 4,65 \\
\hline & $1^{\circ}$ grau completo & 4 & 3,7849 & ,59546 & ,29773 & 2,8374 & 4,7324 & 3,29 & 4,59 \\
\hline & $2^{\circ}$ grau incompleto & 5 & 4,1176 &, 59117 & ,26438 & 3,3836 & 4,8517 & 3,12 & 4,59 \\
\hline & $2^{\circ}$ grau completo & 11 & 3,6480 & ,91089 & ,27464 & 3,0361 & 4,2600 & 2,35 & 4,76 \\
\hline & Superior Completo & 22 & 3,3209 & ,79538 & ,16958 & 2,9682 & 3,6735 & 1,94 & 4,65 \\
\hline & Total & 45 & 3,5538 &, 81933 &, 12214 & 3,3076 & 3,8000 & 1,94 & 4,76 \\
\hline $\begin{array}{l}\text { Comprometimento } \\
\text { Instrumental com a }\end{array}$ & $1^{\circ}$ grau incompleto & 3 & 3,6667 & ,45922 & ,26513 & 2,5259 & 4,8074 & 3,14 & 4,00 \\
\hline & $1^{\circ}$ grau completo & 4 & 3,1905 &, 32297 &, 16148 & 2,6766 & 3,7044 & 2,86 & 3,57 \\
\hline & $2^{\circ}$ grau incompleto & 5 & 3,3667 &, 54596 & ,24416 & 2,6888 & 4,0446 & 2,83 & 4,14 \\
\hline & $2^{\circ}$ grau completo & 11 & 3,4286 & ,59247 & ,17864 & 3,0305 & 3,8266 & 2,14 & 4,14 \\
\hline & Superior Completo & 22 & 2,6429 & ,55020 &, 11730 & 2,3989 & 2,8868 & 1,57 & 3,71 \\
\hline & Total & 45 & 3,0323 & ,65235 & ,09725 & 2,8363 & 3,2283 & 1,57 & 4,14 \\
\hline $\begin{array}{l}\text { Comprometimento } \\
\text { Normativo com a } \\
\text { Organização }\end{array}$ & $1^{\circ}$ grau incompleto & 3 & 3,3333 & ,57735 & ,33333 & 1,8991 & 4,7676 & 3,00 & 4,00 \\
\hline
\end{tabular}




$$
\begin{array}{l|r|r|r|r|r|r|}
1^{\circ} \text { grau completo } & 4 & 3,1250 & 1,75000 & , 87500 & , 3404 & 5,9096 \\
2^{\circ} \text { grau incompleto } & 5 & 3,7000 & 1,71756 & , 76811 & 1,5674 & 5,8326
\end{array}
$$

ANOVA e teste $\mathrm{t}$-Grau de instrução.Continuação

\begin{tabular}{|c|c|c|c|c|c|c|c|c|c|}
\hline & Total & 45 & 3,5111 & 1,20835 & ,18013 & 3,1481 & 3,8741 & 1,00 & 5,00 \\
\hline \multirow{6}{*}{$\begin{array}{l}\text { Comprometimento } \\
\text { Normativo com a } \\
\text { Carreira }\end{array}$} & $1^{\circ}$ grau incompleto & 3 & 3,9444 & ,78764 & ,45474 & 1,9878 & 5,9010 & 3,33 & 4,83 \\
\hline & $1^{\circ}$ grau completo & 4 & 2,5000 & 62361 & ,31180 & 1,5077 & 3,4923 & 1,83 & 3,33 \\
\hline & $2^{\circ}$ grau incompleto & 5 & 4,4000 & 48016 & ,21473 & 3,8038 & 4,9962 & 4,00 & 5,00 \\
\hline & $2^{\circ}$ grau completo & 11 & 3,2333 & 1,06604 &, 32142 & 2,5172 & 3,9495 & 1,83 & 5,00 \\
\hline & Superior Completo & 22 & 3,1136 & 87042 &, 18557 & 2,7277 & 3,4996 & 1,00 & 4,50 \\
\hline & Total & 45 & 3,2867 & 96843 &, 14436 & 2,9957 & 3,5776 & 1,00 & 5,00 \\
\hline \multirow[t]{6}{*}{$\begin{array}{l}\text { Comprometimento } \\
\text { Afetivo com a } \\
\text { Carreira }\end{array}$} & $1^{\circ}$ grau incompleto & 3 & 4,2500 & ,90139 &, 52042 & 2,0108 & 6,4892 & 3,25 & 5,00 \\
\hline & $1^{\circ}$ grau completo & 4 & 3,6667 & 1,12423 &, 56211 & 1,8778 & 5,4556 & 2,25 & 5,00 \\
\hline & $2^{\circ}$ grau incompleto & 5 & 4,5333 & ,57312 & ,25631 & 3,8217 & 5,2450 & 3,67 & 5,00 \\
\hline & $2^{\circ}$ grau completo & 11 & 3,9470 & ,79169 & ,23870 & 3,4151 & 4,4788 & 2,50 & 5,00 \\
\hline & Superior Completo & 22 & 3,9773 & 89943 & , 19176 & 3,5785 & 4,3761 & 1,75 & 5,00 \\
\hline & Total & 45 & 4,0222 &, 85362 &, 12725 & 3,7658 & 4,2787 & 1,75 & 5,00 \\
\hline \multirow{6}{*}{$\begin{array}{l}\text { Comprometimento } \\
\text { Instrumental com a } \\
\text { Carreira }\end{array}$} & $1^{\circ}$ grau incompleto & 3 & 3,2000 & 69282 &, 40000 & 1,4789 & 4,9211 & 2,40 & 3,60 \\
\hline & $1^{\circ}$ grau completo & 4 & 2,5500 & ,80623 & ,40311 & 1,2671 & 3,8329 & 1,40 & 3,20 \\
\hline & $2^{\circ}$ grau incompleto & 5 & 3,1600 & ,47749 & ,21354 & 2,5671 & 3,7529 & 2,40 & 3,60 \\
\hline & $2^{\circ}$ grau completo & 11 & 3,4909 & ,28794 &, 08682 & 3,2975 & 3,6843 & 3,20 & 4,00 \\
\hline & Superior Completo & 22 & 2,9455 & ,78360 & 16706 & 2,5980 & 3,2929 & 1,60 & 4,00 \\
\hline & Total & 45 & 3,0844 & 69083 & 10298 & 2,8769 & 3,2920 & 1,40 & 4,00 \\
\hline
\end{tabular}


APENDICE H

ANOVA e teste $\mathrm{t}$ - Cargo

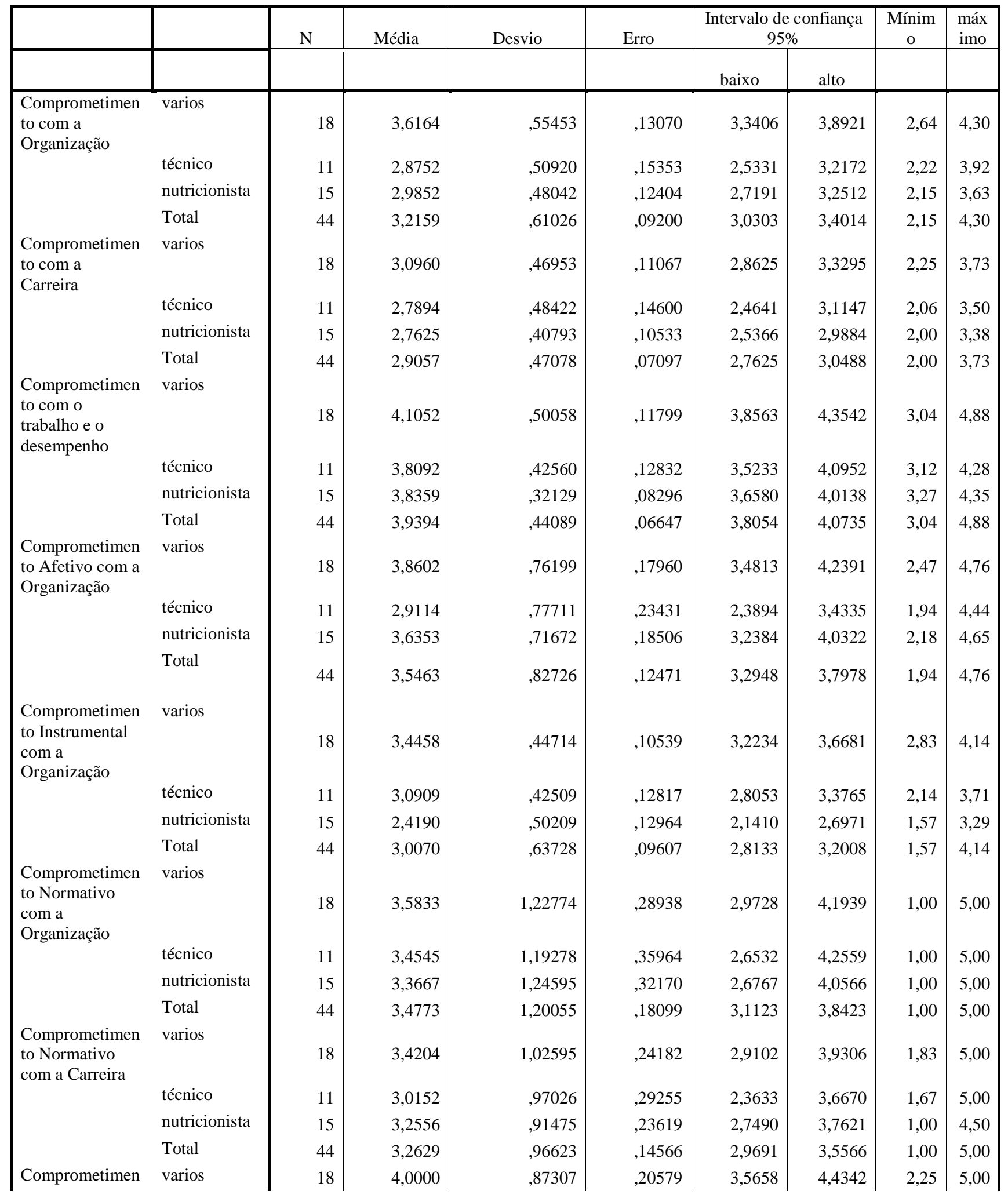


I to Afetivo com a

Cargo.Continuação

\begin{tabular}{|ll|l|l|l|l|l|r|r|r|} 
& nutricionista & 15 & 4,3333 &, 78868 &, 20364 & 3,8966 & 4,7701 & 1,75 & 5,00 \\
& Total & 44 & 4,0114 &, 86034 &, 12970 & 3,7498 & 4,2729 & 1,75 & 5,00 \\
$\begin{array}{l}\text { Comprometimen } \\
\text { to Instrumental } \\
\text { com a Carreira }\end{array}$ & varios & 18 & 3,1333 &, 63616 &, 14995 & 2,8170 & 3,4497 & 1,40 & 4,00 \\
& & & & & & & & \\
& técnico & 11 & 3,0909 &, 71757 &, 21636 & 2,6088 & 3,5730 & 2,00 & 4,00 \\
& nutricionista & 15 & 3,0133 &, 79450 &, 20514 & 2,5734 & 3,4533 & 1,60 & 4,00 \\
& Total & 44 & 3,0818 &, 69859 &, 10532 & 2,8694 & 3,2942 & 1,40 & 4,00 \\
\hline
\end{tabular}

